\title{
A Document Review to Characterize Atomic International SNAP Fuels Shipped to INEL 1966-1973
}

\author{
D. W. Kneff \\ W. E. Nagel \\ H. Pearlman \\ V. J. Schaubert \\ S. D. Wahnschaffe, Editor \\ R. E. Lords, Editor \\ Published September 1995 \\ Idaho National Engineering Laboratory \\ INEL Spent Nuclear Fuel Program \\ Lockheed Idaho Technologies Company \\ Idaho Falls, Idaho $\mathbf{8 3 4 1 5}$
}

Prepared for the

U.S. Department of Energy

Assistant Secretary for Environmental Management

Under DOE Idaho Operations Office

Contract DE-AC07-94ID13223 


\section{TABLE OF CONTENTS}

Executive Summary $\quad \ldots \ldots \ldots \ldots \ldots \ldots \ldots \ldots \ldots \ldots \ldots \ldots \ldots \ldots \ldots \ldots \ldots$

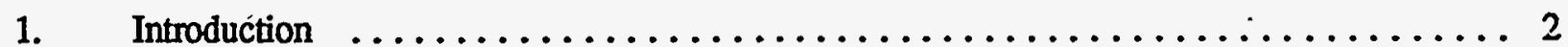

2. SNAP Fuels - General Background $\ldots \ldots \ldots \ldots \ldots \ldots \ldots \ldots \ldots \ldots \ldots \ldots \ldots \ldots \ldots$

3. Issues for the Safe Disposal of Stored SNAP Fuels $\ldots \ldots \ldots \ldots \ldots \ldots \ldots \ldots \ldots$

4. Data Gathering Approach and Report Contents $\ldots \ldots \ldots \ldots \ldots \ldots \ldots \ldots \ldots \ldots$

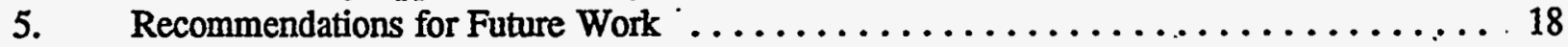

\section{SNAP REACTOR FUELS}

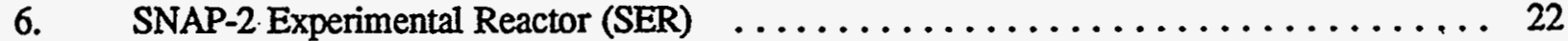

7. SNAP-2 Developmental Reactor (S2DR) $\ldots \ldots \ldots \ldots \ldots \ldots \ldots \ldots \ldots \ldots \ldots \ldots \ldots \ldots$

8. SNAP-10A Ground Test Reactor (10FS-3) $\ldots \ldots \ldots \ldots \ldots \ldots \ldots \ldots \ldots \ldots \ldots \ldots$

9. SNAP-8 Experimental Reactor (S8ER) $\ldots \ldots \ldots \ldots \ldots \ldots \ldots \ldots \ldots \ldots \ldots \ldots$

10. SNAP-8 Developmental Reactor (S8DR) $\ldots \ldots \ldots \ldots \ldots \ldots \ldots \ldots \ldots \ldots \ldots \ldots$

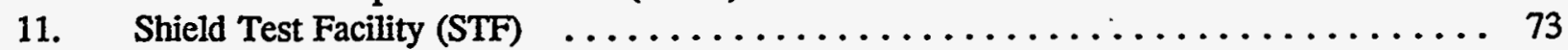

\section{IN-PILE FUEL EXPERIMENTS}

12. NAA-82-1 In-Pile Fuel Experiment $\ldots \ldots \ldots \ldots \ldots \ldots \ldots \ldots \ldots \ldots \ldots \ldots$

13. NAA-115-2 In-Pile Fuel Experiment $\ldots \ldots \ldots \ldots \ldots \ldots \ldots \ldots \ldots \ldots \ldots$

14. NAA-117-1 In-Pile Fuel Experiment $\ldots \ldots \ldots \ldots \ldots \ldots \ldots \ldots \ldots \ldots \ldots$

15. NAA-121-1,2,3,4.In-Pile Fuel Experiments $\ldots \ldots \ldots \ldots \ldots \ldots \ldots \ldots \ldots \ldots \ldots$

16. NAA-67 In-Pile Fuel Experiment $\ldots \ldots \ldots \ldots \ldots \ldots \ldots \ldots \ldots \ldots \ldots \ldots \ldots$

\section{APPENDICES}

Appendix 1: Combined Listing of Reference Documents $\ldots \ldots \ldots \ldots \ldots \ldots \ldots \ldots \ldots$

Appendix 2: Report Contributors $\ldots \ldots \ldots \ldots \ldots \ldots \ldots \ldots \ldots \ldots \ldots \ldots \ldots \ldots$

\section{DISCLAIMER}

This report was prepared as an account of work sponsored by an agency of the United States Government. Neither the United States Government nor any agency thereof, nor any of their employees, makes any warranty, express or implied, or assumes any legal liability or responsibility for the accuracy, completeness, or usefulness of any information, apparatus, product, or process disclosed, or represents that its use would not infringe privately owned rights. Reference herein to any specific commercial product, process, or service by trade name, trademark, manufacturer, or otherwise does not necessarily constitute or imply its endorsement, recommendation, or favoring by the United States Government or any agency thereof. The views and opinions of authors expressed herein do not necessarily state or reflect those of the United States Government or any agency thereof. 


\section{DISCLAIMER}

Portions of this document may be illegible in electronic image products. Images are produced from the best available original document. 


\title{
A DOCUMENT REVIEW TO CHARACTERIZE ATOMICS INTERNATIONAL SNAP FUELS SHIPPED TO INEL 1966 - 1973
}

\section{EXECUTIVE SUMMARY}

This report provides the results of a document search and review study to obtain information on the spent fuels for the following six Nuclear Auxiliary Power.(SNAP) reactor cores now stored at the Idaho National Engineering Laboratory (INEL):

SER
S2DR (SDR)
10FS-3
S8ER
S8DR
STR

\author{
SNAP-2 Experimental Reactor \\ SNAP-2 Developmental Reactor \\ SNAP-10A Ground Test Reactor \\ SNAP-8 Experimental Reactor \\ SNAP-8 Developmental Reactor \\ Shield Test Reactor
}

The report also covers documentation on SNAP fuel materials from four in-pile materials tests: NAA-821, NAA-115-2, NAA-117-1, and NAA-121. Pieces of these fuel materials are also stored at INEL as part of the SNAP fuel shipments.

The following highlights provide a summary of the results of this study:

1. We have reviewed all of the original records of irradiated fuel shipments, with independent

. verification of mass sums by computer analysis. Correlations were made with the INEL receiving

. records that were available to us. We believe we have accounted for all material involved, with only minor discrepancies.

$\therefore$ 2. . We have reviewed the Rocketdyne/ETEC documents that deal with fuel fabrication, quality assurance, operating experience, and post-irradiation hot cell evaluation, and have obtained characterization. information for all of the SNAP fuels presently stored at INEL. The -most extensive information available is for the-S8ER; S8DR, and 10FS-3 cores.

3. It has not been possible to send to -INEL "intelligible copies of all relevant fuel information" for above items 1 and 2. This is because of the nature of the documents (some hand-written and not readily reproducible) and the large volume of material.

4. SNAP fuels were origizally intended for reprocessing, and were never intended to be an acceptable waste form for a repository. It is our opinion that at least some conditioning is necessary to make them acceptable for repository disposal. Precise criteria for such waste forms are not now available, and knowledge of the present state of the fuel is very limited. It is our recommendation that further work include sampling of the fuels to establish the range of their condition, code calculations to estimate the present inventories of fission products and transuranics (if any), and.investigation of compact waste forms (such as Tailored Ceramics or Synroc) for final repository emplacement.

5. Recommendations for follow-on activities to continue the characterization of the SNAP fuels were developed during the course of the work and are included in this report. 


\section{INTRODUCTION}

\subsection{OVERVIEW}

North American Aviation's Atomics Intemational Division (AI) was under contract with the former U.S. Atomic Energy Commission for about 25 years to perform research and development work on Systems for Nuclear Auxiliary Power (SNAP). The SNAP program included both reactor and radioisotope heat sources, where the SNAP reactors were assigned even numbers and the radioisotope systems odd numbers. AI's first SNAP fuel development work was performed for radioisotope systems (Reference La51), because ${ }^{235} \mathrm{U}$ was initially considered too valuable a resource for space applications. However, with the increasing availability of fully enriched uranium, attention turned to the development of reactor systems for nuclear auxiliary power.

Atomics Intemational, which has since merged with the Rocketdyne Division of what is now the Rockwell Intemational Corporation, developed and operated six SNAP reactor systems under this program. The AI activities included fuel-element development and testing, fabrication of fuel elements for SNAP reactor. cores, SNAP reactor operation, and the post-irradiation examination and evaluation of fuel elements and test components. The objective was to develop compact, lightweight nuclear reactor heat systems that would provide long-term auxiliary power for spacecraft. The SNAP fuel materials now stored at INEL were generated under this reactor development program.

A total of five different SNAP reactors, all typical of designs for spacecraft power systems, were built and ground-tested at.AI. These five are as follows:

$\begin{array}{ll}\text { SER } & \text { SNAP-2 Experimental Reactor } \\ \text { S2DR (SDR) } & \text { SNAP-2 Developmental Reactor } \\ \text { 10FS-3 } & \text { SNAP-10A Ground Test Reactor } \\ \text { S8ER } & \text { SNAP-8 Experimental Reactor } \\ \text { S8DR } & \text { SNAP-8 Developmental Reactor }\end{array}$

The first reactor of the SNAP design was the SNAP Experimental Reactor (SER), also called the SNAP 2.Experimental Reactor. There were many changes in program direction during SNAP development, and the SNAP 2 series was followed by the SNAP 10A series of reactors. The SNAP 8 Developmental - Reactor (S8DR) was built after the 10A systems. One of the 10A systems, the SNAP 10A FS-3, was a complete reactor-based electric.generating plant which operated for more than 10,000 hours at full power under simulated space-flight conditions. A duplicate system, the 10A FS-4, was launched in April 1965 into a nominal 700 -mile polar orbit whose estimated lifetime is 3800 years. That reactor was started up by ground signal and operated entirely on passive control until it was automatically shut down, and is still in orbit. A third duplicate system, the 10A FS-5, was also tabricated but never operated, and its fuel elements were shipped to Oak Ridge National. Laboratory for disposal. Other SNAP developmental reactor cores fabricated by AI included those used for the SNAPTRAN tests at INEL.

AI also built and operated a low-power research reactor, the Shield Test Reactor (STR), in support of the SNAP program. This facility utilized SNAP Experimental Reactor (SER)-type fuel rods and was used for testing reactor components. It pre-dated all but the SER and an earlier critical facility that used SNAPtype developmental fuel materials.

- The SNAP program also included the conduct of many in-pile experiments in off-site research reactors to test fuel performance under controlled conditions. Those experiments were heavily instrumented, with 
performance measured and recorded in real time, at temperature, and under irradiation. A few of those irradiated fuel materials are also in storage at INEL, and come from the following four in-pile tests: NAA-82-1, NAA-115-2, NAA-117-1, and NAA-121. The NAA-117 fuel material has the highest bumup of the SNAP fuels stored at INEL.

All of the SNAP fuels were made by AI. This was initially a project carried out by research and development personnel, but fuel fabrication gradually evolved into a disciplined manufacturing activity. It operated with.written procedures and specifications, and was monitored by a separate quality assurance. (QA) organization. Thus the later fuel materials have significantly better QA documentation. Fuels from both the SNAP reactor cores and the in-pile experiments were examined in the Atomics Intemational Hot Laboratory (AIHL) after irradiation. They. were then packaged for shipment, stored temporarily at AI's Radioactive Materials Disposal Facility (RMDF), and shipped to. INEL. Because the SNAP fuels were $93 \%$ enriched in ${ }^{235} \mathrm{U}$, the intention was to reprocess them at ICPP and recover unburned ${ }^{235} \mathrm{U}$.

This report reviews all of the Rockwell shipments of SNAP fuels to INEL, based on our review of the original shipping and accountability records retrieved from ETEC files.' The report also references and reviews available documentation on the characterization of the fuels that has been retrieved from.the Rocketdyne Technical Information Center, AI Technical Data Center, archived AIHL records, shipping files, and other archived personal and storage files. Coverage includes all six ground reactors and those in-pile experiments for which fuels were shipped to.INEL. Some fuels were destructively examined in the AIHL, resulting in multiple fuel segments. Part of these were shipped to INEL, while others were shipped to different storage sites or disposed of as radioactive scrap.

\subsection{SNAP NOMENCLATURE}

Nomenclature used in AI publications on the SNAP reactor programs has not been consistent. This is due at least in part to the evolutionary nature of the programs. For example, the SNAP 2 program has also been referred to as SNAP II, and sometimes in the same document.

In a given reactor program, the chronological sequence went from " $E$ " for experimental (such as the SNAP-2 Experimental Reactor, SER), to ."D". for developmental (such as the SNAP-2 Developmental Reactor, S2DR), to " $F$ ". for flight: "In the designation S2DR, the initial "S" is a contraction of SNAP and the "R" stands for Reactor. However, the designation S2DS, where the final "S" stands for System, has also been used to identify the same reactor. The total system, of course, also includes components for heat transfer, shielding, electrical power generation, instrumentation/control, and structural support. The only SNAP reactor that powered a flight system (FS) was a component of FS-4 of the SNAP 10A series. The FS-3 is the ground-tested duplicate of that reactor. Fuel elements of the ground-test reactor are called 10A FS-3 fuel, often written as 10FS-3 or S10FS-3. However, the latter substitution is not accurate, because there was a SNAP 10 (S10). Its design was radically different from the $10 \mathrm{~A}$ reactors, and it was never built. A SNAP 4 reactor was also designed but not built.

The Shield Test Reactor (STR) is also designated the STF reactor, where "F" refers to the facility - the entire installation in which components were exposed to the irradiation field. This dual-designated reactor is different from the Shield Test and Irradiation Reactor (STIR), which operated at much higher power ( $1 \mathrm{MW}$ versus $50 \mathrm{~kW}$ ) and used MTR rather than SNAP-type fuel elements.

Although the SNAP reactor program nomenclature is not consistent, the in-pile fuel experiments are all designated by NAA-; followed by numerals. These are roughiy in chronological order, although some of the experiments were irradiated in different reactors. 


\subsection{REFERENCES}

La51 - R. A. Laubenstein, "Preliminary Considerations on the Feasibility of an Auxiliary Power Plant to be Operated from Radioactive Fission Products," Atomics International Report NAA-SR-152 (October 1951) (22 pages) 


\section{SNAP FUELS - GENERAL BACKGROUND}

All SNAP reactors utilize the same solid, homogeneous mixture of fuel (uranium, $93 \%{ }^{235} \mathrm{U}$ ) and moderator (hydrogen, as $\mathrm{ZrH}_{\mathrm{x}}$ ), designated $\mathrm{ZrUH}_{\mathrm{x}}$ or $\mathrm{UZrH}_{\mathrm{x}}$. The total uranium content ranges from 7 to $10.5 \mathrm{wt} \%$. There are several ways of designating the hydrogen content. $\mathrm{N}_{\mathrm{H}}$ is the number of hydrogen atoms per $\mathrm{cm}^{3}$ of the mixture, usually near 6 (understood to be multiplied by $10^{22}$ ). Alternatively, the $(\mathrm{H} / \mathrm{Zr})$ ratio, $\mathrm{H}$ atoms to $\mathrm{Zr}$ atoms, is used. This is typically 1.6 to 1.7 , with a. corresponding hydride formula of $\mathrm{ZrH}_{1.6}$ or $\mathrm{ZrH}_{1.7}$, and represents about $1.6 \mathrm{wt} \%$ hydrogen.

SNAP.fuel elements consisted of an unsegmented, cylindrical fuel rod enclosed in a metal tube sealed by 'metal end caps. The STR elements operated in a water pool at $65^{\circ} \mathrm{F}$, and were adequately clad in bare (uncoated) Type 6061 aluminum alloy. All of the other SNAP reactors operated with a liquid metal (eutectic $\mathrm{NaK}, 78 \mathrm{wt} \%$ potassium) coolant, flowing upward along the fuel element lengths, at temperatures of $1200^{\circ} \mathrm{F}$ and above. Cladding for these reactors was Type 347 stainless steel or the nickel-based alloy Hastelloy $\mathrm{N}$, where the latter was the most commonly used.

The chemical form of hydrogen in SNAP fuel is designated $\mathrm{ZrH}_{\mathrm{x}}$. For temperatures in the range of 1400 to $1500^{\circ} \mathrm{F}$, this material retains an $\mathrm{N}_{\mathrm{H}}$ near that of cold water. Nevertheless, to minimize loss of hydrogen by permeation through the cladding over long operation at elevated temperatures, the entire inside cladding surface, including end caps, was coated with a glass-ceramic-mixture. This composition was gradually refined so that a very low hydrogen loss rate was achieved, even under extreme conditions, provided only that the metal cladding remained intact.

It is ETEC's understanding that all of the SNAP fuels in storage at INEL have been declad. The following discussion thus deals primarily with the fuel rods themselyes. Further, in this report we distinguish carefully between fuel rods and fuel elements. The fuel rods are the bare fuel material $\left(\mathrm{ZrUH}_{\mathrm{x}}\right)$, and the fuel elements are the clad assemblies. Some of the post-irradiation examination work was performed on the clad assemblies, and (usually) more detailed examinations .were subsequently performed on selected declad fuel materials.

SNAP reactor cores were "single use." No refueling was ever planned or performed. The entire reactor assembly, including the fuel; constituted an experiment, en route to a possible flight system. Thus the entire reactor system was disassembled following irradiation for detailed examination.

Both the fuel elements and the matching fuel rods were identified by serial numbers. The locations of those numbers on the rods and assemblies are shown on available engineering drawings; where one must take care to identify the latest design revisions.

\subsection{THE FUEL ROD}

\subsubsection{Zirconium-Uranium Alloy}

The initial zirconium-uranium alloy was produced by multiple consumable arc meltings and extrusions from reactor-grade enriched uranium metal and crystal bar-zirconium. This process, as all aspects of SNAP fuel production, was rigidly controlled by written procedures and specifications, and the SNAP 10 and SNAP. 8 fabrication were monitored by an independent $\mathrm{QA}$ organization. The $\mathrm{Zr}-\mathrm{U}$ alloy composition formed is located in that part of the $\mathrm{Zr}-\mathrm{U}$ equilibrium diagram that shows (at low temperatures) $\delta$-phase $\mathrm{UZr}_{2}$ in a matrix of $\mathrm{Zr}(\mathrm{Mo90})$. 


\subsubsection{Massive Hydriding}

The zirconium-uranium alloy rod is converted to a hydride by diffusion of hydrogen gas at high temperatures $\left(1600^{\circ} \mathrm{F}\right.$ peak). In this procedure the fuel volume increases by more than $15 \%$, but dense, crack-free $\mathrm{ZrUH}_{x}$ can be produced by close control of process variables, including temperature vs. time and hydrogen pressure. The resulting fuel rod retains its integrity (hence, "massive hydriding") (Reference Gi56). Because the massive hydriding is conducted isothermally, the as-built $(\mathrm{H} / \mathrm{Zr})$ ratio is essentially constant along the element length.

It was found during this work that the yield of acceptable fuel rods was greatly increased, with simultaneous improvement in microstructure, by adding $0.15 \pm 0.05$ weight-\% of $\mathrm{ZrC}$ (called the "modifier") to the melt (Ra63). In AI literature, the quantity $(\mathrm{H} / \mathrm{Zr})_{\text {eff }}$ is the ratio of $\mathrm{H}$-to- $\mathrm{Zr}$ atoms calculated on the assumption that $\mathrm{ZrC}$ does not hydride (Ar74). However, a later study showed that the $\mathrm{ZrC}$ tends to form the compound $\mathrm{ZrC} \cdot \mathrm{ZrH}_{\mathrm{y}}$, where y can approach 2 (Ta65). No correction was ever made for this contingency in calculating $(\mathrm{H} / \mathrm{Zr})_{\text {eff }}$ The hydrogen dissociation pressures in fuel made with the $\mathrm{ZrC}$ addition were found to be lower than those in the initial composition (Jo64).

\subsubsection{Fuel Microstructure (Ra63)}

All SNAP fuels consist of a dispersion of uranium-rich particles and modifier particles in a matrix of substoichiometric $\mathrm{ZrH}_{2}$, which is the terminal composition in the $\mathrm{Zr}-\mathrm{H}$ equilibrium diagram (Mo68a). On an atomic basis, hydrogen constitutes $66-2 / 3 \%$ of this compound. In the massive hydriding of ZrU alloy, the uranium is forced out of combination with $\mathrm{Zr}$, while the hydrogen atoms constitute between $30 \%$ and $50 \%$ of the $\mathrm{Zr}$-H mixture. The uranium does not hydride, but remains in micron-size particles in the $\mathrm{ZrH}_{\mathrm{x}}$ matrix (Ra65, Pe66, Mo68a, Mo68b).

As the $\mathrm{H} / \mathrm{Zr}$ ratio increases during the hydriding process, the resulting $\mathrm{ZrH}_{\mathrm{x}}$ undergoes a series of phase changes, culminating in the face-centered tetragonal $\varepsilon$-phase with its characteristic banded microstructure. These phase changes are accompanied by volume changes, which must be taken into account in conducting the massive hydriding process. Also, they enter into the changes produced by reactor operation.

\section{2:2. BARRIERS TO HYDROGEN PERMEATION (Ro61, Bu64)}

Retention of hydrogen in the fuel rods was greatly improved by lining the inside of the cladding, including end caps, with a silicate composition. Like other constituents of the SNAP fuel, the composition was changed incrementally, based on testing, to minimize chemical interactions with the hydrogen and to reduce neutron absorption.

The barrier material was applied in separate layers. A bumable "poison," $\mathrm{Sm}_{2} \mathrm{O}_{3}$, was incorporated in the final layer. Ideally, the fuel rod would "see" only the $\mathrm{Sm}_{2} \mathrm{O}_{3}$-bearing layer and the gas atmosphere used during the element assembly procedure.

\subsection{FUEL ELEMENT ASSEMBLY AND TESTING}

The fuel element tubular cladding and one end closure were welded before the internal hydrogen barrier layers were applied. The fuel rod was then inserted, and the coating on the cladding was fused to the precoated closure at the other end prior to welding on the end cap to seal the element. One sealing procedure 
minimized disruption of the coating by using a two-piece end closure arrangement. A coated "cup plug" was inserted first, and "blended" at high temperature to the coating on the inside of the cladding. A separate uncoated end cap was then welded to the cladding, along an uncoated area. Appropriate temperature controls were used to minimize deleterious effects to the "blended" coating. This end of the fuel element was inserted into the lower grid of the reactor core tank, near the coolant entrance, where its temperature was lowest.

Every element was tested after fabrication to determine whether the hydrogen permeation rate met the specified permissible maximum. There were many additional acceptance tests, including exposure to the shock and vibration loads expected from the launch and orbital operation of the flight systems. The elements in general proved to be remarkably unaffected by any of these mechanical loads. Thermophysical properties of the unirradiated elements were measured to provide baseline values (Na67) for comparison, with post-irradiation measurements.

\subsection{SNAP FUEL QUALITY SYSTEMS}

SNAP fuel was produced during the late 1950's through 1967. During this period, the sophisticated modem total quality assurance program documents, such as NQA-1, RDT F2-2, and the ISO 9000 series, were not in existence. Total quality assurance programs cover quality provisions for management, development, design, procurement, manufacture, test and inspection, construction, maintenance and modification, and operation. The most comprehensive quality system requirement available at the time of SNAP fuel production was defined in military specification MIL-Q-9858A. This document provided . requirements for, and was concerned exclusively with, procurement, manufacture, and inspection of deliverable production hardware. Its approach can best be termed quality control. This specification was never a requirement of the SNAP reactor development contract between the AEC and Atomics Intemational. However, AI did at this time have in place a quality system that met MIL-Q-9858A. Starting in 1962, this military-developed system was followed for the fabrication of SNAP 10A and SNAP 8 fuels by organizationally divorced fabrication and quality control personnel. Fuel for the SER, S2DR, and STF reactors, as well as irradiation experiments, were fabricated, tested, and inspected by Engineering Department development laboratory personnel, under a set of Engineering Management Procedures . established by the Engineering Department vice president. All reactor operations and post-irradiation examination of SNAP fuels were controlled by these Engineering Management Procedures. Manufacturing, inspection, and test planning for SNAP 10A and SNAP 8 fuel from procurement through delivery for reactor:use are given in various reports, as referenced in individual reactor sections of this report, along with.detailed post-irradiation test and inspection results. Similar data in less detail are available for some reactor fuels manufactured prior to SNAP10A/8 production.

\subsection{RADIATION EFFECTS}

Although post-irradiation examination of the fuel elements from the lower-power reactors (particularly 10A FS-3) showed that they remained intact, the S8ER and S8DR fuel elements showed extensive failures (Pe66, Mi67a). These failures included cladding cracks, fuel rod deformation, and fuel rod cracks. Lessons leamed (and applied) from S8ER were not adequate to eliminate failures in S8DR. Termination of the development program in 1976 prevented the testing of additional improvements.

The most extensive post-irradiation studies on core elements were for S8ER and S8DR, to identify the underlying causes of fuel element failure. A summary of irradiation phenomena in S8ER fuel (Pe66; Section VII; too lengthy to include here) describes the microstructure of the as-fabricated fuel, plus the 
processes at the atomistic level during reactor operation which could affect the overall element performance. Although specific to high-power S8ER operation, the analysis is generally applicable to all SNAP reactor fuels.

\subsubsection{Reactor Operation}

Because of the axial and radial temperature gradients in the operating reactors (particulariy axially along - the coolant flow direction), the initial uniform $(\mathrm{H} / \mathrm{Zr})$ profiles in the fuel elements must change. Each element, depending on its location in the core, is a closed, individual system. It is not, however, in equilibrium, because of the temperature gradient of the reactor and the fact that there can be only one steady-state hydrogen pressure inside the element. The $(\mathrm{H} / \mathrm{Zr})$ ratio along the fuel length, starting at the coolant entrance (lower grid), adjusts to provide a single, steady-state hydrogen partial pressure corresponding to the $(\mathrm{H} / \mathrm{Zr})$ ratio and to the temperature at the given location. These variations in $(\mathrm{H} / \mathrm{Zr})$ are reflected in changes in fuel rod density and volume. As an example, the temperature profile for the SER is indicated in Ref. Fe59. In the later SNAP reactors, both axial and diametrical clearance was provided to allow for fuel rod volume changes under irradiation.

The effect of reactor operation is illustrated by the changes in $(\mathrm{H} / \mathrm{Zr})$ in the $10 \mathrm{~A}$ FS-3 fuel elements, after over 10,000 hours of operation with reactor outlet temperatures up to $1055^{\circ} \mathrm{F}$; as shown in the following table. As expected, the bottoms of the fuel rods, at the cooler location, had a higher $(\mathrm{H} / \mathrm{Zr})_{\text {eff }}$ than the as-fabricated values. The tops had lower values. Overall, the 37 fuel rods in 10A FS-3 showed very good hydrogen retention.

SNAP 10A FS-3 Hydrogen Analysis Summary

\begin{tabular}{|c|c|c|}
\hline Fuel Rod & $\begin{array}{c}\text { As-Fabricated } \\
(\mathrm{H} / \mathrm{Zr})_{\text {eff }}\end{array}$ & $\begin{array}{c}\text { Post-Irradiation (H/Zr) } \\
\text { (Range from Core Top to Bottom) }\end{array}$ \\
\hline 422 & 1.840 & 1.754 to 1.862 \\
331 & 1.830 & 1.760 to 1.860 \\
529 & 1.770 & 1.680 to 1.800 \\
\hline
\end{tabular}

The 10A FS-3 reactor operated at a fairly steady power level ( 37 to $38 \mathrm{~kW}$ ). Other reactors experienced large, abrupt power level changes, deliberately induced to determine the reactor physics (i.e., the control characteristics). Such changes imposed rapid temperature transients which were often repeated, to the potential detriment of fuel element integrity.

The SNAP 2/10A reactors operated at a mean neutron fission energy near $0.18 \mathrm{eV}$ (Go67c, Table 3.1), while S8DR operated at about $0.26 \mathrm{eV}$ (Sw69). These are slightly epithermal. As a result, the radial neutron distribution does not resemble that of some water or graphite moderated cores, where the thermal flux peaks in the moderator and is depressed in the fuel. The flux is fairly flat across a fuel element, resulting in a rather flat radial burnup profile across each element. Radially across the whole core, the flux and burnup are highest at the center element, and lowest at the outside elements near the edge of the cylindrical core. The flux profile in the axial direction is not symmetrical. It is higher below midplane, because of the higher $(\mathrm{H} / \mathrm{Zr})$ near the bottom ends of the fuel. 


\subsubsection{Structural Effects of Fission}

Microstructural effects of the fission products and neutrons appeared to be relatively slight. Although the fuel material is brittle, it is strong. The ultimate tensile strength increases with temperature, to a value for unirradiated $\mathrm{Zr}-10 \mathrm{UH}_{1.74}$ near $10,000 \mathrm{psi}$ at about $1200^{\circ} \mathrm{F}$ (Lu64). Swelling due to accumulated fission products was observed (Mi67a), which showed the small (micron) size of the uranium particles.

The volume changes in uranium due to its phase changes over the SNAP reactor operational temperature range, starting at room temperature, did not appear significant. This may be because of the small size of the particles or the "strong box" effect provided by the $\mathrm{ZrH}_{\mathrm{x}}$, or both. Empirical relations were developed among fuel growth, temperature, and bumup, although a phenomenological basis was proposed (Li73).

Macro effects were a different story. Local overheating of fuel (by coolant flow starvation) resulted in drastic deformation, from the combined effects of dehydriding (volume/density changes) and the higher fission density in the adjacent higher $(\mathrm{H} / \mathrm{Zr})$ regions. Fuel rod bowing stressed the cladding, resulting in cladding cracking (Da70).

\subsubsection{Burnup and Transmutation (Ре66)}

Because the principal interest in the SNAP reactor program was on the overall system operation, relatively little emphasis was placed on achieving high bumup. It was rarely as high as $0.1 \cdot$ metal-atom \%. The highest burnup (at least for fuels stored at INEL) was 0.77 metal-atom \% for the NAA-117 in-pile experiment.

Profiles of gamma activity along the fuel rod length were determined by gamma scanning in the AIHL, and were then calibrated by measurements made on fuel samples cut from selected locations. The samples were analyzed in several ways, of which mass spectroscopy was deemed the most.accurate (Go67b).

Neutron capture did occur in the uranium. However, with only about 7 wt. $\%{ }^{238} \mathrm{U}$, capture without fission was relatively slight. In S8DR the core average burnup and transmutation (plus data for each ring of fuel elements) were estimated from ring power calculations made using the computer code ANISN (Ro7.0). About 4.79 grams of ${ }^{239} \mathrm{Pu}$ were estimated to have been formed, from the 521 grams of ${ }^{238} \mathrm{U}$ initially present in the whole core. In these calculated results, the burnups of ${ }^{236} \mathrm{U}$ and ${ }^{239} \mathrm{Pu}$ were assumed negligible. The calculated ${ }^{239} \mathrm{Pu}$ formation is equivalent to $22.7 \mathrm{mg}$ of ${ }^{.239} \mathrm{Pu}$ per fuel element. No measurements were made to confirm these calculations.

\subsection{CONSIDERATIONS OF ENVIRONMENTAL EFFECTS ON FUEL}

The as-built SNAP fuel was in limited mechanical contact with the silicate-coated inside surface of the cladding, through an atmosphere which was variously-helium-air, low-pressure helium, or vacuum ( $\mathrm{Li73}$ ). Experience (Go67b) showed that if the cladding remained intact, reactor operation would produce only modest fuel growth, so that the fuel would attain its design life. After shutdown, the reactor fuel would show normal decay of fuel element radioactivity. Figure 1 shows the estimated decay of the SNAP 10A FS-4 fuel elements. with time (Sa66). FS-4, also designated SNAPSHOT-1, operated at $40.7 \mathrm{~kW}$ thermal power for 1032 hours before shutdown. The general character of the curve is valid for all SNAP fuel.

Cracked cladding allows the NaK coolant to come into direct contact with the interior of the fuel element. There is little (if any) direct effect of NaK on the fuel material. Loss of the coating at a cracked area would result in a locally higher loss rate of hydrogen. Chemical reactions did occur between the NaK and 


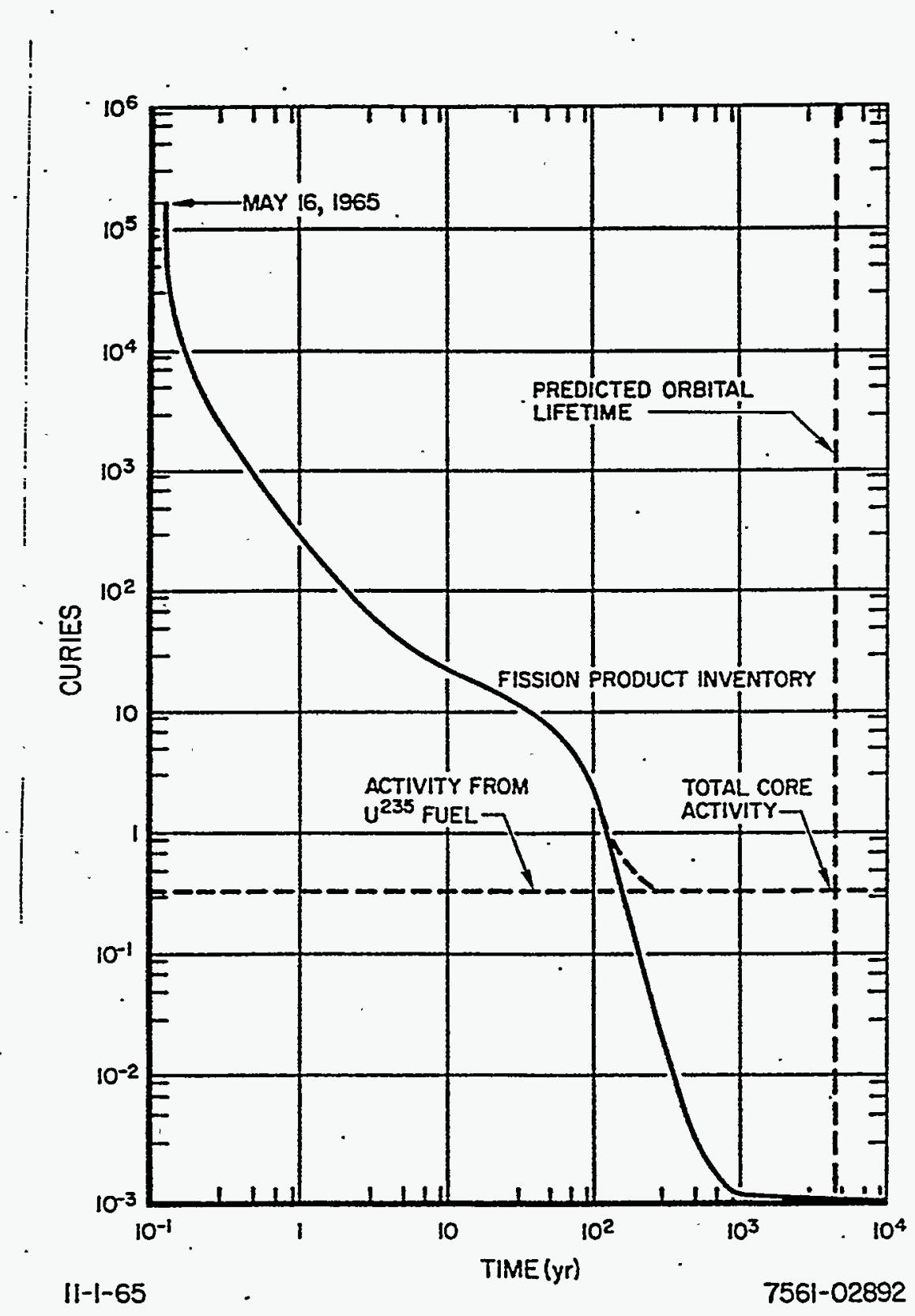

Figure 1. Calculated Fission Product Inventory Decay for SNAPSHOT-I (from Sa66).

the silicate coating. Although this has not been explored systematically, it is evident from post-irradiation examinations that whole pieces of coating were removed from the cladding, and some pieces were stuck to the fuel (Mi66a). Whether the reaction products themselves attacked the $\mathrm{ZrUH}_{x}$ fuel was not investigated.

The ground test reactors (excluding STR) were moved from the test buildings after they completed their tests to the AIHL. for-disassembly and examination. The initial AIHL atmosphere was nitrogen gas, containing less than $3 \%$ oxygen, to minimize chemical reactions with residual NaK. Fuel elements were cleaned in a butyl ether-alcohol liquid compound (Dowanol EB, Dow Chemical Company) to remove residual NaK. With cracked cladding, and sometimes cracked fuel, it could not be certain that all crevices were cleaned out. Nevertheless, fuel elements were handled, stored, and shipped in air following Dowanol 
cleaning. Communications between Aerojet Nuclear (Idaho) and Atomics International indicate that some elements retained chemically active NaK (Ad74).

Based on information received from INEL, it is our understanding that the declad fuel was (at least initially) stored in water containing $3.8 \mathrm{~g} /$ liter natural boron for criticality control (Am68). No studies

were ever made at $\mathrm{AI}$ of the possible chemical interactions between $\mathrm{ZrUH}_{\mathbf{x}}$ and water or such a solution.

\subsection{FUEL REFERENCES}

Ad74 T. Adamson (Aerojet Nuclear), in Atomics International Telephone Conversation Record to V.J. Schaubert (AI) dated 28 January 1974

Am68 C. B. Amberson (Idaho Nuclear Corporation), "SNAP Fuels from A.I. in 1967-1968 Fai-9-68," Interoffice Correspondence

-Ar74 J. R. Armstrong, "Uranium-Zirconium Fuel Alloy, Hydriding of," Atomics International Specification NA0611-001 (January 1974) (11 pages)

Bu64 ..G. F. Burdi, Ed.; "SNAP Technology Handbook. Volume II. Hybrid Fuels and Claddings," Atomics International Report NAA-SR-8617, Volume II (November 1964) (129 pages)

Da70a W. H. Dauterman, "Bowing of S8DR Fuel," Atomics International Technical Information Document TI-568-24-042 (March 1970) (20 pages)

Fe59 L. D. Felten, "Axial Temperature Distribution of S.E.R. Central Fuel Element," Atomics "Intemational Technical Data Record NAA-SR-MEMO-5121 (October 1959) (8 pages)

Gi56 P.T. Gilbert, Jr., "Zirconium Hydride: A Compendium on the Systems Zirconium-Hydrogen and Hafnium-Hydrogen and Related Topics," Atomics International Report NAA-SR-1508 (October 1956) (834 pages)

G067b T. A. Golding, "Post-Irradiation Examination of Selected S10FS-3 Fuel Elements," Atomics International Technical Data Record NAA-SR-MEMO-12341 (June 1967) (28 pages)

Go67c K. G. Golliher, et al., "SNAP Engineering Test Facility Safety Analysis Report: Addendum for Intrinsic Supercriticality Experiments," Atomics Intemational Technical Data Record NAA-SRMEMO-12614 (November 1967) (80 pages)

Jo64 H. E. Johnson, "Hydrogen Dissociation Pressures of Modified SNAP Fuels," Atomics Iniemational Report NAA-SR-9295 (March 1964) (47 pages)

Li73 A. F. Lillie, D. T. McClelland, W. J. Roberts, and J. H. Walter, "Zirconium Hydride Fuel Element Performance Characteristics," Atomics International Report AI-AEC-13084 (June 1973) (75 pages)

Lu64 L. B. Lundberg, "Parametric Studies on the Short-Term Tensile Mechanical Properties of Zr-10U Alloy Hydrides," Atomics International Report NAA-SR-9875 (July 1964) (42 pages) 
Mi66a K. J. Miller, "Post-Irradiation Detailed Examination of Selected S8ER Fuel Elements," Atomics Intemational Technical Data Record NAA-SR-MEMO-12165 (1966) (complete color copy) (304 pages)

Mi67a K. J. Miller, "Electron Microscopy Analysis of Irradiated SNAP 8 Fuel," Atomics International Report NAA-SR-12449 (August 1967) (66 pages)

Mo68a K. E. Moore, W. A. Young, M. M. Nakata, and C. A. Smith, "Phase Relations at High Hydrogen Contents in the SNAP Fuel System," Atomics Intemational Report NAA-SR-12587. (February 1968) (55 pages)

Mo68b K. E. Moore and M. M. Nakata, "Phase Relationships in the $(\alpha+\delta)$ Region of the Zr-H System," Atomics International Report AI-AEC-12703 (September 1968) (47 pages)

M090 W. G. Moffett, Ed., The Handbook of Binary Phase Diagrams, Voĭ. V (Genium Publishing Co., Schenectady, NY, 1990 update)

Na67. M. M. Nakata, C. J. Ambrose, and R. A. Finch, "Thermophysical Properties of SNAP Fuel Materials," Atomics International Report NAA-SR-11959 (September 1967) '(93 pages)

Pe66 H. Pearlman, et al,. "SNAP 8 Experimental Reactor Fuel Element Behavior: Atomics Internátional Task Force Review," Atomics Intemational Report NAA-SR-MEMO-12210 (November 1966) (73 pages)

Ra63 J. W. Raymond, "Development of a High Yield $90 \mathrm{Zr}$ - 10 U Alloy Massive Hydride," Atomics International Report NAA-SR-7305 (January 1963) (22 pages)

Ra65 J. W. Raymond, "Phase Relationships and Microstructures in the Zirconium - 10 wt \% Uranium Alloy Hydride System," Atomics Intemational Report NAA-SR-10965 (November 1965) (36 pages)

Ro61* C. J. Romero and S. Elchyshyn, "Cladding Development for SER Fuel Elements," Atomics Intemational Report NAA-SR-4831 (February 1961) (42 pages)

Ro70 H. Rood, "S8DR Fuel Burmup and Transmutation Data," Atomics Intemational Technical Information Document TI-568-24-063 (July 1970) (5 pages)

Sa66 W. B. Sayer and R. S. Hart, "The Predicted Fission Product Decay of Snapshot-1," Atomics Intemational Report NAA-SR-11642 (January 1966) (20 pages)

Sw69* L. D. Swenson, "SNAP 8 Development Reactor Nuclear Analysis," Atomics International Report AI-AEC-12864 (October 1969) (83 pages)

Ta65 H. Taketani, L. Silverman, and W. L. Korst, "Identification of the Modifier in SNAP Fuel," Atomics International Report NAA-SR-10174 (February 1965) (21 pages)

(Reports identified with an asterisk were referenced in the WINCO SNAP summary report WINCO-1222 by $R$. E. Lords.) 


\section{ISSUES FOR THE SAFE DISPOSAL OF STORED SNAP FUELS}

SNAP fuels were never intended as waste forms for repository emplacement. The safety issues involved in space flight were studied extensively (De65, Cu65, Go67c). The emphasis was on intrinsic reactor safety, and on safe return of the reactor from orbit. Other than investigations of nuclear criticality when immersed in water (should the reactor land in the sea), only one study is known to have been made on the chemical reaction of water with SNAP fuel.

\subsection{SNAP FUELS IN THE STORAGE ENVIRONMENT}

. As indicated in Ref. Am68 and more recently in discussions with INEL personnel, the irradiated declad fuel rods were. stored at INEL in aluminum cans that have been breached by water. Although the radioactivity of the fuel has decayed substantially, there may still be a possibility of radiolysis of the water, which would produce hydrogen gas and solute species.

The choice of aluminum for the canister raises the possibility of galvanic action. A survey of potential . electrode reactions involving aluminum and uranium when linked by an electrolyte shows that aluminum would be anodic to the uranium. It would thus corrode sacrificially, protecting the uranium (We85). Dissolution of aluminum would change the $\mathrm{pH}$ of the water, with effects on the uranium that have not been investigated.

In the event that the canisters go dry, fuel reactions with air are possible, especially if the fuel material is fragmented. The large surface-to-volume ratio favors a reaction, which can progress rapidly enough to cause a fire. The personal experience of one of us (hp) with a barrel of unalloyed zirconium turnings, initially covered with water, illustrated this vividly: corrosion of a barrel (not observed until after the fact) exposed high surface-to-volume-ratio zirconium turnings to air and produced a fire. Under some circumstances zirconium hydride powder can explode in air (Gi56).

These potential reactions also probably hold true for $\mathrm{ZrUH}_{\mathrm{x}}$, because the particulate uranium is not stable either in air or in water. All of the potential reactions with air and water could be slowed substantially by the presence of an oxide layer on the surface of the fuel piece (or particle). However, stability of such a layer over an indefinitely long period of time cannot be assured.

\subsection{RELEVANT AI EXPERIENCE}

Chemical effects of water or air on irradiated $\mathrm{ZrUH}_{\mathrm{x}}$ fuel were not systematically investigated in the AI program. As part of the fuel development program for the SNAP 4 system, a very limited investigaticn was made of corrosion effects on bare fuel, in contact with Type 304 and Type 446 steels. The SNAP 4 system was based on a boiling water reactor that used SNAP-type fuel clad in austenitic stainless steel, such as Type 304. In another program, the oxidation behavior of the bare fuel alloy was studied.

\subsubsection{Compatibility Tests for SNAP 4 (St63)}

Samples of unirradiated $\mathrm{Zr}-15 \mathrm{U}-\mathrm{H}_{\mathrm{x}}$, "sandwiched" between flat plates of Type 304 and Type 446 steels, were exposed in water in both pyrex and Type 304 containers. They were held in an autoclave at $570^{\circ} \mathrm{F}$ and 1250 psi for 400 hours. Cracking of the fuel was observed in the pyrex container samples. This was attributed to attack by water on the pyrex. glass, resulting.in increased pH from 7 to about 10. Fuel 
samples in the Type 304 container were unaffected. However, the Type 446 plates that formed part of the "sandwich" sample were attacked by the water. The pH of the water in that container decreased from 7 to about 5.2. There is no statement in Ref. St63 about the hydrogen content of the fuel sample, before .or after exposure. However, Ref. Bu64 (Table 1.1.6) identifies the fuel composition as $\mathrm{Zr}-15 \mathrm{U}-\mathrm{H}_{1.6}$.

It is difficult to extrapolate these results to irradiated SNAP fuel stored in water under less -aggressive conditions. There is some implication that water at a pH of 7 or below will not attack $\mathrm{ZrUH}_{x}$, but the influence of other metals linked to the fuel material via an electrolytic solution is not clear.

\subsubsection{Oxidation Kinetics in the Zr-U System}

A study was made. of the reaction of the unirradiated, unhydrided fuel alloy with air and with oxygen gas (Ha65) in order to provide basic data on the fate of SNAP fuel re-entering the atmosphere from earth orbit. Samples of $\mathrm{Zr}-10 \mathrm{U}$ (with and without modifier) and of pure zirconium metal were exposed over a temperature range from $570^{\circ} \mathrm{C}$ to $1190^{\circ} \mathrm{C}$. Parabolic and cubic rate laws were found to fit the data for weight gain versus time, up to "breakaway." The samples were dense, 1-inch-diameter spheres.

At the high test temperatures, hydrided fuel would certainly-lose hydrogen, leading to changes in density and sample cracking. The increased surface area (over the intact sphere) would accelerate oxidation. The effect of irradiation on the test results was not investigated.

\subsubsection{Dehydriding}

Samples of irradiated SNAP fuels.were dehydrided in the process of studying fission gas retention (Ce64). and in experiments aimed solely at the dehydriding process (Le66). High temperatures $\left(2000^{\circ} \mathrm{F}\right.$ to 3200 $\left.{ }^{\circ} \mathrm{F}\right)$ and times from 3 to 8 hours were used to evaluate the release dependence on these variables (Ce64).

\subsubsection{Conclusions}

Data available from the limited AI experiments on the reactions between unirradiated fuel alloy or hydrided $\mathrm{Zr}-\mathrm{U}$ are inadequate to predict irradiated fuel behavior for long-term storage in water or air. Further, it is not evident that dehydriding would be a worthwhile process to improve the storage characteristics of irradiated SNAP fuel. Alternative methods for treating the fuel are suggested in Section 5.

\subsection{REFERENCES}

Bu64 G. F. Burdi, Ed., "SNAP Technology. Handbook. Volume II. Hybrid Fuels and Claddings," Atomics International Report NAA-SR-8617, Volume II (November 1964) (129 pages)

- Ce64 W. M. Cegelski, "Fission Product Release from Irradiated Uranium-Zirconium Hydride SNAP Fuel," Atomics International Report NAA-SR-9673 (July 1964) (37 pages)

Cu65 G. E. Culley, "Analysis of SNAPTRAN-3 Destructive Experiment Debris," Atomics International Report NAA-SR-11584 (December 1965) (37 pages)

De65 R. L. Detterman, "Progress Report: SNAP Aerospace Safety Program April-June 1965," Atomics International Report NAA-SR-11497 (August 1965) (one of a series, 39 pages) 
Gi56 P. T. Gilbert, Jr., "Zirconium Hydride: A Compendium on the Systems Zirconium-Hydrogen and Hafnium-Hydrogen and Related Topics," Atomics International Report NAA-SR-1508 (October 1956) (834 pages)

Go67c K. G. Golliher, et al., "SNAP Engineering Test Facility Safety Analysis Report: Addendum for Intrinsic Supercriticality Experiments," Atomics International Technical Data Record NAA-SRMEMO-12614'(1967) (80 pages)

Ha65 S. D. Harkness, "The Oxidation Kinetics of SNAP Fuel Alloy: Modified 90-10 ZirconiumUranium," Atomics Intemational Technical Data Record NAA-SR-MEMO-10914 (January 1965) (33 pages)

Le66 S. K. Lee, "A Study of Dehydriding of S8ER Fuel," Atomics International Technical Data Record NAA-SR-MEMO-12197 (October 1966) (20 pages)

St63 . D. H. Stone; "Corrosion Tests of Candidate SNAP 4 Fuel Element Materials," Atomics International Technical-Data Record NAA-SR-TDR-8068 (February 1963) (6 pages)

We85 R. C. Weast, Ed., CRC Handbook of Chemistry and Physics, 66th Edition (CRC Press Inc., Boca Raton, FL, 1985) 


\section{DATA-GATHERING APPROACH AND REPORT CONTENTS}

The approach used in this task was to identify and examine sources of SNAP information at ETEC and Rocketdyne, and to assemble and review the fuel-related information for its relevance to INEL needs. Those sources investigated included the Rocketdyne Technical Information Center (TIC, which incorporates the former Atomics International library resources), the ETEC. library, Rocketdyne's Advanced Power Systems (formerly Atomics International) Technical Data Center, archived Atomics Intemational shipping records, archived Atomics Intemational Hot Laboratory data records, and other available archived personal and storage files.

The Rocketdyne TIC and ETEC library were the source of a large number of formal reports and technical data records, while the Technical Data Center was the source of technical information documents, engineering drawings, and specifications (typically on microfiche or microfilm). The archived shipping files provided detailed shipping information over the time period of SNAP fuel transfers to INEL and other disposal locations. The AIHL and miscellaneous personal files provided a large volume of source data (data sheets, strip chart recordings, internal letters, photographs, negatives, examination.plans and proposals, etc.), particularly for 10FS-3, S8ER, and S8DR. We uncovered several file cabinet drawers full of unsorted photomicrograph negatives for the pre- and post-irradiation examination of fuel elements and fuel rods.

This report covers the SNAP documentation we have assembled, reviewed, and deem to have relevance to the characterization of the SNAP fuel rods now.in storage at INEL. It is divided into separate sections according to reactor core and in-pile experiment, where each section provides the following information:

(1) A general description .of each system.

(2) A listing of the documentation found for each item of interest, as outlined in the INEL Memo Purchase Order. This is presented as a reference number for each document, followed by a brief description of the document contents. Areas of INEL interest where no information was found were left blank, and serve to identify those areas.

(3) A complete reference. list for the documentation assembled for that SNAP core or experiment. The reference code used in this report identifies each document by using the first two characters of the first author's last name plus the last two digits of the year of publication. Where there are duplications, the characters a,b,c etc. are added to distinguish documents. Those documents referenced in the WINCO report "SNAP and AI Fuel Summary Report" by R. E. Lords (WINCO1222, August 1994) are identified in the bibliographies by an "*" following the reference code.

(4) A spreadsheet summarizing the shipping records for that fuel element type, correlater both with available INEL receiving records and with our source documentation on fuel fabrication.

In addition, Appendix 1 provides a combined listing of all the reference documents covered in this report. The formal documentation summarized in Appendix 1 totals well over 10,000 pages. It does not include several file cabinets full of post-irradiation examination source data and negatives which could not be readily indexed.

A large volume of additional SNAP-related information was also uncovered during this investigation that is not referenced in this report. That information includes a large number of development reports. covering preliminary work that did not necessarily represent the final reactor systems, several qualification testing 
reports (including thermal cycling, simulation-launch vibration tests, etc.), as those tests were performed using natural uranium, reports on other (non-fuel) components of the reactor systems, and documentation on the SNAPTRAN cores and SNAP Critical Assembly (SCA), which are outside the scope of this investigation. 


\section{RECOMMENDATIONS FOR FUTURE WORK}

The document search and review activities performed as part of the present work led to the acquisition of more source documentation than could be reviewed and evaluated as part of this program. Additionally, we have developed views on the ultimate disposition of the SNAP fuel materials now stored at INEL. Those fuel materials contain about $26.3 \mathrm{~kg}$ of uranium, of which about $24.4 \mathrm{~kg}$ is ${ }^{235} \mathrm{U}$. We offer the following recommendations for consideration in future work leading to the final disposition of the fuels.

\subsection{COMPLETION OF DOCUMENT REVIEW AND EVALUATION}

The source documents relating to the SNAP fuels (AIHL photographs, $\log$ books, and other analyses of various kinds) are all, as of the date of this report, well over 20 years old. This material was found scattered in several storage locations, and provided more information than time and funding limitations permitted us to review and evaluate. In the interest of providing a more complete account of the fuel used in this now inactive program, we recommend an extension to the Memorandum Purchase Order effort of 4 - 6 man-months at ETEC/Rocketdyne to complete this evaluation.

\subsection{COMPUTER CODE CALCULATIONS}

Some of the key post-irradiation fuel information, such as transuranic and fission product inventories, were not measured at the time the fuels were examined, and computer codes for predicting this information were relatively primitive. (See, for example, Sa66.) Present-day, more sophisticated computer codes such as ORIGEN2 can be applied to the available data to provide this information. We recommend such calculations, and estimate that such an effort at ETEC would require about. 3 man-months.

\subsection{ASSESSMENT OF PRESENT CONDITION OF STORED FUEL}

Because of the potential chemical interaction of the fuels with water, and mechanical shocks of handling, we strongly recommend examination of representative samples of the fuel. This should include the determination of microstructure, physical state (e.g., intact or crumbled), and overall chemical condition (adherent or flaky oxide, etc.). We recommend beginning with samples of fuel material with the highest bumup (0.77 metal-atom \%, from Experiment NAA-117-1) and with wafers cut from S8DR fuel.

The main effort for such an examination must take place at INEL. However, ETEC/Rocketdyne can provide guidance for hot cell examination, based on our extensive documentation of past SNAP fuel analyses (e.g., Sh64, Ra65, Mc65, Ra65a, and the many detailed AI post-irradiation examinations, such as Mi66a and Mi67), and has personnel available who are familiar with in-cell metallography. We estimate a 12-man-month effort at INEL and a 2-man-month support effort at ETEC/Rocketdyne to perform this examination.

\subsection{PROCESSES TO CONVERT SNAP FUELS TO ACCEPTABLE WASTE FORMS}

In view of the present DOE-ordered shutdown of spent nuclear fuel reprocessing (Be94), there are only three alternatives for handling SNAP fuels. The first is simply to leave them where they are in INEL 
storage pools, the second is to place them in a repository in their present form, and the third is to perform some type of chemical conditioning before repository emplacement. The first alternative is obviously unacceptable because it does not provide a long-term storage solution.

Past AI determinations of the microstructure of irradiated SNAP fuels provide information that bears directly on the second alternative. These investigations have established that the uranium in the $\mathrm{ZrH}_{x}$ matrix is present in small (micron-size) particulate metallic form (Рe66, Mi67). The chemical reactivity of both uranium and zirconium hydride is potentially high, both in air and in water. The current status of the stored SNAP fuels suggests that surface layers, probably oxide, may be present that limit or suppress chemical reactions. Dependence on the integrity of these layers for the indefinite future poses a risk, and thus raises questions on repository disposal of the SNAP fuels in their present form.

The third alternative, chemical conditioning of the fuels before repository disposal, is the most viable option. Glass is the composition of choice for immobilizing high level waste (HLW) in France, and glass technology is further advanced than altematives at present in the U.S. However, the feed for glassforming in France (and in the U.S.) is the waste stream from chemical reprocessing of spent nuclear fuel (SNF) - not the SNF itself. More compact waste forms like Synroc or Tailored Ceramics have the potential to support a higher loading of HLW than glass. This would be required for the emplacement of SNF materials like SNAP and TRIGA fuel in a future repository.

These compact waste forms have been investigated in the past to "lock" radioactive elements into stable chemical structures for final disposal. Tailored Ceramics were studied intensely for several years at Rockwell International (Gr83, Mc83). This waste form was intended primarily for a Purex waste stream, but may be applicable to small-batch, special fuel compositions like SNAP. We recommend a study ofthe-applicability of this type of chemical conditioning for the SNAP fuels, and have personnel available at ETEC/Rocketdyne who participated in the Tailored Ceramics program. We suggest a 9-man-month . study at ETEC of applicable chemical conditioning processes to produce stable waste forms from SNAP fuels, with 2-man-months of support from INEL personnel.

A recent INEL listing of stored spent fuels (Fi94) includes both SNAP and TRIGA fuel types. Generically, TRIGA fuel is also hydrided $\mathrm{Zr}-\mathrm{U}$ alloy, usually with a lower hydrogen content than SNAP fuel. (See, for example, Si61.) It is possible that TRIGA fuel would be amenable to chemical treatment analogous to SNAP fuel, providing an additional benefit from this proposed study.

\subsection{REFERENCES}

Be94 C. L. Bendixsen, in Proc. 1994 International High Level Radioactive Waste Management Conference, American Nuclear Society, 22-26 May 1994

Fi94 D. L. Fillmore, "Categorization of Department of Energy Spent Nuclear Fuiel," in Proc. 1994 International High Level Radioactive Waste Management Conference, American Nuclear Society, 22-26 May 1994

Gr83 L. F. Grantham, et al., "Process Description and Plant Design for Preparing Ceramic High Level Waste Forms," Rockwell Intemational Energy Systems Group Report ESG-DOE-13397 (February 1983) (71 pages)

Mc65 D. D. McAfee, "Hot Laboratory Metallography of SNAP 8 Fuel," Atomics Intemational Technical Data Record NAA-SR-MEMO-11217 (March 1965) (12 pages) 
Mc83 R. L. McKisson, et al., "Commercial High Level Waste Management, Options and Economics: A Comparative Analysis of the Ceramic and Glass Waste Forms, " Rockwell International Energy Systems Group Report ESG-DOE-13391 (February 1983) (145 pages)

Mi66a K. J. Miller, "Post-Irradiation Detailed Examination of Selected S8ER Fuel Elements," Atomics Intemational Technical Data Record NAA-SR-MEMO-12165 (1966) (complete color copy) (304 pages)

Mi67 K. J. Miller, "Electron Microscopy Analysis of Irradiated S8ER and NAA 115-1 Fuel," Atomics Intemational Technical Data Record NAA-SR-MEMO-12368 (March 1967) (51 pages)

Pe66 H. Peariman, et al, "SNAP 8 Experimental Reactor Fuel Element Behavior: Atomics International Task Force Review," Atomics Intemational Report NAA-SR-MEMO-12210 (November 1966) (73 pages)

Ra65 J. W. Raymond, "Phase Relationships and Microstructures in the Zirconium - 10 wt \% Uranium Alloy Hydride System," Atomics Intemational Report NAA-SR-10965 (November 1965) (36 pages)

Ra65a J. W. Raymond and D. T. Shoop, "The Metallography of Zirconium-Base Alloy Hydrides," Atomics Intemational Technical Data Record NAA-SR-TDR-10927 (February 1965) (9 pages)

Sa66 W. B. Sayer and R. S. Hart, "The Predicted Fission Product Decay of Snapshot-1," Atomics Intemational Report NAA-SR-11642 (January 1966) (20 pages)

Sh64 D. T. Shoop, "Metallographic Preparation of Zirconium Hydride," Atomics Intemational Technical Data Record NAA-SR-MEMO-10145 (June 1964) (7 pages)

Si61 M.T. Simnad and W. P. Wallace, "The Metallurgy of the TRIGA Fuel Elements," Elecktrotechnik und Maschinenbau 78, 581 (1961) 


\section{SNAP REACTOR FUELS}




\title{
6. SNAP-2 EXPERIMENTAL REACTOR (SER)
}

Date went critical:

- First power operation:

Thermal power:

Thermal energy:

Time at power and temperature:

Operating location:
September.19, 1959 (Hu61, Ja73)

November 5, 1959 (Ja73)

$50 \mathrm{kWt}$

$225,000 \mathrm{kWt}-\mathrm{h}$

$1900 \mathrm{~h}$ at $1200^{\circ} \mathrm{F}, 3300 \mathrm{~h}$ above $900^{\circ} \mathrm{F}$

SSFL Building 010

\subsection{SER GENERAL DESCRIPTION}

The SER was the first of the series of reactors in the SNAP program (Di67). The reactor core was made up of 61 fuel-moderator elements, 1 inch in diameter, on a triangular matrix contained in a 9-inch-diameter core vessel. Heat was removed from the core by primary NaK coolant flow, transferred to a secondary $\mathrm{NaK}$ coolant loop by means of an intermediate heat exchanger, and dissipated to the atmosphere through an airblast heat exchanger. The fuel was composed of a hydride uranium-zirconium alloy that was formed into rods and canned in thin-walled 347 stainless steel tubes. The fuel rods contained $6.88 \mathrm{wt} . \%$ uranium, $93 \%$ enriched in ${ }^{235} \mathrm{U}$, and $6 \times 10^{22}$ atoms $/ \mathrm{cm}^{3}$ of $\mathrm{H}_{2}$ in the form of $\mathrm{ZrH}_{\mathrm{x}}$. Analysis of the characteristics of the fuel alloy indicated that it could be considered as a mixture of zirconium hydride plus uranium metal with a density of $5.89 \mathrm{~g} / \mathrm{cm}^{3}$. Excess and reject fuel elements from the fabrication process were used in the Shield Test Facility (STF), covered in Section 11. General descriptions of the SER are given in references Eg59, Hu61, Be62, Di67, and Ja73.

\subsection{REACTOR AND FUEL IDENTIFICATION}

Reactor:

Also identified as:

\author{
SNAP Experimental Reactor (SER) - : \\ SNAP-2 Experimental Reactor (S2ER) \\ SNAP-II Experimental Reactor \\ SNAP-II
}

Core fuel identification: SER (same as reactor name)

Reactor designer, builder, operator: Atomics International

Reactor owner: Atomic Energy Commission (now DOE)

Fuel designer, builder: Atomics International

Fuel owner: Atomic Energy Commission (now DOE)

\subsection{SER DESIGN REACTOR PHYSICS AND CORE DESCRIPTION}

Wi58 Pre-loading nuclear analysis, to evaluate required fuel loading

Wi59 Pre-operation design summary

Hu61 Some reactor physics parameters

Be62 Operating parameters and reactor physics information

Jà73 Summary of SER parameters, including flux ratios (Table 8) 
Fuel Elements/Assemblies: 61 used in core; 68 were fabricated (Ka59)

Design Neutron Flux: Flux ratios given in Ja73 (Table 8)

Design Neutron Energy: Mean neutron fission energy near $0.18 \mathrm{eV}$ (Go67c)

Core Map and Element Locator:

Dr60, Hu61, Be62, Mi63

Core configuration (without element location identification)

\subsection{SER FUEL FABRICATION INFORMATION}

Fuel Specifications and Drawings:

Tu58 Manufacturing planning document for fabrication

Re59 Specification and engineering design drawing

B159 Quality control planning document

Ta63 Non-dimensional fuel element specifications (Table 1)

Bu64 S2ER (SER) description (Table 5.2.2), providing nominal design data, and schematic drawing

Drawing .7512-971801 "Fuel Rod Assembly - SER - Layout," showing dimensioned fuel rod as part of this assembly (05/59)

Drawing 7512-71102 "Slug-S.E.R.-End Reflector," showing Be end reflectors (06/58)

Fuel Fabrication and Quality Control:

.Dr60 Typical spectrographic analyses of $U, \mathrm{Zr}$. starting materials (Tables I, II); melting and forming of fuel rods; schematic drawing of fuel rod; quality control description; sample photomicrographs of as-fabricated fuel (prior to hydriding)

Ka59. Melting and casting of $U-\mathrm{Zr}$ alloy (how it was done)

Ka59 Tables: fuel element identification and dimensions, pre- and post-hydriding dimensions, density, electrical resistivity, weight, hydrogen and uranium compositions; assembled element dimensions; hydrogen leak rates; "scintillation testing" $\left({ }^{235} \mathrm{U}\right.$ gamma spectrum;

- L-77 reactor neutron scattering to measure hydrogen content - not effective)

Eg59 Schematic drawing of fuel rod

Mi63 Schematic drawing of fuel rod

Ta63 Hydriding process details and hydriding yield (Table 7); general studies of hydrided fuel

Fuel Cladding, Inner Coatings, and Other Non-Fuel Materials:

Ka59 347 SS cladding (three were Hastelloy B: R-7, U-10, X-10), with Solaramic S1435-A, Be end reflectors (those in Hastelloy B had Hastelloy B end caps), incl. end reflector composition data. Cladding tube dimensions and coating thickness

Ro61 Cladding development for hydrogen retention, leading to identification of Hastelloy $N$ and $B$ as the most favorable cladding materials and Solaramic S-1435A as an effective hydrogen barrier

Hu61 Coolant = eutectic NaK (78 wt\% potassium)

Bu64 Solaramic 14-35A coating general description (Table 4.1.1)

Potential Fuel Chemical Reactions:

Potential RCRA-Regulated Materials:

Ta63 SER end reflectors were composed of Be (removed during INEL decladding) 
Quantities of Materials:

See shipping spreadsheets (fuel rods, $U,{ }^{235} \mathrm{U}$ )

Fuel Assembly Identification Methods:

Ka59 Table II diameter data columns distinguish between "numbered end" and "opposite end"

\subsection{SER OPERATIONAL HISTORY}

Core Operating History:

Hu61 Operations chronology (Table IV); total SER history (Fig. 21)

Includes power \& reactivity information, but no neutron data

Be62 Operational report, incl. history (Fig. 16, Table IV)

Mi63 Operations chronology summary

Ja73 Summary of SER operation, operations chronology, analysis of reactor operations.

Core Neutron Flux Profile:

Operation Abnormalities:

Hu61 Scrams (Table V); describes maintenance problems

Be62 Abnormality summary (Table V)

Ja73 Scram summary (Table 10)

Core Shut-Down Date:

Hu61 Final shutdown 19 November 1960

Core Discharge Date:

Be62 SER disassembly started 19.May 1961, completed 13 June 1961

\subsection{SER POST-IRRADIATION PROPERTIES AND EXAMINATION}

Visual Observations:

Mi63 Visual examination - appeared to be no problems with fuel or cladding

Dimensions:

Mi63 Dimensional and density measurements

Metallurgical States of Materials:

Mi63 photomicrograph of hydrided fuel after irradiation

Cladding Defects:

Corrosion or Chemical Contamination:

Hydrogen Effects:

Mi63 hydrogen leak rate

Burnup:

Mi63 Bumup profile plots.

Fission products:

Mi63 Fission gas release (none observed) 


\section{Transuranics:}

(can be calculated from available reactor information)

Activation Products:

Decay Heat Generation:

Radiation Level Decay Curves:

Alpha Contamination:

(not relevant for the declad fuels)

\subsection{SER ON-SITE STORAGE HISTORY}

SNAP fuel elements were stored in air at the Radioactive Materials Disposal Facility (RMDF) in dry storage vaults, in preparation for shipment to INEL following Atomics International Hot Laboratory (AIIL) operations. The AIHL operations included the disassembly of the reactor and core, and the removal and evaluation of the fuel elements. Until cleanup of residual NaK was complete, all AIHL operations were performed in an atmosphere of nitrogen gas, containing no more than $3 \%$ oxygen. There were no wet-storage facilities available at Atomics International. No detailed storage history documentation is available, and storage information is based on personal-recollections of individuals involved in the program.

\subsection{SER SHIPPING RECORDS}

The shipping records for SER fuel shipments to INEL were reviewed in detail. The original records are difficult to read, and were transcribed onto the SER spreadsheet that is reproduced at the end of this section. The spreadsheet lists the fuel rod (unclad), total uranium, and ${ }^{235} \mathrm{U}$ masses for each fuel element, plus the shipping document number, shipment date, Atomics Intemational can number, and probable INEL aluminum can number. The latter is base on document copies received from INEL as part of the current review activity. 54 irradiated STF fuel elements were shipped to INEL, out of 68 original fuel elements. The other 14 include 7 irradiated/sectioned fuel elements and 7 unirradiated fuel elements that were disposed of by other means.

The mass totals shown on the spreadsheet were calculated from the individual recorded fuel element data. They were compared with an SER Fuel Data mass sheet dated 7/27/64. and filed with the shipping records. This comparison shows a slight discrepancy for shipment LAE-JWA-27 (AI. Can No. 14-H), where the data sheet lists the total fuel rod mass as $4337 \mathrm{~g}$, instead of $4339 \mathrm{~g}$ as obtained from the shipping records (with a corresponding total fuel mass for SER of $39023 \mathrm{~g}$ instead of $39025 \mathrm{~g}$ ).

\subsection{SER REFERENCES}

Be62 J. P. Beall and M. W. Hulin, "SNAP-2 Experimental Reactor Operation and Test Program," Atomics International Report NAA-SR-7088 (April 1962) (76 pages)

B159 M. Bloomfield, "Tentative SER Fuel Element Inspection Specification," Atomics International Memorandum NAA-SR-MEMO-4063 (June 1959) (8 pages)

Bu64 G. F. Burdi, Ed., "SNAP Technology Handbook. Volume II. Hybrid Fuels and Claddings," Atomics International Report NAA-SR-8617, Volume II (November 1964) (129 pages) 
Di67 H. M. Dieckamp, "Nuclear Space Power Systems," Atomics International (September 1967) (unpublished book, 388 pages)

Dr60 P. S. Drennan, "Melting and Forming of SER Fuel Rods," Atomics International Report NAA-SR: 4762 (October 1960) (30 pages)

Eg59 R. R. Eggleston and G. L. Schmidt, Ed., "SNAP II. Experimental Reactor Hazards Report," Atomics Intemational Report NAA-SR-3465 (April 1959) (156 pages)

Go67c K. G. Golliher, et al., "SNAP Engineering Test Facility Safety Analysis Report: Addendum for Intrinsic Supercriticality Experiments," Atomics International Technical Data Record NAA-SRMEMO-12614 (November 1967) (80 pages)

Hu61 M. W. Hulin and J.: Beall, Ed., "Preliminary Results of the SNAP 2 Experimental Reactor," Atomics International-Report NAA-SR-5991 (April 1961) (60 pages)

Ja73 A. A. Jarrett, "SNAP 2 Summary Report," Rockwell International, Atomics International Division . Report AI-AEC-13068 (July 1973) (190 pages)

Ka59 .N. H. Katz, "SER Data Report," Atomics International Memo.NAA-SR-MEMO-4722 (December. 1959) (25 pages)

Mi63* J. R. Miller, "Postirradiation Evaluation of SER Fuel Elements," Atomics International Report NAA-SR-8090 (May. 1963) (29 pages)

Re59 E. L. Reed, "SER Fuel Element Specification," Atomics Intemational Internal Letter dated 11 June 1959 (4 pages)

Ro61*.C. J. Romero and S. Elchyshyn, "Cladding Development for SER Fuel Elements," Atomics. Intemational Report NAA-SR-4831 (February 1961) (42 pages)

Ta63 H. Taketani, "Hydriding of SNAP. 2 Fuel Rods," Atomics Intemational Report NAA-SR-5037 (June 1963) (37 pages)

Tu58 R. R. Turk, "Feasibility Report for Fabrication of SNAP II Fuel Elements," Atomics International Memo NAA-SR-MEMO-3083, Rev. II (October 1958) (32 pages)

Wi58 L. A. Wilson, "Evaluation of Required Fuel Loading in the SER," Atomics International Technical Data Record NAA-SR-MEMO-3406 (December 1958) (12 pages)

Wi59 L. A. Wilson, "SNAP II Experimental Reactor Physics Analysis," Atomics International Report NAA-SR-3607 (June 1959) (71 pages) 


\begin{tabular}{|c|c|c|c|c|c|c|c|c|c|c|}
\hline \multirow{2}{*}{$\begin{array}{l}\text { Shipping } \\
\text { Document }\end{array}$} & \multirow{2}{*}{$\begin{array}{c}\text { Shipment } \\
\text { Date }\end{array}$} & \multirow{2}{*}{$\begin{array}{c}\text { Al } \\
\text { Can No. }\end{array}$} & \multicolumn{3}{|c|}{ Fuel Identification } & \multicolumn{3}{|c|}{ Fuol Masses (grams) } & \multirow[b]{2}{*}{ Notes } & Prob. INEL \\
\hline & & & Element & Rod & Location & Unclad & wat U & U-235 & & Can No. \\
\hline \multirow[t]{18}{*}{ CAE-JZA-15 } & $4 / 27 / 66$ & 4 & $5 R-9$ & & & 4342 & 295 & $2 \pi$ & & 4 \\
\hline & & & 9R-5 & & & & & & & \\
\hline & & & M6 & & & & & & & \\
\hline & & & $Y-6$ & & & & & & & \\
\hline & & & $Q-4$ & & & · & & & & . \\
\hline & $\cdot$ & & Q-6 & & & & & & & \\
\hline & & 5 & $Y-7$ & & & 4337 & 298 & 280 & & 4 \\
\hline & & & $z-1$ & & & & & & & \\
\hline & & & $T-8$ & & & & & & & \\
\hline & & & 11R-7 & & & & & & & \\
\hline & & & $9 R-10$ & & & & & & & \\
\hline & & & $5 R-2$ & & & & & & & \\
\hline & & 6 & $R-4$ & & & 4338 & 296 & 278 & & 4 \\
\hline & & & Q-3. & & & & & & & \\
\hline & & & Q-2 & & & & & & & \\
\hline & & & $5 R-3$ & & & & & & & \\
\hline & & & $10 R-10$ & & & & & & & \\
\hline & & & $6 \mathrm{R}-4$ & & & & & & & \\
\hline$\cdot$ & Shipi & lent totals: & 18 & elements & & 13017 & 889 & 835 & & \\
\hline \multirow[t]{19}{*}{ CAE-JZA-2O } & $5 / 25 / 66$ & 3. & 10R-7 & & & 4335 & 296 & 278 & & 5 \\
\hline & & & $6 R-3$ & & & & & & & \\
\hline & & & M-2 & & & & & & & \\
\hline & & & $R-3$ & & & & & & & \\
\hline & & & $Z-7$ & & & & & & & \\
\hline & & & Q-5 & & & & & & & \\
\hline & & 2 & $W-6$ & & & 4337 & 295 & 277 & & 5 \\
\hline & & & 9R-9 & $\cdot$ & & & & & & \\
\hline & & & $11 R-3$ & & & & & & & \\
\hline & & & $T-2$ & & & & & & & \\
\hline & & & $R-1$ & & & & & & & \\
\hline & & . & $5 R-8$ & & & & & & & \\
\hline & & 1 & $x-7$ & & & 4326 & 293 & 275 & & 5 \\
\hline & & & $w-2$ & & & & & & & \\
\hline & & & $Q-1$ & & & & & & & \\
\hline & & & 10R-9 & & & & & & & \\
\hline & & & $9 R-3$ & - & & & & & & \\
\hline & & & $W-1$ & & & & & & & \\
\hline & Shlp! & ent totals: & 18 & elements & & 12998 & 884 & 830 & & \\
\hline
\end{tabular}




\begin{tabular}{|c|c|c|c|c|c|c|c|c|c|c|}
\hline \multirow{2}{*}{$\begin{array}{l}\text { Shipping } \\
\text { Document }\end{array}$} & \multirow{2}{*}{$\begin{array}{c}\text { Shipment } \\
\text { Date }\end{array}$} & \multirow{2}{*}{$\begin{array}{c}\text { Al } \\
\text { Can No. }\end{array}$} & \multicolumn{3}{|c|}{ Fuel Identification } & \multicolumn{3}{|c|}{ Fuel Masses (grams) } & \multirow[b]{2}{*}{ Notes } & \multirow{2}{*}{$\begin{array}{c}\text { Prob. INEL } \\
\text { Can No. }\end{array}$} \\
\hline & & & Element & Rod & Location & Unclad & total U & U-235 & & \\
\hline \multirow[t]{7}{*}{ LAE-JWA-27 } & $9 / 30 / 68$ & 14-H & 347 & & & 723 & 48 & 45 & & SN-2O \\
\hline & & & 347 & & & 722 & 49 & 46 & & \\
\hline & & & $347 \quad \mathrm{U}-1$ & & & 721 & 48 & 45 & & \\
\hline & & & $34711 R-4$ & & & 724 & 50 & 47 & & \\
\hline & & & $347 \quad R-2$ & & & 724 & 49 & 46 & & \\
\hline & & & $347 \quad M-5$ & & & 725 & 51 & 48 & & \\
\hline & Shipm & int totals: & 6 & elements & & $\begin{array}{c}4330 \\
\text { notes be }\end{array}$ & 295 & 277 & & \\
\hline
\end{tabular}

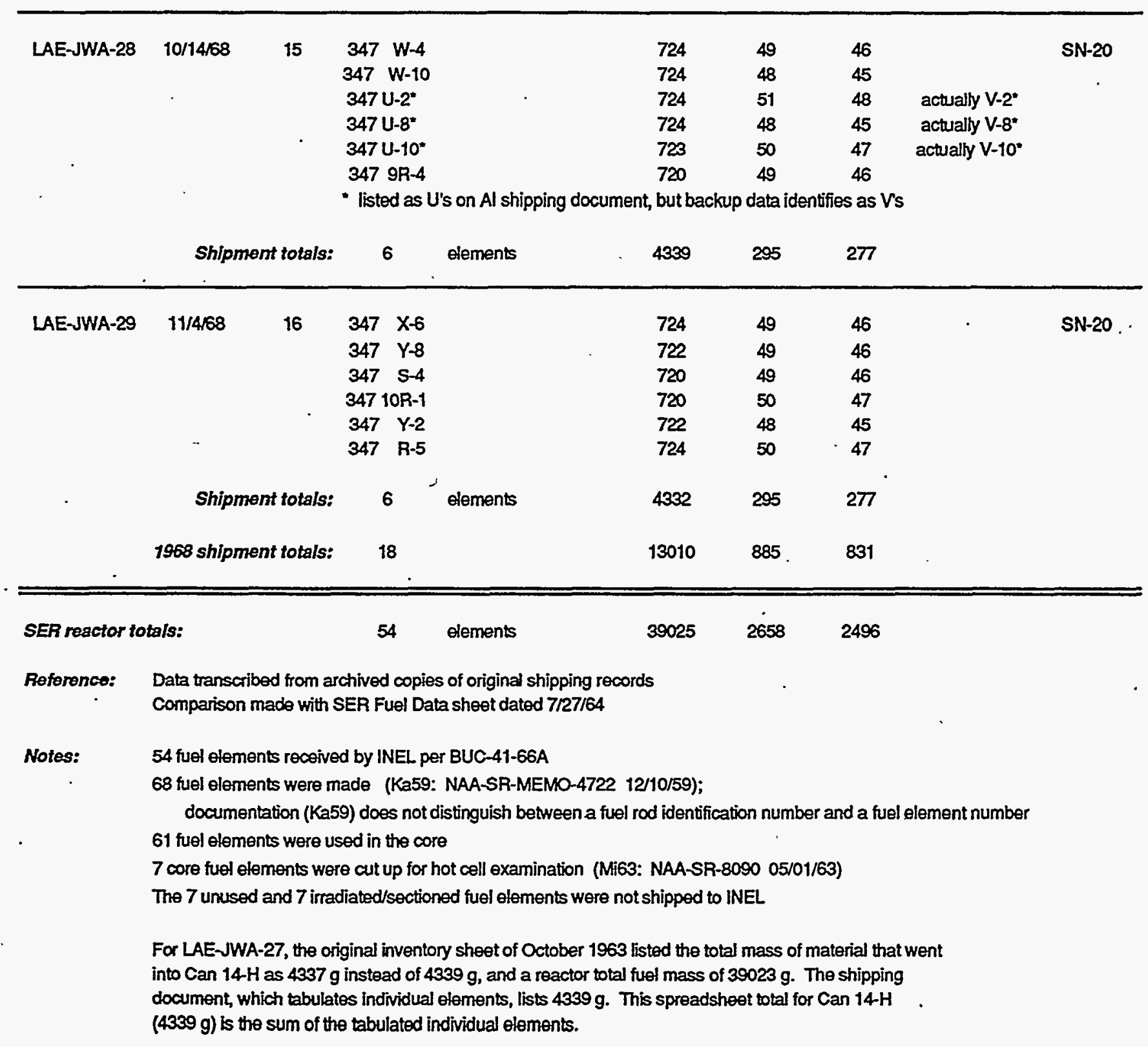




\section{SNAP-2 DEVELOPMENTAL REACTOR (S2DR)}

Date went critical:

- Date of shutdown:

Thermal power:

Thermal energy:

Time at power and temperature:

Operating location:
April 1961 (O165)

December 1962 (0165)

$65 \mathrm{kWt}$

$273,000 \mathrm{kWt}-\mathrm{h}$

$2800 \mathrm{~h}$ at $1200^{\circ} \mathrm{F}, 7700 \mathrm{~h}$ above $900^{\circ} \mathrm{F}$

$2100 \mathrm{~h}$ at $1200^{\circ} \mathrm{F}, 6900 \mathrm{~h}$ above $900^{\circ} \mathrm{F}$ (Di67)

SSFL Building 024

\subsection{S2DR GENERAL DESCRIPTION}

The S2DR was the second-generation SNAP-2 design, which more nearly approximated the detailed requirements of a space reactor (Di67). The SDR core consisted of 37 fuel elements of 11/4-inch diameter containing $10 \mathrm{wt}$. \% uranium and $6.5 \times 10^{22}$. hydrogen atoms $/ \mathrm{cm}^{3}$. The core geometry was similar to that of the SER. A general description is given in Ja73.

\subsection{S2DR REACTOR AND FUEL IDENTIFICATION}

Reactor: . SNAP-2 Developmental Reactor (S2DR)

Also identified as: $\quad$ SNAP Developmental Reactor (SDR)

Core fuel identification: S2DR (same as reactor name).

Reactor designer, builder, operator: Atomics Intemational

Reactor owner: Atomic Energy Commission (now DOE)

Fuel designer, builder: Atomics Intemational

Fuel owner: Atomic Energy Commission (now DOE)

\subsection{S2DR DESIGN REACTOR PHYSICS AND CORE DESCRIPTION}

Fuel Elements/Assemblies: 80 fuel elements fabricated (De62), 37 used in core (De62, Mi64)

Design Neutron Flux:

Design Neutron Energy: Mean neutron fission energy near $0.18 \mathrm{eV}$ (Go67c)

Core Map and Element Locator:

De62 Core map (Fig. 16) - prior to reactor assembly

Mi64 Core map (Fig. 1)

Fe64 Core map (Fig. 3)

0165 Core map with identification of fuel elements for detailed analysis (Fig. 2) 


\subsection{S2DR FUEL FABRICATION INFORMATION}

\section{Fuel Specifications and Drawings:}

De62 Schematic drawing of fuel element (Fig. 1)

Ta63 Non-dimensional fuel element specifications (Table 1)

Bu64 S2DR description (Table 5.2.3), providing nominal design data, plus fuel element schematic drawing

O165 Fuel element schematic drawing

Drawing .7512-22151 "S2DR Fuel Element," in which the fuel rod is Detail-5 (07/61)

\section{Fuel Fabrication and Quality Control:}

Dr61 - Table I: Assembly of fuel element components, including correlation of fuel element number with fuel rod number, top and bottom reflector numbers,

Table II: $\quad$ tube number, and top and bottom end $\quad$ Pre-irradiation hydrogen leak rate data

Table III: $\quad$ Fuel element correlation with total weight and ${ }^{235} \mathrm{U}$ content

Table IV: $\quad$ Fuel element dimensions

Table V: $\quad$ Fuel rod $\mathrm{N}_{\mathrm{H}}$ and density

Table VI: $\quad$ Fuel rod weight, resistivity, surface quality (Zyglo), internal soundness . . (ultrasonic category)

Table VII: Dimensions of finished machined fuel rods

Table VIII: : Pre-hydride uranium content, hardness, weight, and density

Table IX: - Pre-hydride fuel rod dimensions

Table X: $\quad$ Chemical impurity of pre-hydride fuel alloy

Table XI: Dimensions, weight, and density of $\mathrm{BeO}$ end reflectors .

Table XII: - Dimensions of "A" end caps (uncoated).

Table XIII: . Dimensions of " $A$ ". end caps (coated)

Table XIV: Dimensions of " $\mathrm{H}$ " end caps (uncoated)

Table XV: Wall thickness and hardness of tubing (uncoated)

Table XVI: Coating thickness, weight, and $\mathrm{Sm}_{2} \mathrm{O}_{3}$ content

Table XVII: $\quad \mathrm{Sm}_{2} \mathrm{O}_{3}$ concentration in coating

Table XVIII: AI analysis of Hastelloy- $\mathrm{N}$ cladding

De62 80 fuel elements were produced, of which 37 were used. An additional 9 were used in dry critical experiments and removed. (Thus 46 were irradiated.) Table II identifies all 80 elements, their corresponding fuel rod numbers, and their end use, including those not used in core. This table also gives $\mathrm{N}_{\mathrm{H}}$, hydrogen leak rate, and longitudinal bow (TIR, total indicator reading). Document gives fuel element general assembly process.

Ta63 Chemical analyses of $U$ metal, $\mathrm{Zr}$ sponge, and fuel alloy; provides hydriding process details and hydriding yield (Table 7). General studies of hydrided fuel.

Fuel Cladding, Inner Coatings, and Other Non-Fuel Materials:

De62 Cladding identification, composition, tensile properties; coating identified as Solaramic S-1435-SM2

Bu64 Solaramic 14-35A coating general description (Table 4.1.1); S-1435-SM2 refers to addition of $\mathrm{Sm}_{2} \mathrm{O}_{3}$ poison

Potential Fuel Chemical Reactions: 


\section{Potential RCRA-Regulated Materials:}

Ta63 S2DR end reflectors were composed of $\mathrm{BeO}$ (removed during INEL decladding)

\section{Quantities of Materials:}

See shipping spreadsheets (fuel rods, $U,{ }^{235} \mathrm{U}$ )

Dr61 Total element weights in Table III

Fuel Assembly Identification Methods:

Mi64 Element numbers scribed on end caps, as shown in Figs. 3 and 6

\subsection{S2DR OPERATIONAL HISTORY}

\section{Core Operating History:}

Fe64 Overall operations history, summarized in Table 4

O165 Total operating history timeline (Fig. 3); total energy release of 272,900 kWh; peak fuel temperature $1279^{\circ} \mathrm{F}$

Ja73 Summary of S2DR operation, operations chronology, analysis of reactor operations

\section{Core Neutron Flux Profile:}

Operation Abnormalities:

Fe64 Operation abnormalities (Table 5)

O165 Reactor shutdown for maintenance in December 1961, February 1962; air-blast heat exchanger failures in April and July 1962; shutdown for suspected NaK leak in September 1962 (none found)

Ja73 History of operation abnormalities

\section{Core Shut-Down Date:}

O165 End of reactor operation December 1962

\section{Core Discharge Date:}

O165 Reactor disassembled in the first half of calendar year 1963

\section{6 . S2DR POST-IRRADIATION PROPERTIES AND EXAMINATION}

Reference 0163 provides the hot cell examination requirements of S2DR fuel elements (planning document), and identifies (by element number) the six fuel elements selected for post-irradiation examination. Reference Mi64 is the detailed post-irradiation analysis report, and 0165 is a final release yersion of Mi64. It contains visual observations and photographs, metallography, axial and radial gamma scans, fuel element dimensions, hydrogen leak rates, and fission gas release, for the fuel elements, rods, and cladding.

Visual Observations:

Mi64 Visual observations before fuel element disassembly, for 8 selected fuel rods; included photographs of typical findings.

Mi64 Fuel rod observations following decladding of selected elements (Fig. 17-20). 


\section{Dimensions:}

Mi64 Post-irradiation fuel element dimensions for selected elements (Table I - V)

Mi64 Radial dimensional growth of fuel rod (Table VIII); fuel rod densities (Table IX)

. Metallurgical States of Materials:

Mi64 Fuel rod and cladding photomicrographs (Fig. 23 - 39)

Cladding Defects:

Mi64 Photomicrographs (no obvious defects)

Corrosion or Chemical Contamination:

Mi64 Photographs (Figures 6-9) indicate chemical reactions at the external cladding surface of selected fuel elements.

Hydrogen Effects:

Mi64 Hydrogen leak rates of selected fuel elements (Table VII)

Mi64 Hydrogen analysis of selected fuel rods (Table X)

Burnup:

- Mi64 Burnup analyses (Section B.2.), based on fission gas analysis ( ${ }^{85} \mathrm{Kr}$ activity).

01650.027 metal-atom \% bumup

Fission products:

Mi64 Longitudinal (Fig. 11, 12) and diametrical (Fig. 22A, B) gamma scan traces and summary (Table VI); analyzer set to counting peak of ${ }^{95} \mathrm{Zr}$ and used to obtain relative fuel bumup.

Transuranics:

(can be calculated from available reactor information)

Activation Products:

Decay Heat Generation:

Radiation Level Decay Curves:

Alpha Contamination:

(not relevant for the declad fuels)

\subsection{S2DR ON-SITE STORAGE HISTORY}

The reactor was disassembled in the first half of calendar year 1963 (O165). Reference 0163 addresses the 6 elements stored at the Radioactive Materials Disposal Facility (RMDF) prior to detailed postirradiation examination at the Atomics International Hot Laboratory (AIHL). SNAP fuel elements were stored in air at the RMDF in dry storage vaults following removal from the AIHL in preparation for shipment to INEL. There were no wet-storage facilities available at Atomics International. No detailed storage history documentation is available. The only fuel disassembly that took place was for hot cell examination, which is covered in the post-irradiation examination section. 


\subsection{S2DR SHIPPING RECORDS}

The shipping records for the S2DR fuel shipments to INEL were reviewed in detail. The original records are difficult to read, and were transcribed onto the S2DR spreadsheet that is reproduced at the end of this

- section. The spreadsheet lists the core location, fuel rod identification, unclad fuel rod mass, total uranium mass, and ${ }^{235} \mathrm{U}$ mass for each fuel element, plus the shipping document number, shipment date, Atomics International can number, and probable INEL aluminum can number. The latter is based on document copies received from INEL as part of the current review activity. The fuel rod identifications and fuel element core locations are from Reference De62. A total of 37 irradiated S2DR fuel elements were shipped to INEL.

The mass totals shown on the spreadsheet were calculated from the individual recorded fuel element data. They were compared with, and agree with, an S2ER Fuel Data mass sheet dated 7/27/64 and filed with the shipping records.

\subsection{S2DR REFERENCES}

Bu64 G. F. Burdi, Ed., "SNAP Technology Handbook. Volume II. Hybrid Fuels and Claddings," Atomics Intemational Report NAA-SR-8617, Volume II (November 1964) (129 pages)

De62* W. F. Dennison and T. S. Jakobowski, "Assembly of S-2 DR Fuel Elements," Atomics International Report NAA-SR-7048 (December 1962) (26 pages)

Di67 .H. M. Dieckamp, "Nuclear Space Power Systems," Atomics Intemational (September 1967)

Dr61 P. S. Drennan and W. Sawicky, "Summary of Test Data for S-2-DR Fuel Elements," Atomics International Technical Data Record NAA-SR-MEMO-6745 (September 1961) (32 pages)

Fe64 L. D. Felten, et al., "Final Report on the SNAP 2 Development Reactor (S2DR) Test Program," Atomics International Report NAA-SR-8295 (April 1964) (156 pages)

Go67c K. G. Golliher, et al., "SNAP Engineering Test Facility Safety Analysis Report: Addendum for Intrinsic Supercriticality Experiments," Atomics International Technical Data Record NAA-SRMEMO-12614 (November 1967) (80 pages)

Ja73 A. A. Jarrett, "SNAP 2 Summary Report," Rockwell International, Atomics International Division Report AI-AEC-13068 (July 1973) (190 pages)

Mi64 K. J. Miller, "Postirradiation Examination of the SNAP-2 Developmental Reactor Fuel Elements," Atomics Intemational Technical Data Record NAA-SR-MEMO-9753 (April 1964) (74 pages)

O163 P. S. Olson, "Hot Cell Examination Requirements of S2DR Fuel Elements," Atomics International Technical Data Record NAA-SR-8716 [NAA-SR-TDR-8716] (July 1963) (8 pages)

O165* P. S. Olson, " Evaluation of Fuel Elements from SNAP 2 Developmental Reactor Core," Atomics Intemational Report NAA-SR-9648 (January 1965) (35 pages)

Ta63 H. Taketani, "Hydriding of SNAP 2 Fuel Rods," Atomics International Report NAA-SR-5037 (June 1963) (37 pages) 


\begin{tabular}{|c|c|c|c|c|c|c|c|c|c|c|}
\hline \multirow{2}{*}{$\begin{array}{l}\text { Shipping } \\
\text { Document }\end{array}$} & \multirow{2}{*}{$\begin{array}{l}\text { Shipment } \\
\text { - Date }\end{array}$} & \multirow{2}{*}{$\begin{array}{c}\text { Al } \\
\text { Can No. }\end{array}$} & \multicolumn{3}{|c|}{ Fuel Identification } & \multicolumn{3}{|c|}{ Fuel Masses (grams) } & \multicolumn{2}{|r|}{ Prob. INEl } \\
\hline & & & Element & Rod & Location & Unclad & total U & $\mathrm{U}-235$ & Notes & Can No. \\
\hline \multirow[t]{7}{*}{ CAE-JZA-13 } & $4115 / 56$ & 2 & E-22 & $515-3$ & N-8 & 1142 & 113 & 105 & & 1 \\
\hline & & & $E-26$ & $515-5$ & $\mathrm{II}-2$ & 1141 & 113 & 105 & & \\
\hline & & & $E-30$ & $517-3$ & $11-5$ & 1141 & 113 & 105 & & \\
\hline & & & E-34 & $518-2$ & $\|-4$ & 1140 & 113 & 105 & & \\
\hline & & & $E-38$ & $518-1$ & $111-6$ & 1140 & 113 & 105 & & \\
\hline & & & E-39 & $520-2$ & $1 V-6$ & 1143 & 113 & 105 & & \\
\hline & \multicolumn{2}{|c|}{ Shlpment totals: } & 6 & elements & & 6847 & 678 & 630 & & \\
\hline \multirow[t]{7}{*}{ CAE-JZA-14 } & \multirow[t]{6}{*}{$4 / 20166$} & \multirow[t]{6}{*}{7} & $E-51$ & $520-7$ & IV-18 & 1141 & 113 & 105 & & \multirow[t]{7}{*}{3} \\
\hline & & & $E-60$ & $520-3$ & $I V-1$ & 1153 & 114 & 106 & & \\
\hline & & & $E-65$ & $511-4$ & IV-16 & 1153 & 114 & 106 & & \\
\hline & & & E-73 & $512-6$ & $\mid I I-1$ & 1137 & 113 & 105 & & \\
\hline & & & $E-79$ & $511-3$ & IV-17 & 1130 & 113 & 105 & & \\
\hline & & & $E-76$ & $526-1$ & $|I|-12$ & 1140 & 113 & 105 & & \\
\hline & \multicolumn{2}{|c|}{ Shipment totals: } & 6 & elements & & 6863 & 680 & 632 & & \\
\hline \multirow[t]{7}{*}{ CAE-JZA-16 } & \multirow[t]{6}{*}{$5 / 2 / 66$} & \multirow[t]{6}{*}{5} & E-15 & $515-1$ & IV-12 & 1143 & $i 13$ & 105 & & \multirow[t]{7}{*}{2} \\
\hline & & & E-35 & $519-7$ & $111-4$ & 1142 & 113 & 105 & & \\
\hline & & & $E-21$ & $518-6$ & $1 \mathrm{~V}-7$ & 1142 & 113 & 105 & & \\
\hline & & & E-32 & $517-1$ & IV-9 & 1142 & 113 & 105 & & \\
\hline & & & $E-67$ & $516-3$ & III-5 & 1141 & 113 & 105 & & \\
\hline & & & $E-69$ & $513-6$ & IV-10 & 1155 & 115 & 107 & & \\
\hline & \multicolumn{2}{|c|}{ Shipment totals: } & 6 & elements & & 6865 & 680 & 632 & & \\
\hline \multirow[t]{7}{*}{ CAE-JZA-17 } & \multirow[t]{6}{*}{$5 / 5 / 66$} & \multirow[t]{6}{*}{6} & E-74 & $510-4$ & $111-3$ & 1140 & . 113 & 105 & & \multirow[t]{6}{*}{3} \\
\hline & & & E-72 & $509-3$ & $111-9$ & 1136 & 113 & 105 & & \\
\hline & & & $E-14$ & $519-2$ & $\|-1$ & 1142 & 113 & 105 & & \\
\hline & & & $E-31$ & $517-5$ & $H I-2$ & 1141 & 113 & 105 & & \\
\hline & & & $E-77$ & $513-5$ & $\mathrm{~N}-3$ & 1141 & 113 & 105 & & \\
\hline & & & E-66 & $511-6$ & $1 V-4$ & 1155 & 115 & 107 & & \\
\hline & \multicolumn{2}{|c|}{ Shipment totals: } & 6 & elements & & 6855 & 680 & 632 & & . \\
\hline \multirow[t]{7}{*}{ CAE-JZA-18 } & $5 / 9 / 66$ & 1 & $E-37$ & $537-3$ & III-7 & 1143 & 113 & 105 & & 1 \\
\hline & & & $E-8$ & $515-4$ & $111-8$ & 1141 & 113 & 105 & & \\
\hline & & & E-58 & $516-2$ & $1-1$ & 1141 & 113 & 105 & & \\
\hline & & & $E-33$ & $520-5$ & IV-13 & 1142 & 113 & 105 & & \\
\hline & & & $E-49$ & $527-1$ & IV-5 & 1142 & 113 & 105 & & \\
\hline & & & $E-18$ & $517-6$ & $\mid V-11$ & 1141 & 113 & 105 & & \\
\hline & Shipn & ent totals: & 6 & elements & & 6850 & 678 & 630 & & \\
\hline CAE-JZA-19 & $5 / 12 / 66$ & 4 & $E-48$ & $515-6$ & $11-3$ & 1028 & 102 & 95 & & 2 \\
\hline & & & E-50 & $519-6$ & IV-15 & 1027 & 102 & 95 & & \\
\hline & Shipn & ent totals: & 2 & elements & & 2055 & 204 & 190 & & \\
\hline
\end{tabular}




\begin{tabular}{ccccccccccc}
\hline $\begin{array}{c}\text { Shipping } \\
\text { Document }\end{array}$ & $\begin{array}{c}\text { Shipment } \\
\text { Date }\end{array}$ & $\begin{array}{c}\text { Al } \\
\text { Can No. }\end{array}$ & Element & Rod & Location & Unclad & botal U & U-235 & Notes & Prob. INEL \\
Cari No.
\end{tabular}

S2DR reactor fotals: $\quad 37 \quad$ elements $\quad 42039 \quad 4165 \quad 3871$.

Beferences: Data transcribed from archived copies of original shipping records Mass sums compared with (and agree with) S2DR Fuel Data sheet dated 7/27/64 Fuel rod identifications from De62 (NAA-SR-7048, 12/15/62, Table II)

Notes: $\quad 37$ fuel olements shipped to INEL 


\section{SNAP-10A GROUND TEST REACTOR (10FS-3).}

Date went critical:

Date of shutdown:

Thermal power:

Thermal energy:

Electric power:

Electric enèrgy:

Time at power and temperature:

Operating location:
January 1965

March 161966 (Go67a)

$40 \mathrm{kWt}$ nominal

$382,944 \mathrm{kWt}-\mathrm{h}$

402 Watts

$4028 \mathrm{~kW}-\mathrm{h}$

$10,005 \mathrm{~h}(417 \mathrm{~d})$ above $900^{\circ} \mathrm{F}$

SSFL Building 024

\subsection{FS-3 GENERAL DESCRIPTION}

The SNAP-10A reactor system utilized SNAP-2 reactor technology with minimum modifications. The . reactor core consisted of 37 hydrided zirconium-uranium alloy fuel elements clad in the nickel-base alloy Hastelloy $\mathrm{N}$. The fuel elements were positioned and constrained in the core by upper and lower grid plates. They were arrayed in a hexagonal pattem within a circular reactor vessel, and surrounded by a beryllium reflector structure.

- The hydrided zirconium-uranium alloy fuel material alloy served both as fuel and moderator. The unhydrided alloy contained a nominal $10 \mathrm{wt} \%$ uranium and was hydrided to a hydrogen concentration of $6.35 \mathrm{x} \cdot 10^{22}$ atoms of hydrogen $/ \mathrm{cm}^{3}$, which is slightly. less than the hydrogen concentration in cold - water. The uranium was $93 \%$ enriched in ${ }^{235} \mathrm{U}$. This material was formed into rods of $30.7 \mathrm{~mm}(1.21$ in.) diameter and $31.1 \mathrm{~cm}$ (12.25 in.) length and was canned in Hastelloy-N cladding tubes. The cladding. tubes were $31.75 \mathrm{~mm}$ OD and had a wall thickness of $0.38 \mathrm{~mm}(0.015 \mathrm{in})$. Intemal surfaces of the cladding tubes were coated with a $0.076-\mathrm{mm}(0.003-\mathrm{in}$.) layer of ceramic glass material. This coating acted as a barrier to hydrogen leakage from the fuel. The ends of the fuel elements were sealed with end caps of Hastelloy- $\mathrm{N}$ material welded to the cladding tube. The end pins that positioned and held the elements between the grid plates were an integral part of the end caps. Each fuel element weighed 1.5 $\mathrm{kg}(3.4 \mathrm{lb})$ and had an overall length, including end pins, of $32.6 \mathrm{~cm}(12.82 \mathrm{in}$.).

Each unclad fuel rod contained approximately $128 \mathrm{~g}$ of ${ }^{235} \mathrm{U}, 11.8 \mathrm{~g}$ of ${ }^{238} \mathrm{U}, 24.6 \mathrm{~g}$ of hydrogen, and $1215 \mathrm{~g}$ of zirconium. Its total weight was approximately $1380 \mathrm{~g}$. A small amount of carbon (approximately $0.15 \mathrm{wt} \%$ ) was added as a grain refiner to. produce an optimum microstructure, and thus increase yield during hydriding. The fuel was a hard, semibrittle material with a machined surface and a metallic appearance. All edges of the fuel rod were rounded to prevent damage to the ceramic hydrogen barrier during assembly and handling of the fuel element.

The ceramic glass barrier, commercially known as Solaramic 1435-SM2, was composed primarily of oxides of aluminum, silicon, titanium, manganese, and barium with smaller amounts of sodium, lithium, and potassium. This ceramic coating was generally applied in three firings. In the last two firings, a small quantity of the bumable poison samarium oxide $\left(\mathrm{Sm}_{2} \mathrm{O}_{3}\right)$ was incorporated into the coating. The nominal samarium oxide loading was $3 \mathrm{mg} / \mathrm{cm}$. Depletion of this material inserted reactivity at the proper rate to provide more than one year of stable reactor operation without complex mechanical control rods.

One end cap of the fuel element was welded to a cladding tube before the ceramic barrier was applied. - After the ceramic barrier had been fired, a fuel rod was inserted into the cladding tube. The cladding tube was then sealed against hydrogen loss by the insertion of a ceramic-coated blend cup. The hydrogen 
barrier was made complete by locally heating the cladding tube and blend cup to blend the ceramic surfaces together. Following the blending operation, an end cap was welded to the cladding tube, covering

the blend cup. No play existed between the fuel rod and the cladding tube.

General descriptions of the SNAP 10A system are given in references Mi65, Di67, St67, AN76, and An83.

\subsection{FS-3 REACTOR AND FUEL IDENTIFICATION}

Reactor:

Also Identified As:

SNAP 10A Ground Test Reactor (10FS-3)

SNAP 10A FS-3 Ground Test System

SNAP 10 Flight System 3 Reactor (S10FS-3)

Core fuel Identification: $10 \mathrm{FS}-3$ (same as reactor name)

Note (Sa64d): fuel elements were originally fabricated for three SNAP 10A cores with core 'designations FS-1, FS-3, and FS-4. Data from FS-1 operation showed that SNAP 10A operating characteristics could be improved. with the fabrication of some new low- $\mathrm{N}_{\mathrm{H}}$, high- $\mathrm{Sm}_{2} \mathrm{O}_{3}$ fuel elements and the redistribution. of elements in the three cores. The revised cores were redesignated as the FS-3, FS-4, and FS-5 cores. Thus the core designations for the fuel elements in the original data packages do not correspond to the final distribution of fuel elements. See below under Fuel Fabrication for identification of those fuel elements incorporated in the final 10FS-3 core.

Reactor designer, builder, operator: Atomics Intemational

Reactor owner:' Atomic Energy Commission (now DOE)

Fuel designer, builder: Atomics Intemational

Fuel owner:' Atomic Energy Commission (now DOE)

\subsection{FS-3 DESIGN REACTOR PHYSICS AND CORE DESCRIPTION}

Fuel elements/assemblies: 37 fuel elements (Mi65, Go67a)

Design neutron flux:

Design neutron energy: Mean neutron fission energy near $0.18 \mathrm{eV}$ (Go67c)

Core map and element locator:

Mi65 Fuel loading table (Table 6) and core loading configuration (Fig. 7)

Go67, Go67a, Go67b:

Core maps showing.locations of individual fuel elements (Fig. 1); Go67a includes table identifying fuel element numbers and core locations

\subsection{FS-3 FUEL FABRICATION INFORMATION}

Fuel specifications and drawings:

Sa64, Sa64a, Sa64b, Sa64c, Sa64d:

Reference the engineering drawings and the engineering design specifications for the fuel elements, fuel rods, and raw materials (such as the cladding materials)

Go67 Sketch of fuel element with nominal design information (Fig. 2, Table 1) 


\section{Go67a, Go67b:}

Schematic of the fuel element (Fig. 2); fuel element design criteria (Table 1; probably average of the 37 in-core elements)

Drawing 7580-18020 Drawing for fuel elements 136, 150, 190

Drawing 7573-18002 "Element Assembly-10A Fuel" (04/63; covers other 34 fuel elements)

Drawing 7573-18004 "Rod - Fuel Element"

\section{Fuel fabrication and quality control:}

Bu64 General fuel element information and schematic diagram

Ki63 Melting, casting, and extrusion process procedures for SNAP 10A and $2 \mathrm{ZrU}$ fuel materials

Sa63 Quality control planning document for fuel cladding, fuel rod, and fuel element testing and inspection. Contains examples of all source data forms prepared.

Ca63a, Ar63:

Sequential manufacturing planning sheets for fuel cladding, fuel rod; and fuel element fabrication. These documents complement Sa63. They reference engineering drawings and specifications for the SNAP 10A fuel.

Sa64, Sa64a, Sa64b, Sa64c, Sa64d:

Fabrication quality control (test and inspection) data packages for the SNAP 10A fuel. elements used for the FS-1, FS-3, FS -4, and FS-5 cores. These data packages cover the raw materials through the finished fuel elements. Examples include dimension data, chemistry, hydrogen leak rate, raw materials traceability, visual and non-destructive testing data, and process traceability. Reports Sa64, Sa64a, Sa64b, and:Sa64c contain fuel element pre-assembly core loading assignments for the FS-1, FS-3, and FS-4 cores that were later changed. For example, Sa64b covers the fuel elements for the originally planned FS-3 core, none of which were used in the final 10FS-3 core.

Sa64d:

Data obtained from the FS-1 System test showed that the long-term operating characteristics of the SNAP $10 \mathrm{~A}$-reactors could be improved by increasing the $\mathrm{Sm}_{2} \mathrm{O}_{3}$. content and decreasing slightly the average $\mathrm{N}_{\mathrm{H}}$ of the core. This required fabrication of several new low- $\mathrm{N}_{\mathrm{H}}$, high-Sm $\mathrm{Sm}_{2} \mathrm{O}_{3}$ fuel elements (including 525,528 , and 529), and the redistribution of elements in the FS-1, -3 , and -4 cores. These cores were then redesignated as the FS-3, -4 , and -5 cores, respectively.

A summiary of the fuel elements used in the 10FS-3 ground-test reactor (from Sa64d) and the appropriate reference for the data package for each is given in the table below:

Fuel cladding, inner coatings, and other non-fuel materials:

Sa64, Sa64a, Sa64b, Sa64c, Sa64d:

Full data packages on all fuel element materials

Bu64 Hastelloy-N cladding with chromized surfaces; Solaramic S14-35A ceramic coating on cladding inside surfaces

\section{Potential fuel chemical reactions:}

Potential RCRA-regulated materials:

Quantities of materials:

See shipping spreadsheets (fuel rods, $U,{ }^{235} \mathrm{U}$ ) 
Identifications and Data:Package References for the 10FS-3 Fuel Elements

\begin{tabular}{||c|c|c|c|c|c|c|c|c||}
\hline $\begin{array}{c}\text { Core } \\
\text { Position }\end{array}$ & $\begin{array}{c}\text { Element } \\
\text { No. }\end{array}$ & Reference & $\begin{array}{c}\text { Core } \\
\text { Position }\end{array}$ & $\begin{array}{c}\text { Element } \\
\text { No. }\end{array}$ & Reference & $\begin{array}{c}\text { Core } \\
\text { Position }\end{array}$ & $\begin{array}{c}\text { Element } \\
\text { No. }\end{array}$ & Reference \\
\hline 1 & 422 & Sw64a & 14 & 365 & Sw64a & 27 & 190 & Sw64 \\
2 & 486 & Sw64a & 15 & 421 & Sw64a & 28 & 150 & Sw64 \\
3 & 529 & Sw64d & 16 & 441 & Sw64a & 29 & 337 & Sw64a \\
4 & 484 & Sw64a & 17 & 459 & Sw64a & 30 & 350 & Sw64a \\
5 & 528 & Sw64d & 18 & 336 & Sw64a & 31 & 349 & Sw64a \\
6 & 440 & Sw64a & 19 & 334 & Sw64a & 32 & 338 & Sw64a \\
7 & 525 & Sw64d & 20 & 345 & Sw64a & 33 & 439 & Sw64a \\
8 & 482 & Sw64a & 21 & 136 & Sw64 & 34 & 442 & Sw64a \\
9 & 331 & Sw64a & 22 & 333. & Sw64a & 35 & 348 & Sw64a \\
10 & 332 & Sw64a & 23 & 479 & Sw64a & 36 & 364 & Sw64a \\
11 & 456 & Sw64a & 24 & 419 & Sw64a & 37 & 352 & Sw64a \\
12 & 435 & Sw64a & 25 & 390 & Sw64a & &. & \\
13 & 418 & Sw64a & 26 & 393 & Sw64a & & & . \\
\hline
\end{tabular}

Fuel assembly identification methods:

Go67 Fuel elements were scribed to show reactor orientation. with respect to centerline before removal

Drawing 7573-18004 calls out identification by electric etching on the side of the rod

\subsection{FS-3 OPERATIONAL HISTORY}

Core Operating History:

Mi65 Report on first 90 days of power operation; graph of core thermal power vs. time (Fig. 24), decreasing from $\sim 41 \mathrm{kWt}$ to $\sim 37 \mathrm{kWt}$

Go67a 10,028 hours of continuous operation; $970^{\circ} \mathrm{F}$ coolant outlet temperature

St67 Systein operations summary (Tables 18,19 )

Core neutron flux profile:

Operation abnormalities:

Core shut-down date:

Go67a March 16, 1966

Core discharge date:

D067 Reactor core removed from facility and placed in shipping cask on May 21, 1966 


\section{6 - 10FS-3 POST-IRRADIATION PROPERTIES AND EXAMINATION}

Available source data include extensive individual element-by-element fuel element data trace files for gamma scans, hydrogen retention, etc. These data are contained in individual file folders rather than in report format. Also included in these files are several original photographs and negatives.

References D067 and Kr67 describe the disassembly and post-irradiation examination of the reactor. components, including metallography, for those reactor components other than the fuel.

Go67. All 37 fuel element subjected to post-irradiation screening examination. On removal from the core, each fuel element was cleaned with Dowanol to remove residual $\mathrm{NaK}$, in a nitrogen atmosphere. 6 elements were selected for detailed post-irradiation examination: $442,331,529$, 440,482 , and 422; results given for 422,331 , and 529 .

Go67a Post-irradiation screening examination results

Go67b Post-irradiation detailed (destructive) examination of six selected fuel elements; elements 422 , 331 , and 529 were declad

\section{Visual observations:}

- Go67 Visual examination results, concluding that there were apparent cladding or weld defects.

Go67a Photographs of typical fuel element surfaces (Fig. 10 - 12); Fig. 12 shows identification of the fuel element number.

Go67b Photographs of typical fuel element surfaces

Dimensions:

Go67 Summary of fuel element length (Table 2) and diameter (Table 3) change data

- Go67a Summary of fuel element length (Table 2) and diameter (Table 3) change data; detailed fuel element dimensional data (Appendix A)

Go67b Declad fuel rod dimension and density measurements (Figs.. 4-6, Appendix A)

Metallurgical states of materials:

: Go67b Fuel metallography for elements $331,529,422$; some examples of minor microcracking (not considered significant)

\section{Cladding defects:}

. Go67 No defects or unexpected results were observed, and the examination supported the conclusion that all the fuel elements completed reactor operation in good condition; descriptions of metallography for selected elements

Go67b Cladding metallography (Fig: 8); no visual signs of damage

Corrosion or chemical contamination:

Go67b Evidence of light contact of fuel-to-coating along the side of the fuel rods in some areas; as would be expected where rods and cladding tubes were not held straight throughout their lifetimes

Hydrogen effects:

Go67 Hydrogen analysis results for 3 detailed-examination elements

Go67b Hydrogen analysis results for 3 detailed-examination elements 


\section{Burnup:}

Go67 Fuel burnup for fuel element 422 (Table 5), including mass spectrographic results $(0.0177$ to 0.0235 metal-atom $\%$ )

Go67b Fuel bumup for fuel element 422 (Table 3), based on gamma scan (Fig. 7)

- Transuranics:

(can be calculated from available reactor information)

Fission products:

G067 Fission gas sampling from fuel element 440; gamma scan data to count. ${ }^{95} \mathrm{Zr}$ activity, summarized by core location (Fig. 13) and including typical gamma scan (Fig. 12)

Go67a Typical gamma scan (Fig. 13; same as Go67); · core map showing gamma scan activity of each fuel element (Fig. 14)

Go67b Fission gas sampling from fuel element 440

Activation products:

Decay heat generation:

Radiation level decay curves:

: Do67 Radiation levels of system components at time of disassembly; core radiation level approximately $200 \mathrm{mr} / \mathrm{h}$ 'general', $400 \mathrm{mr} / \mathrm{h}$ maximum 1 inch from bottom, and $50 \mathrm{mr} / \mathrm{h}$ maximum at 1 meter

Alpha contamination:

(not relevant for the declad fuels)

\subsection{FS-3 ON-SITE STORAGE HISTORY}

$\therefore \quad$ The reactor core was removed from the SNAP SETF facility 2 months after shutdown and transferred to the AI Hot Laboratory for post-irradiation examination (D067). A photograph of the intact 10FS-3 reactor ' assembly as received at the AI. Hot Laboratory is reproduced in Ref. Go67a. The only fuel disassembly that took place was for hot cell examination, which is covered in the post-irradiation examination section. The SNAP fuel elements were stored in air at the RMDF in dry storage vaults following Hot Laboratory examination, in preparation for shipment to INEL. There were no wet-storage facilities available at Atomics Intemational. No detailed storage history documentation is available.

\subsection{FS-3 SHIPPING RECORDS}

The shipping records for the 10FS-3 fuel shipments to INEL were reviewed in detail. The original records are difficult to read, and were transcribed onto the 10FS-3 spreadsheet that is reproduced at the end of this section. The spreadsheet lists the core location, fuel rod identification, unclad fuel rod mass, total uranium mass, and ${ }^{235} \mathrm{U}$ mass for each fuel element, plus the shipping document number, shipment date, Atomics International can number, and probable INEL aluminum can number. The latter is base on document copies received from INEL as part of the current review activity. A total of 37 irradiated 10FS-3 fuel elements, of which 4 were declad and/or sectioned, were shipped to.INEL.

The shipping documents have typographical errors for five fuel elements: E-332 (recorded as E-322), E421 (recorded as E-42), E-338 (recorded as E-388), E-136 (recorded as E-316), and E-442 (recorded as $\mathrm{E}-440)$. Our corrected identification is based on fuel element number comparisons with documentation. 
for fuel element core allocations, as tabulated in the final QA data package (Sa64d) and in the postirradiation screening examination reports (G067a). Fuel rod identification numbers were obtained from the fuel element QA data packages (Sa64, Sa64a, Sa64d).

The mass totals shown on the spreadsheet were calculated from the individual recorded fuel element data.

- They were compared with the 10FS-3 Fuel Data mass summary sheet that was filed with the shipping documents. This comparison showed one 1-g mass discrepancy, for ${ }^{235} \mathrm{U}$ in $\mathrm{AI}$ Can No. 13, which has not been resolved. The 10FS-3 Fuel Data summary sheet also contains a few identified recording errors: the total material available included 33 (not 34) complete elements, and ID \#18 (AI Can No. 18, as identified on the 10FS-3 Fuel Data summary sheet) included element E529 (not element E524).

\subsection{FS-3 REFERENCES}

AN76 Anonymous, "Zirconium Hydride (SNAP) Reactor Space Power Programs. Summary of Major Activities and Accomplishments," Rockwell Intemational Energy Systems Group (June 1976)

An83 R. V. Anderson, et al., "Space Reactor Electric Systems. Subsystem Technology Assessment," Rockwell International Energy Systems Group Report ESG-DOE-13398 (March 1983)

Ar63 J. R. Armstrong, et al., "SNAP 10 A FS-3, -4, and -5 Fabrication Process Sheets and Auxiliary Forms," Atomics Intemational Technical Data Record NAA-SR-MEMO-8809 (July 1963) (41 pages)

Bu64 G. F. Burdi, Ed., "SNAP Technology: Handbook. Volume II. Hybrid Fuels and Claddings," Atomics International Report NAA-SR-8617, Volume II (November 1964) (129 pages)

Ca63a D. C. Campbell, et al., "SNAP 10A-FS-1 Fabrication Process Sheets and Auxiliary.Forms," - Atomics Intemational Technical Data Record NAA-SR-MEMO-8272 (February 1963) (37 pages)

Di67 . .H. M. Dieckamp; "Nuclear Space Power Systems," Atomics Intemational (September 1967) (unpublished book, 388 pages)

Do67 J. P. Dooley and J. P. Beall, "The Disassembly and Postoperation Component Examination of the SNAP 10A FS-3," Atomics International Report NAA-SR-12504 (September 1967) (70 pages)

Go67* T. A. Golding, "Post-Operation Evaluation of Fuel Elements from the SNAP 10 Flight System 3 Reactor," Atomics Intemational Report NAA-SR-12031 (September 1967) (41 pages)

Go67a T. A. Golding, "Post-Irradiation Screening Examination of the S10FS-3 Fuel Elements," Atomics Intemational Technical Data Record NAA-SR-MEMO-12338 (February 1967) (29 pages)

Go67b T. A. Golding, "Post-Irradiation Examination of Selected S10FS-3 Fuel Elements," Atomics International Technical Data Record NAA-SR-MEMO-12341 (June 1967) (28 pages)

Go67c K. G. Golliher, et al., "SNAP Engineering Test Facility Safety Analysis Report: Addendum for Intrinsic Supercriticality Experiments,". Atomics International Technical Data Record NAA-SRMEMO-12614 (November 1967) (80 pages) 
Ki63 T. S. Kirsch, "Specifications for Alloying and Forming SNAP 10A and 2 Fuel Materials," Atomics International Technical Data Record NAA-SR-MEMO-6645, Revised (August 1963) (15 pages)

Kr67 W. E. Krupp, "Post-Irradiation Metallographic Examination of Selected S10FS-3 Reactor Components," Atomics International Technical Data Record NAA-SR-TDR-12390 (March 1967) (10 pages)

Mi65 S. Minor, L. Bixon, and D. Brinkman, "Preliminary Test Results - SNAP 10A FS-3," Atomics International Report NAA-SR-11206 (September. 1965) (44 pages)

Sa63 W. Sawicky, "Fabrication Process Test and Inspection Sheets for SNAP 10A Flight System Cores 3, 4, and 5 Fuel Elements," Atomics International Technical Data Record NAA-SR-MEMO-9367 (November 1963) (46 pages)

Sa64 W. Sawicky, "SNAP 10A FS-1 Core-Fuel Element Data Packages for First Delivery," Atomics Intemational Technical Data Record NAA-SR-MEMO-9855 (April 1964) (414 pages)

Sa64a W. Sawicky, "SNAP 10A FS-1 Core-Fuel Element Data Packages for Second Delivery," Atomics Intemational Technical Data Record NAA-SR-MEMO-9926 (May 1964) (192 pages)

Sa64b W. Sawicky, "SNAP 10A FS-3 Core-Fuel Element Data Packages," Atomics .Intemational Technical Data Record NAA-SR-MEMO-10033 (June 1964) (171 pages)

Sa64c - W. Sawicky, "SNAP 10A FS-4 Core-Fuel Element Data Packages," Atomics Intemational Technical Data Record NAA-SR-MEMO-10208 (July 1964) (171 pages)

Sa64d W. Sawicky, "Addendum to SNAP 10A FS-1, FS-3, and FS-4 Fuel Data Packages for FS-3, FS-4, and FS-5 Systems,"- Atomics Intemational Technical Data Record NAA-SR-MEMO-10815. (December 1964) (84 pages)

St67* D. W. Staub, "SNAP 10A Summary Report," Atomics International Report NAA-SR-12073 (March 1967) (237 pages) 


\begin{tabular}{|c|c|c|c|c|c|c|c|c|c|c|}
\hline \multirow{2}{*}{$\begin{array}{l}\text { Shipping } \\
\text { Document }\end{array}$} & \multirow{2}{*}{$\begin{array}{c}\text { Shipment } \\
\text { Date }\end{array}$} & \multirow{2}{*}{$\begin{array}{c}\text { Al } \\
\text { Can No. }\end{array}$} & \multicolumn{3}{|c|}{ Fuel Identification } & \multicolumn{3}{|c|}{ Fuel Masses (grams) } & \multirow[b]{2}{*}{ Notes } & \multirow{2}{*}{$\begin{array}{c}\text { Prob. INEL } \\
\text { Can No. }\end{array}$} \\
\hline & & & Element & Rod & Location & Unclad & total U. & U-235 & & \\
\hline \multirow[t]{9}{*}{ LAE-JWA-6 } & $5 / 1 / 67$ & 13 & $E-486$ & $668-6$ & 2 & 1355 & 139 & 129 & sectioned & SN-11 \\
\hline & $\cdot$ & & E-150 & $608-6$ & 28 & 1359 & 138 & 129 & & \\
\hline & & & $E-337$ & $659-4$ & 29 & 1356 & 137 & 128 & & \\
\hline & & & E-352 & $664-4$ & 37 & 1354 & 135 & 126 & & \\
\hline & & & $E-350$ & $664-3$ & 30 & 1354 & 135 & 126 & & \\
\hline & & & $E-332$ & $661-5$ & 10 & 1357 & 139 & 129 & see note 1 & \\
\hline & Shipn & tont totals: & 6 & elements & & 8135 & 823 & 767 & & \\
\hline & insfor fuol & late totals: & 6 & elements & & 8135 & 823 & 768 & & \\
\hline & & & & & & & & seo note 2 & & \\
\hline \multirow[t]{8}{*}{ LAE-JWA-7 } & $5 / 3 / 67$ & 16 & $E-439$ & $682-1$ & 33 & 1357. & 138 & 129 & & $\mathrm{SN}-14$ \\
\hline & & & $E-419$ & $677-1$ & 24 & 1357 & 130 & 129 & & \\
\hline & & & $E-390$ & $666-1$ & 25 & 1356 & 138 & 129 & & \\
\hline & & & $E-364$ & $661-2$ & 36 & 1358 & 140 & 130 & & \\
\hline & & & $E-393$ & $663: 5$ & 26 & 1356 & 138 & 129 & . & \\
\hline & & & $E-484$ & $674-2$ & 4 & 1357 & 140 & 130 & & \\
\hline & · Shipn & ent totals: & 6 & elements & & $814 t$ & 833 & 776 & & \\
\hline & insfer fuel & lata totals: & 6 & elements & & 8141 & 833 & 776 & & . \\
\hline \multirow[t]{8}{*}{ LAE-JWA-8 } & $5 / 5 / 67$ & 15 & E-336 & $660-2$ & 18 & 1357. & 138 & 129 & & $\mathrm{SN}-13$ \\
\hline & & & $E-334$ & $659-3$ & 19 & 1356 & 137 & 128 & & \\
\hline & & & $E-456$ & $641-1$ & 11 & 1357 & 140 & 130 & & \\
\hline & & & $E-349$ & $664-2$ & 31 & 1354 & 135 & 126 & & \\
\hline & & & $E-421$ & $678-2$ & 15 & 1357 & 139 & 129 & see note 3 & \\
\hline & & & $E-345$ & $658-5$ & 20 & 1356 & 137 & 128 & & . \\
\hline & shipn & ent totals: & 6 & elements & & 8137 & 826 & 770 & & \\
\hline & insfer fuel & lata totals: & 6 & elements & & 8137 & 826 & 770 & & \\
\hline \multirow[t]{6}{*}{ LAE-JWA-9. } & $5 / 9 / 67$ & $\cdot 14$ & $E-338$ & $659-5$ & 32 & 1355 & 137 & 128 & see note 4 & $\mathrm{SN}-12$ \\
\hline & & & $E-365$ & $661-1$ & 14. & 1358 & 140 & 130 & & \\
\hline & & & $E-136$ & $615-5$ & 21 & 1357 & 136 & 127 & see note 5 & \\
\hline & & & $E-348$ & - $659-2$ & 35 & 1355. & 137 & 128 & & \\
\hline & & & $E-333$ & $661-6$ & 22 & 1358 & 140 & 130 & & \\
\hline & & & $E-479$ & $673-2$ & 23 & 1355 & 130 & 129 & & \\
\hline & Shipn & ent totals: & 6 & elements & & 8138 & 829 & 772 & & \\
\hline & insfer fuel & lata totals: & 6 & elements & & 8138 & 829 & 772 & & \\
\hline \multirow[t]{6}{*}{ :AE-JWA-10 } & $5 / 11 / 67$ & 17 & $E-441$ & $682-4$ & 16 & 1357 & .138 & 129 & . & SN-15 \\
\hline & & & $E-440$ & $682-2$ & 6 & 1357 & 138 & 129 & & \\
\hline & & & $E-528$ & $595-5$ & 5 & 1364 & 137 & 128 & & \\
\hline & & & $E-435$ & $678-6$ & 12 & 1357 & 139 & 129 & & \\
\hline & & & $E-190$ & $613-4$ & 27 & 1358 & 137 & 128 & & \\
\hline & & & $E-442$ & $683-6$ & 34 & 1357 & 139 & 129 & see note 6 & \\
\hline \multirow{2}{*}{ r } & Shipn & ent totals: & 6 & elements & & 8150 & 828 & 772 & & \\
\hline & insfer fuel & lata totals: & 6 & elements & & 8150 & 828 & 772 & & \\
\hline
\end{tabular}




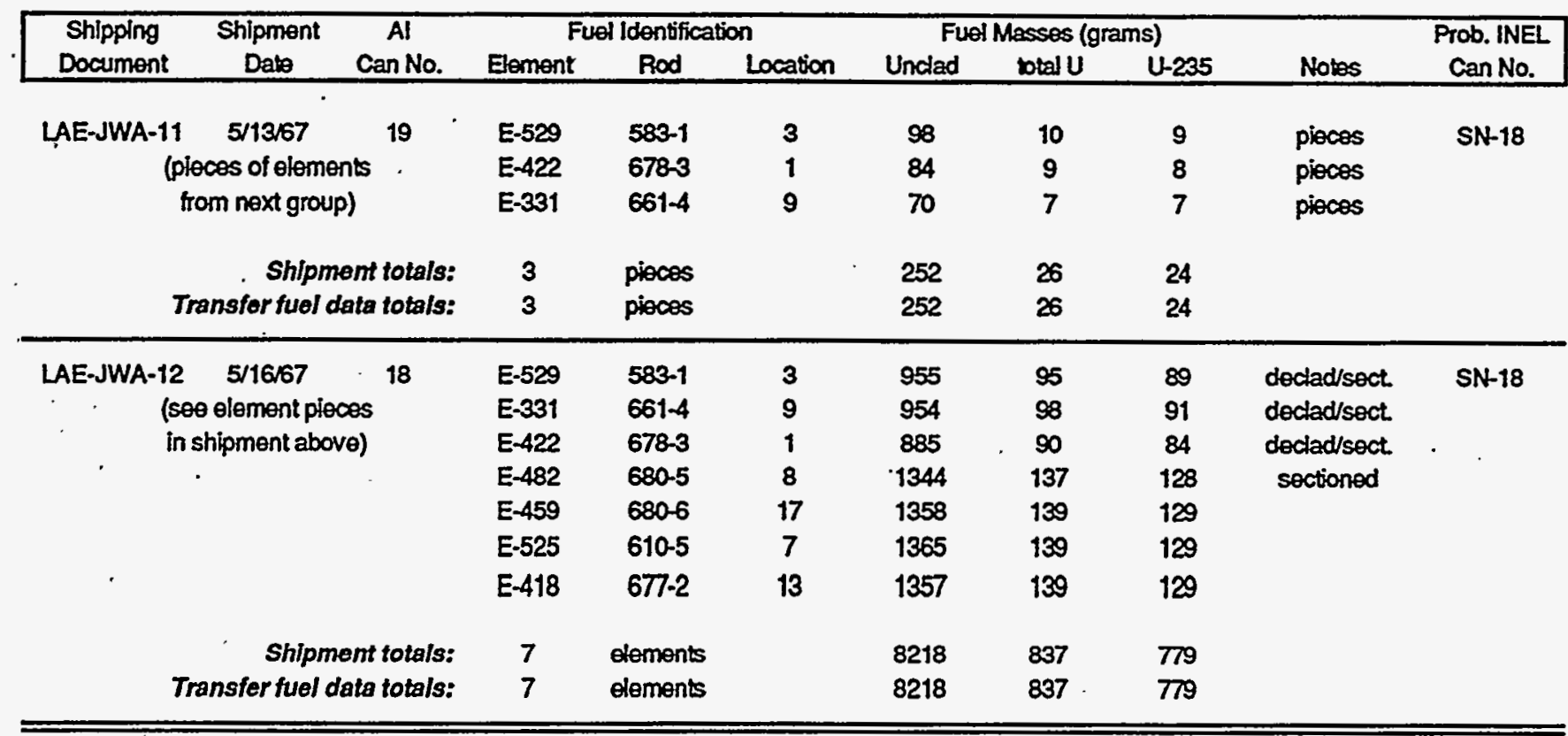

10FS-3 reactor totals:

Transfor fuel data totals:

37
$\quad 37$. elements
.$\quad$ elements

49171

49171
5002

5002
4660

4661

see note 2

References: Data transcribed from archived copies of original shipping records

Mass totals and element IDs compared with 10FS-3 fuel data summary shipping sheet

Fuel element identifications correlated with post-iradiation examination document Go67a (NAA-SR-MEMO-12338) and final (addendum) data package Sa64d (NAA-SR-MEMO-10815); note post-irradiation reports provide best identification of in-core elements because of redistribution between $10 A$ cores after first FS- 1 tests.

Fuel rod identifications from QA data packages Sa64 (E-100's), Sa64a (E-300's and 400's), and Sa64d (E-500's)..

Notes:

1. Shipping document incorrectly identifies as E-322; in-core elements identified by cross-comparison with Go67a

2: For Al Can No. 3, 1-g discrepancy between U-235 mass sum and fuel data summary sheet entry not resolved

3. Shipping document incorrecty identifies as E-42; in-core elements identified by cross-comparison with G067a

4. Shipping document incorrectly identifies as E-388; in-core elements identified by cross-comparison with Go67a

5. Shipping document incorrectly identifies as E-316; in-core elements identified by cross-comparison with 5067 a

6. Shipping document incorrecty identifies as E-440; in-core elements identified by cross-comparison with G067a

10FS-3 Fuel Data transfer summary sheet has two additional typos: Total material available incluces 33 (not 34) complete elements Element list for ID \#18 should list E529 instead of E524 


\section{SNAP-8 EXPERIMENTAL REACTOR (S8ER)}

Date went critical:

Initiation of testing:

Date of shutdown:

Thermal power:

Thermal energy:

Time at power and temperature:

Operating location:

\author{
May 1963 (Di67) \\ November 22, 1963 (O167) \\ April 15, 1965 (0167) \\ $600 \mathrm{kWt}$ (Di67) \\ $5.1 \times 10^{6} \mathrm{kWt}-\mathrm{h}$ (Sw69, Di67) \\ $365 \mathrm{~d}>400 \mathrm{kWt} \& 100 \mathrm{~d}$ at $600 \mathrm{kWt}$, at $1300^{\circ} \mathrm{F}$ (Di67) \\ SSFL Building 010
}

\subsection{S8ER GENERAL DESCRIPTION}

The SNAP-8 reactor program represented an extension of zirconium hydride technology from the 50-kWt, $1200^{\circ} \mathrm{F}$, one-year life design of the SNAP-2 reactor to a $600-\mathrm{kWt}, 1300^{\circ}, 10,000$-hour life reactor. [Di67] In order to achieve the higher power and temperature, the core size was increased and the fuel diameter reduced: The S8ER reactor consisted of a homogeneously combined fuel and moderator (a hydrided zirconium-uranium alloy) with movable beryllium reflectors for control and liquid $\mathrm{NaK}$ as the heat transfer . medium. The subsystem was a direct extension of the technology developed and tested for the lower powered SNAP-2 reactors. The reactor contained 211 fuel-moderator elements arranged in a triangular pattern on $14.5-\mathrm{mm}(0.57$-in.) centers. The assembly resulted in a hexagonal right cylinder, with slightly chopped.comers, $20.3 \mathrm{~cm}(8 \mathrm{in}$.) across flats and $36.75 \mathrm{~cm}$ (14.47 in.) long.

Each fuel element consisted of an individual fuel rod, a hydrogen diffusion barrier containing burnable poison, exterior cladding, end caps, and grid plate indexing pins. The rods were.composed of enriched $\left(93.15 \%{ }^{235} \mathrm{U}\right)$ fuel- and hydrogen moderator in the form of a solid zirconium-uranium alloy (10\% uranium) hydrided to a hydrogen density of $6 \times 10^{22}$ atoms $/ \mathrm{cm}^{3}$.. The rods were $13.5 \mathrm{~mm}(0.532 \mathrm{in}$.) in diameter and $0.356 \mathrm{~m}$ (14 in:) long. The hydrogen diffusion barrier was a $0.0776-\mathrm{mm}-(0.003$-in.-) thick ceramic coating applied on the inside surface of the cladding to prevent the loss of the hydrogen moderator. $\mathrm{A} \mathrm{Sm}_{2} \mathrm{O}_{3}$ burnable poison $(1.3 \mathrm{mg} / \mathrm{cm})$ was added to the ceramic coating to compensate for the reactivity loss caused by the buildup of fission-product poison. The cladding consisted of 13.7-mn(0.43-in.-) ID Hastelloy $N$ (a nickel-base alloy) tubing with a $0.25-\mathrm{mm}(0.01-i n$ ) wall thickness. The cladding envelope was completed by Hastelloy $\mathrm{N}$ end caps seal-welded to the tubing. The manufacturing process ensured that a continuous diffusion barrier was provided on the inside surface of the cladding. The finished fuel element was $14.2 \mathrm{~mm}$ (0.56 in.) in diameter and $0.368 \mathrm{~m}$ (14.47 in.) long (excluding the positioning pins located at the ends of each element).

Post-test examination of the S8ER revealed that $79 \%$ of the 211 fuel elements had cladding cracks, even though the reactor had met or exceeded all test objectives. Detailed examination of selected fuel elements . indicated that the cracks resulted primarily from over-temperature swelling of the UZrH fuel, coupled with the low irradiated ductility of the Hastelloy $\mathrm{N}$ alloy cladding material.

General descriptions of the S8ER are given in references Di67, AN76, and An83, the latter including a design data summary table and schematic drawing. Schematic drawings are also given in Mi66. 


\subsection{S8ER REACTOR AND FUEL IDENTIFICATION}

Reactor: $\quad$ SNAP-8 Experimental Reactor (S8ER)

Core fuel Identification: S8ER (same as reactor name)

Reactor designer, builder, operator: Atomics Intemational

- Reactor owner: Atomic Energy Commission (now DOE)

Fuel designer, builder: Atomics International

Fuel owner: Atomic Energy Commission (now DOE)

\subsection{S8ER DESIGN REACTOR PHYSICS AND CORE DESCRIPTION}

Fuel elements/assemblies: 211

Hu64 211 fuel elements were in the core; 215 fuel elements were delivered

Design neutron flux:

Design neutron energy: Mean neutron fission energy near 0.26. eV (Sw69)

Core map and element locator:

O167 Core maps showing location of elements selected for detailed post-irradiation examination .

An original (legible) vellum of the core loading was located in a.separate source data file

\subsection{S8ER FUEL FABRICATION INFORMATION}

Fuel specifications and drawings:

Ca63 Page 4 tabulates the fuel element engineering design drawings

Hu64 Table 1 abstracts fuel element specification requirements

(most drawings and specs available through Rocketdyne Advanced Power Systems Technical Data)

Drawing 7570-18011 "Fuel Element Ass'y" (04/62)

Drawing 7570-18010 "Fuel Rod" (02/62)

Fuel fabrication and quality control:

Ca63 Manufacturing planning document: fabrication process flow sheet forms (Manufacturing Travelers). Completed flow sheets are not available.

Na62 Compilation of original certified inspection and test reports for fuel elements delivered for the S8ER core (2is elements delivered for the 211-element core). Contains dimensional, chemical, and hydrogen leak data; non-conformance information, manufacturing traceability, and nondestructive test results for all components of each fuel element. This includes cladding (end caps, coating, tubing) and fuel material.

Na63 Quality control program flow sheet forms used for fabrication of the S8ER fuel elements. The body of this report lists all engineering drawings and specifications used for the fuel element fabrication.

Hu64 Fuel alloy impurities

Ca64 Overall summary of S8ER fuel fabrication (including photographs of equipment and parts) 
Fuel cladding, inner coatings, and other non-fuel materials:

$\mathrm{Na63}$ Includes quality control for fuel cladding, etc. as well as fuel rods.

Hu64 Description of fuel element cladding, coating (AI 8763D), end caps. Properties of cladding raw materials.

Bu64 Qualitative composition of AI 8763D ceramic coating

Potential fuel chemical reactions:

Potential RCRA-regulated materials:

Quantities of materials:

See shipping spreadsheets (fuel rods, $U,{ }^{235} \mathrm{U}$ )

Hu64 Extended table correlates fuel element serial number with fuel rod serial number. Provides net weights, hydrogen leak rates, dimensions, uranium enrichment, carbon and hydrogen concentrations, etc.

Fuel assembly identification methods:

Fuel element and rod identification marking methods and locations are given on the engineering design drawings.

\subsection{S8ER OPERATIONAL HISTORY}

Core Operating History:

O167. Testing occurred from November 22; 1963 to. April 15, 1965, for a total of 12,000 hours,

with $5 \times 10^{6} \mathrm{kWh}$ energy release, of which 6760 hours were between 400 and $600 \mathrm{kWt}$.

Ol67 S8ER operating history timeline (Fig. 1)

Core neutron flux profile:

Operation abnormalities:

O167 As of April 28, 1964, there were 37 reactor scrams. The scrams were associated with test support equipment and instrumentation not intended for use in an actual flight system.

Core shut-down date:

O167 April 15, 1965

Core discharge date:

Mi66 S8ER cask received at AI Hot Laboratory for post-irradiation examination July 28, 1965

\subsection{S8ER POST-IRRADIATION PROPERTIES AND EXAMINATION}

Pe66 S8ER fuel element post-irradiation evaluation review of the entire test program

\section{Visual observations:}

Mi66 Highly detailed screening examination data for all 211 core fuel elements, including visual, macro photographic, gamma scanning, mass, and some dimensional data

Mi66a Comprehensive detailed examination data for selected S8ER fuel elements and fuel material. Includes fuel element and fuel material weights, length and diameter measurements, gamma scans, longitudinal distortion, hydrogen leak testing, density measurements (fuel material), fission gas analyses, burnup analyses, fuel metallography for microstructure, coating adherence testing, cladding tensile testing and metallography 
Mi66b Summary of AI66a book volume vs. core location for Kollmorgan and stereo photographs

AI66a Complete set of Kollmorgan and stereo examination photographs (over 2000) taken of all of the core elements

Al66b Source screening examination stereo data sheets for all fuel elements

0167 Summarizes, and provides analysis of, highly detailed information provided in Mi66 and Mi66a. Table 1 summarizes fuel element cracks by ring number (167 of 211 elements, 79\%) had observable cracks. Locations summarized in core layout drawing in Fig. 5. The text provides an analysis of all of the data with extensive photomicrographs, visual observations, detailed data measurements, and methods of inspection and testing. Appendix I includes selected fabrication data. Appendix II contains photographs of the condition of every fuel element examined. Data summaries, including photomicrographs of all elements examined, are given in Appendix III; these data include diameter changes, density, hydrogen content, sample locations for burnup analysis etc., and relative gamma activity plots.

Dimensions:

Mi66 Some dimensional data

AI66c Source screening examination length measurement data sheets for all fuel elements

$\therefore \quad$ Al66e Source screening examination diameter measurement data sheets for all fuel elements

Mi66a Detailed dimensional data on selected de-clad fuel material

O167 Post-irradiation dimensional analyses

AI65 Source data sheets of fuel element post-irradiation dry weights

\section{Metallurgical states of materials:}

Le66 . Studies of dehyriding and rehydriding of unirradiated fuel to provide. a baseline for

$\therefore \quad$ irradiated fuel studies (may be useful- if it becomes necessary to dehydride the SNAP fuels)

- Mi66a Fuel metallography for microstructure; includes color photomicrographs

Mi67. Photomicrographs and analysis of metallurgical structure shown

Ol67 .Detailed photomicrographs

Cladding defects:

Mi66a Cladding tensile testing; cladding metallography

O167 Detailed examination of cladding cracks

Corrosion or chemical contamination:

: Mi66a Coating adherence testing (to cladding)

O167. Ceramic coating adhesion to fuel rods, including contamination information (Table 5)

Hydrogen effects:

AI66 $i$ Source screening examination hydrogen analysis data sheets for all fuel elements

Mi66a Hydrogen leak testing and hydrogen analysis of fuel rod samples

0167 Average hydrogen loss (Table 11)

Burnup:

Mi66a Burnup analyses for selected elements (24 samples from 8 rods). Ranges from 0.04 to 0.22 metal-atom \% by mass spectrometer analysis at INEL, and 0.099 to 0.234 metal-atom $\%$ by radiochemical analysis.

0167 Burnup analyses (Table 10 and Fig. 50) 


\section{Fission products:}

Mi66a Fission gas analysis

O167 Fission product release fractions (Table 16), based on samples of the NaK coolant during three periods of S8ER operation

Mi66a Gamma scans across fuel elements of ${ }^{95} \mathrm{Zr}$ photopeak

AI66d Source screening examination gamma scanning data sheets for all fuel elements

\section{Transuranics:}

(can be calculated from available reactor information)

Activation products:

Decay heat generation:

Radiation level decay curves:

Alpha contamination:

(not relevant for the declad fuels)

\subsection{S8ER ON-SITE STORAGE HISTORY}

Post-irradiation examinations took place in the AI Hot Laboratory (AIHL) following reactor shut-down. Reactor power test operations terminated on April 15, 1965 and the S8ER cask was received at the AIHL on July 28, 1965 (Mi66). The only fuel disassembly that took place was for hot cell examination, which is covered in the post-irradiation examination section. SNAP fuel elements were subsequently stored in air at the RMDF in dry storage vaults in preparation for shipment to INEL. There were no wet-storage facilities available at Atomics International. . No detailed storage history documentation is available.

\section{8 - S8ER SHIPPING RECORDS}

The shipping records for the S8ER fuel shipments to INEL were reviewed in detail. The original records are difficult to read, and were transcribed onto the S8ER spreadsheet that is reproduced at the end of this section. The spreadsheet lists the core location, fuel rod identification, unclad fuel rod mass, total uranium mass, and ${ }^{235} U$ mass for each fuel element, plus the shipping document number, shipment date, Atomics Intermational can number, and probable INEL aluminum can number. The latter is base on document copies received from INEL as part of the current review activity. A total of 211 irradiated S8ER fuel elements were shipped to INEL.

The fuel element and fuel rod identifications were compared with QA document Hu64. Transcription errors were found for two fuel element numbers in the shipping documents and are noted in the spreadsheet. Fuel element locations in the core were obtained from 0167 and an original velum of the core loading found in archived Atomics International Hot Laboratory files. The mass totals shown on the spreadsheet were calculated from the individual recorded fuel element data. No summary fuel data sheet is available for mass sum comparisons.

\subsection{S8ER REFERENCES}

AI65 Atomics Intemational, "S8ER Screening Examination Dry-Weight Data Sheets in Sequence from Ring I to Ring IX," Atomics Intemational binder of source data sheets 
AI66a Atomics International Hot Laboratory Staff, "[S8ER] Post Irradiation Screening Examination :Photographs," Atomics International Technical Data Records NAA-SR-MEMO-12011, Volumes I to XIV (1966) (volumes not labeled with NAA number)

AI66b Atomics International Hot Laboratory Staff, "S8ER Screening Examination Stereo Data Sheets in" Sequence from Ring I to Ring IX," Atomics International source data book (1966)

AI66c Atomics Intemational Hot Laboratory Staff, "S8ER Screening Examination Length Measurement Data Sheet in Sequence from Ring I to Ring IX," Atomics Intemational source data book (1966)

AI66d Atomics International Hot:Laboratory Staff, "S8ER Screening Examination Gamma Scanning Data Sheets in Sequence from Ring I to Ring IV, from Ring V to Ring VII, and from Ring VIII to Ring IX," Atomics International source data books, 3 volumes (1966)

AI66e Atomics International Hot Laboratory Staff, "S8ER Screening Examination Diameter Measurements Data Sheets in Sequence from Ring I to Ring V, and from Ring VI to Ring IX,". Atomics Intemational source data books, 2 volumes (1966)

Al66f Atomics Intemational Hot Laboratory Staff, "S8ER Screening Examination Hydrogen Analysis Data Sheets in Sequence from Ring I to Ring IX," Atomics International source data book (1966)

AN76 Anonymous, "Zirconium Hydride (SNAP) Reactor Space Power Programs. Summary of Major Activities and Accomplishments," · Rockwell 'International Energy Systems Group (June 1976)

An83 R. V. Andersón, et al., "Space Reactor Electric Systems. Subsystem Technology Assessment," Rockwell International Energy Systems Group Report ESG-DOE-13398 (March 1983).

Bu64 G. F. Burdi, Ed., "SNAP Technology Handbook. Volume II. Hybrid Fuels and Claddings," . Atomics International Report NAA-SR-8617, Volume II (November 1964) (129. pages)

Ca63 D. C. Campbell, et al., "SNAP 8ER Fabrication Process Sheets and Auxiliary. Forms," Atomics International Technical Data Record NAA-SR-MEMO-8273 (February 1963) (41 pages)

Ca64 D. C. Campbell, et al., "SNAP 8 Experimental Reactor Fabrication and Engineering," Atomics Intemational Report NAA-SR-8430 (March 1964) (55 pages)

Di67 H. M. Dieckamp, "Nuclear Space Power Systems,". Atomics International (September .1967) (unpublished book, 388 pages)

Hu64 H. J. Hubbell and W. E. Nagel, "SNAP 8 Experimental Reactor Fuel Element Acceptance Testing," Atomics International Report NAA-SR-8589 (March 1964) (63 pages)

Le66 S. K. Lee, "A Study of Dehydriding of S8ER Fuel," Atomics International Technical Data Record NAA-SR-MEMO-12197 (October 1966) (20 pages)

Mi66 K. J. Miller, "Post-Irradiation Screening Examination of the S8ER Fuel Elements," Atomics Intemational Technical-Data Record NAA-SR-MEMO-11880 (March 1966) (299 pages)

Mi66a K. J. Miller, "Post-Irradiation Detailed Examination of Selected S8ER Fuel Elements," Atomics Intemational Technical Data Record NAA-SR-MEMO-12165 (1966) (color copy, 304 pages) 
Mi66b K. J. Miller, "S8ER Screening Examination Photograph Books," Atomics International Internal. Letter to G. W. Meyers dated 17 June 1966

Mi67 K. J. Miller, "Electron Microscopy Analysis of Irradiated S8ER and NAA 115-1 Fuel," Atomics Intemational Technical Data Record NAA-SR-MEMO-12368 (March 1967) (51 pages)

Na62 W. E. Nagel, "S8ER Fuel Element Data Package," Atomics International Technical Data Record NAA-SR-MEMO-7623 (October 1962) (1078 pages)

Na63 W. E. Nagel, "S8ER Fuel Element Quality Control - Upgrading Point Tests and Inspections," Atomics International Technical Data Record NAA-SR-8283 (February 1963) (44 pages)

O167* P. S. Olson, K. J. Miller, and E. J. Donovan, "Postoperation Evaluation of Fuel Elements from the SNAP 8 Experimental Reactor," Atomics Intemational Report NAA-SR-12029 (September 1967) (223 pages)

Pe66. H. Pearlman, et al., "SNAP 8 Experimental Reactor Fuel Element Behavior: Atomics International Task Force Review," Atomics International Report NAA-SR-MEMO-12210 (November 1966)

Sw69* L. D. Swenson, "SNAP 8 Development Reactor Nuclear Analysis," Atomics International Report AI-AEC-12864 (October 1969) (75 pages) 


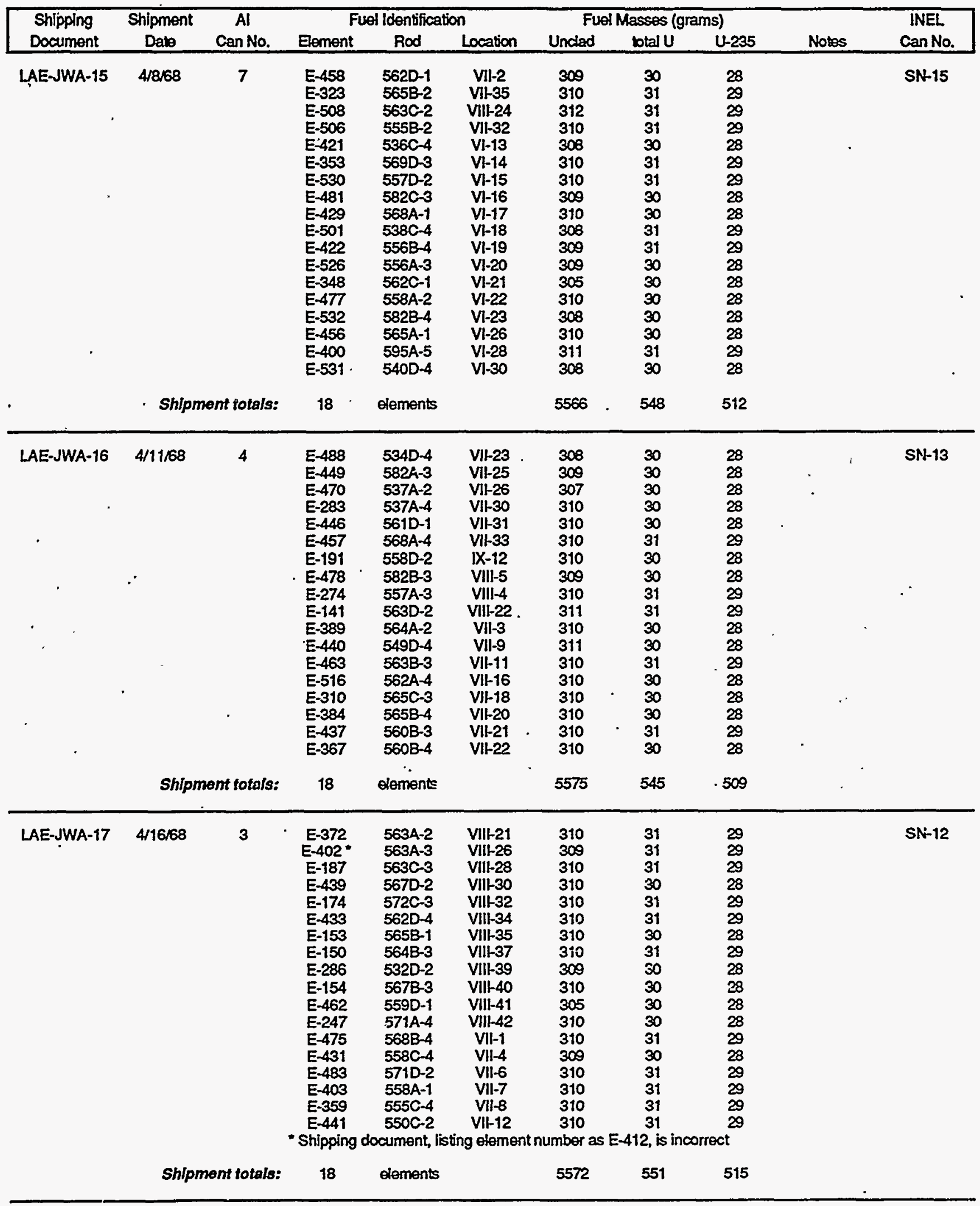




\begin{tabular}{|c|c|c|c|c|c|c|c|c|c|c|}
\hline \multirow{2}{*}{$\begin{array}{l}\text { Shipping } \\
\text { Document }\end{array}$} & \multirow{2}{*}{$\begin{array}{c}\text { Shipment } \\
\text { Date }\end{array}$} & \multirow{2}{*}{$\begin{array}{c}\text { Al } \\
\text { Can No. }\end{array}$} & \multicolumn{3}{|c|}{ Fuel Identification } & \multicolumn{3}{|c|}{ Fuel Masses (grams) } & \multirow[b]{2}{*}{ Notes } & \multirow{2}{*}{$\begin{array}{c}\text { INEL } \\
\text { Can No. }\end{array}$} \\
\hline & & & Element & Rod & Location & Unclad & total U & U-235 & & \\
\hline \multirow[t]{2}{*}{ LAE-JWA-18 } & $4 / 18 / 68$ & $11 A$ & $\begin{array}{l}E-412 \\
E-415 \\
E-430 \\
E-397 \\
E-479 \\
E-451 \\
E-272 \\
E-452 \\
E-453 . \\
E-411 \\
E-428 \\
E-499 \\
E-417 \\
E-322 \\
E-529 \\
E-445 \\
E-360 \\
E-349\end{array}$ & $\begin{array}{r}558 D-3 \\
562 C-4 \\
562 D-2 \\
549 D-2 \\
559 C-2 \\
568 B-3 \\
561 C-4 \\
571 A-2 \\
582 B-1 \\
557 B-1 \\
567 C-1 \\
556 C-3 \\
562 A-1 \\
555 D-2 \\
570 D-2 \\
549 C-2 \\
582 B-2 \\
570 A-2\end{array}$ & $\begin{array}{c}\text { VIII-8 } \\
\text { VIlI-9 } \\
\text { VIII-12 } \\
\text { VIII-13 } \\
\text { VII-14 } \\
\text { VII-15 } \\
\text { VII-16 } \\
\text { VIII-17 } \\
\text { Vill-19 } \\
\text { VIII-20 } \\
\text { V-16 } \\
\text { V-17 } \\
\text { V-20 } \\
\text { VII-7 } \\
I V-8 \\
\text { VI-9 } \\
\text { VI-14 } \\
\text { VI-11 }\end{array}$ & $\begin{array}{l}311 \\
310 \\
310 \\
310 \\
310 \\
309 \\
311 \\
310 \\
308 \\
309 \\
310 \\
309 \\
310 \\
310 \\
310 \\
309 \\
300 \\
310\end{array}$ & $\begin{array}{l}31 \\
31 \\
30 \\
31 \\
30 \\
31 \\
31 \\
31 \\
30 \\
30 \\
30 \\
31 \\
31 \\
31 \\
31 \\
31 . \\
30 \\
31\end{array}$ & $\begin{array}{l}29 \\
29 \\
28 \\
29 \\
28 \\
29 \\
29 \\
29 \\
28 \\
28 \\
28 \\
29 \\
29 \\
29 \\
29 \\
29 \\
28 \\
29\end{array}$ & & SN-17 \\
\hline & \multicolumn{2}{|c|}{ Shlpment totals: } & 18 & otements & & $\mathbf{5 5 7 5}$ & 552 & 516 & & \\
\hline \multirow[t]{2}{*}{ LAE-JWA-19 } & $4 / 2368$ & 6 & $\begin{array}{c}E-503 \\
E-192 \\
E-419 \\
E-484 \\
E-454 \\
E-413 \\
\text { E-523 } \\
\text { E-504 } \\
\text { E-466 } \\
\text { E-343 } \\
\text { E-513 } \\
\text { E-505 } \\
\text { E-177 } \\
\text { E-369 } \\
\text { E-536* } \\
\text { E-357 } \\
\text { E-517 } \\
\text { E-448 } \\
\text { Shipping }\end{array}$ & $\begin{array}{c}556-\mathrm{D} 1 \\
557-\mathrm{C} 3 \\
549-\mathrm{C} 1 \\
570-\mathrm{D} 1 \\
567-\mathrm{A} 3 \\
567-\mathrm{B} 1 \\
555-\mathrm{A} 2 \\
561-\mathrm{C} 1 \\
567-\mathrm{C} 3 \\
555-\mathrm{D} 3 \\
582-\mathrm{C4} \\
555-\mathrm{A4} \\
558-\mathrm{A4} \\
561-\mathrm{A4} \\
557-\mathrm{A} 1 \\
555-\mathrm{A} 1 \\
559-\mathrm{B4} \\
549-\mathrm{D} 3 \\
\text { locument af }\end{array}$ & $\begin{array}{l}I X-2 \\
\mid X-37 \\
\text { VII-5 } \\
\text { VII-10 } \\
\text { VII-13 } \\
\text { VIII-31 } \\
\text { VII-15 } \\
\text { VII-24 } \\
\text { VII-34 } \\
\text { VI-1 } \\
\text { VI-2 } \\
\text { VI-4 } \\
\text { Vl-5 } \\
\text { VI-6 } \\
\text { VI-7 } \\
\text { VI-8 } \\
\text { VI-10 } \\
\text { VI-12 } \\
\text { ears to list }\end{array}$ & $\begin{array}{c}305 \\
310 \\
310 \\
310 \\
310 \\
310 \\
310 \\
312 \\
310 \\
310 \\
302 \\
310 \\
310 \\
310 \\
310 \\
310 \\
311 \\
311 \\
E-536 ;\end{array}$ & $\begin{array}{l}30 \\
31 \\
31 \\
31 \\
31 \\
30 \\
30 \\
31 \\
30 \\
31 \\
31 \\
31 \\
31 \\
31 \\
30 \\
31 \\
31 \\
30 \\
\text { Id be E }\end{array}$ & $\begin{array}{l}28 \\
29 \\
29 \\
29 \\
29 \\
28 \\
28 \\
29 \\
28 \\
29 \\
29 \\
29 \\
29 \\
29 \\
28 \\
29 \\
29 \\
28\end{array}$ & \multirow[t]{2}{*}{$\cdot$} & $\mathrm{SN}-14$ \\
\hline & \multicolumn{2}{|c|}{ Shlpment totals: } & 18 & elements & & 5571. & 552 & 516 & & \\
\hline \multirow[t]{2}{*}{ LAE-JWA-20 } & $4 / 25 / 68$ & 1 & $\begin{array}{l}E-249 \\
E-212 \\
E-471 \\
E-281 \\
E-146 \\
E-164 \\
E-149 \\
E-245 \\
E-237 \\
E-383 \\
E-291 \\
E-137 \\
E-292 \\
E-280 \\
E-311 \\
E-313 \\
E-350 \\
E-424\end{array}$ & $\begin{array}{l}568 \mathrm{C}-2 \\
535 \mathrm{~A}-1 \\
556 \mathrm{D}-3 \\
530 \mathrm{D}-1 \\
570 \mathrm{~A}-3 \\
569 \mathrm{~B}-3 \\
570 \mathrm{~B}-2 \\
558 \mathrm{D}-4 \\
570 \mathrm{~B}-1 \\
571 \mathrm{~A}-3 \\
555 \mathrm{C}-2 \\
569 \mathrm{~B}-4 \\
568 \mathrm{D}-2 \\
556 \mathrm{~A}-4 \\
564 \mathrm{~B}-2 \\
550 \mathrm{D}-1 \\
561 \mathrm{C}-3 \\
567 \mathrm{~A}-2\end{array}$ & $\begin{array}{l}\mid X-8 \\
\mid X-13 \\
\mid X-16 \\
1 X-18 \\
\mid X-19 \\
\mid X-20 \\
1 X-26 \\
\mid X-27 \\
\mid X-32 \\
\mid X-35 \\
\mid X-40 \\
\mid X-43 \\
\mid X-44 \\
\mid X-45 \\
\mid X-46 \\
\mid X-47 \\
\text { VIII-1 } \\
\text { V|II-3 }\end{array}$ & $\begin{array}{l}310 \\
308 \\
310 \\
308 \\
310 \\
308 \\
310 \\
310 \\
309 \\
310 \\
310 \\
309 \\
305 \\
309 \\
310 \\
306 \\
311 \\
310\end{array}$ & $\begin{array}{l}30 \\
30 \\
31 \\
30 \\
30 \\
31 \\
31 \\
30 \\
30 \\
30 \\
31 \\
30 \\
31 \\
30 \\
31 \\
31 \\
31 \\
31\end{array}$ & $\begin{array}{l}28 \\
28 \\
29 \\
28 \\
28 \\
29 \\
29 \\
28 \\
28 \\
28 \\
29 \\
28 \\
29 \\
28 \\
29 \\
29 \\
29 \\
29\end{array}$ & & SN-11 \\
\hline & Shlpn & ent totals: & 18 & glements & & 5563 & 549 & 513 & & \\
\hline
\end{tabular}




\begin{tabular}{|c|c|c|c|c|c|c|c|c|c|c|}
\hline \multirow{2}{*}{$\begin{array}{l}\text { Shipping } \\
\text { Document . }\end{array}$} & \multirow{2}{*}{$\begin{array}{c}\text { Shipment } \\
\text { Date }\end{array}$} & \multirow{2}{*}{$\begin{array}{c}\text { Al } \\
\text { Can No. }\end{array}$} & \multicolumn{3}{|c|}{ Fuel Identification } & \multicolumn{3}{|c|}{ Fud Masses (grams) } & \multirow[b]{2}{*}{ Nans } & \multirow{2}{*}{$\begin{array}{c}\text { INEL } \\
\text { Can No. }\end{array}$} \\
\hline & & & Element & $\operatorname{Rod}$ & Location & Unclad & bolal U & $u-235$ & & \\
\hline \multirow[t]{2}{*}{ LAE-JWA-21 } & $5 / 6 / 68$ & 8 & $\begin{array}{l}E-330 \\
E-289 \\
E-315 \\
E-201 \\
E-443 \\
E-482 \\
E-361 \\
E-370 \\
E-518 \\
E-487 \\
E-472 \\
E-496 \\
E-461 \\
E-489 \\
E-427 \\
E-434 \\
E-392 \\
E-509\end{array}$ & $\begin{array}{l}555 B-4 \\
570 A-4 \\
560 C-1 \\
569 D-2 \\
530 A-1 \\
560 C-4 \\
571 B-2 \\
557 D-1 \\
572 A-2 \\
582 A-2 \\
561 C-2 \\
532 C-2 \\
560 B-2 \\
568 C-1 \\
568 A-3 \\
550 D-3 \\
559 A-3 \\
564 A-1\end{array}$ & $\begin{array}{l}V-1 \\
V-2 \\
V-3 \\
V-4 \\
V-6 \\
V-7 \\
V-8 \\
V-9 \\
V-11 \\
V-12 \\
V-13 \\
V-14 \\
V-15 \\
v-18 \\
V-19 \\
V-22 \\
V-23 \\
V-24\end{array}$ & $\begin{array}{l}310 \\
310 \\
310 \\
310 \\
307 \\
310 \\
310 \\
309 \\
310 \\
309 \\
310 \\
308 \\
310 \\
310 \\
310 \\
310 \\
310 \\
310\end{array}$ & $\begin{array}{l}31 \\
31 \\
30 \\
31 \\
31 \\
31 \\
31 \\
30 \\
31 \\
30 \\
31 \\
31 \\
30 \\
30 \\
31 \\
30 \\
31 \\
31\end{array}$ & $\begin{array}{l}29 \\
29 \\
28 \\
20 \\
29 \\
29 \\
29 \\
28 \\
29 \\
28 \\
29 \\
29 \\
28 \\
28 \\
29 \\
28 \\
29 \\
29\end{array}$ & & $\mathrm{SN}-16$ \\
\hline & \multicolumn{2}{|c|}{ Shipment totals: } & 18 & elements & & 5573 & 552 & 516 & & . \\
\hline \multirow[t]{2}{*}{ LAE-JWA-22 } & $5 / 8 / 68$ & 9 & $\begin{array}{l}E-420 \\
E-319 \\
E-423 \\
E-490 \\
E-308 \\
E-271 \\
E-303 \\
E-522 \\
E-408 \\
E-155 \\
E-278 \\
E-335 \\
E-352 \\
E-416 \\
E-521 \\
E-425 \\
E-500 \\
E-511\end{array}$ & $\begin{array}{l}558 C-3 \\
555 C-3 \\
572 D-1 \\
572 B-1 \\
557 D-4 \\
559 C-4 \\
565 A-4 \\
568 A-2 \\
557 C-4 \\
569 C-4 \\
565 A-2 \\
559 A-2 \\
569 D-4 \\
555 D-1 \\
567 D-3 \\
571 D-3 \\
557 B-5 \\
571 D-1\end{array}$ & $\begin{array}{c}\mid X-4 \\
\mid X-21 \\
\text { VIII-11 } \\
\text { VII-27 } \\
\text { IV-2 } \\
\text { IV-3 } \\
\text { IV-4 } \\
\text { IV-5 } \\
\text { IV-6 } \\
\text { IV-7 } \\
\text { IV-9 } \\
\text { IV-10 } \\
\text { IV-11 } \\
\text { IV-14 } \\
\text { N-15 } \\
\text { IV-16 } \\
\text { IV-17 } \\
\text { IV-18 }\end{array}$ & $\begin{array}{l}310 \\
310 \\
310 \\
310 \\
310 \\
305 \\
303 \\
310 \\
310 \\
310 \\
310 \\
310 \\
310 \\
309 \\
310 \\
310 \\
307 \\
309\end{array}$ & $\begin{array}{l}30 \\
31 \\
31 . \\
30 \\
31 \\
31 \\
30 \\
30 \\
30 \\
31 \\
31 \\
31 \\
30 \\
30 \\
30 \\
30 \\
30 \\
31\end{array}$ & $\begin{array}{l}28 \\
29 \\
29 \\
28 \\
29 \\
29 \\
28 \\
28 \\
28 \\
29 \\
29 \\
29 \\
28 \\
28 \\
28 \\
28 \\
28 \\
29\end{array}$ & & SN-16 \\
\hline & \multicolumn{2}{|c|}{ Shlpment totals: } & 18 & dements & & 5563 & 548 & 512 & & \\
\hline LAE-JWA-23 & $7 / 29 / 68$ & 10 & $\begin{array}{l}E-464 \\
E-231 \\
E-485 \\
E-520 \\
E-447 \\
E-394 \\
E-442 \\
E-347 \\
E-436 \\
E-337 \\
E-426 \\
E-493 \\
E-524 \\
E-329 \\
E-287 \\
E-346 \\
E-379 \\
E-514\end{array}$ & $\begin{array}{l}569 C-1 \\
571 C-3 \\
571 B-4 \\
560 A-3 \\
582 A-4 \\
565 B-3 \\
563 B-2 \\
567 C-4 \\
567 A-4 \\
569 B-2 \\
567 C-2 \\
564 A-3 \\
555 B-1 \\
557 A-2 \\
531 C-3 \\
565 A-3 \\
569 A-2 \\
569 D-1\end{array}$ & $\begin{array}{c}I X-14 \\
\text { VIII-33 } \\
\text { VI-27 } \\
\text { VI-29 } \\
\text { VII-17 } \\
\text { VI-3 } \\
\text { VIII-23 } \\
\text { V-21 } \\
\mid X-36 \\
\mid I I-1 \\
\mid I I-4 \\
\| I I-6 \\
\mid I I-8 \\
\mid I I I-10 \\
\mid I I-11 \\
\| I I-12 \\
\| 1-1 \\
\| 1-3\end{array}$ & $\begin{array}{l}310 \\
311 \\
310 \\
311 \\
309 \\
310 \\
310 \\
310 \\
310 \\
310 \\
310 \\
311 \\
309 \\
309 \\
308 \\
310 \\
310 \\
309\end{array}$ & $\begin{array}{l}31 \\
31 \\
30 \\
31 \\
30 \\
31 \\
31 \\
31 \\
30 \\
31 \\
31 \\
31 \\
31 \\
30 \\
30 \\
30 \\
30 \\
30\end{array}$ & $\begin{array}{l}29 \\
29 \\
28 \\
29 \\
28 \\
29 \\
29 \\
29 \\
28 \\
29 \\
29 \\
29 \\
29 \\
28 \\
28 \\
28 \\
28 \\
28\end{array}$ & &. \\
\hline & Shlpr & int totals: & 18 & dements & & 557 & 550 & 514 & & \\
\hline
\end{tabular}




\begin{tabular}{|c|c|c|c|c|c|c|c|c|c|c|}
\hline \multirow{2}{*}{$\begin{array}{l}\text { Shippling } \\
\text { Document }\end{array}$} & \multirow{2}{*}{$\begin{array}{l}\text { Shipment } \\
\text { Date }\end{array}$} & \multirow{2}{*}{$\begin{array}{c}\text { Al } \\
\text { Can No. }\end{array}$} & \multicolumn{3}{|c|}{ Fuol Identification } & \multicolumn{3}{|c|}{ Fued Masses (grams) } & \multirow[b]{2}{*}{ Notes } & \multirow{2}{*}{$\begin{array}{l}\text { INEL } \\
\text { Can No: }\end{array}$} \\
\hline & & & Element & $\operatorname{Rod}$ & Location & Unclad & sotal U & U-235 & & \\
\hline \multirow[t]{2}{*}{ LAE-JWA-24 } & $8 / 21 / 68$ & 13 & $\begin{array}{l}E-304 \\
E-176 \\
E-244 \\
E-527 \\
E-288 \\
E-197 \\
E-510 \\
E-450 \\
E-268 \\
E-318 \\
E-358 \\
E-396 \\
E-109 \\
E-182 \\
E-175 \\
E-307 \\
E-533 \\
E-236\end{array}$ & $\begin{array}{l}571 D-4 \\
562 A-2 \\
572 B-4 \\
564 B-1 \\
571 C-4 \\
550 B-3 \\
556 B-3 \\
563 C-1 \\
572 C-1 \\
567 D-4 \\
565 C-1 \\
571 B-1 \\
550 B-2 \\
571 C-2 \\
570 C-4 \\
559 C-1 \\
531 D-4 \\
569 C-3\end{array}$ & $\begin{array}{l}\mid X-31 \\
\mid X-24 \\
\mid X-39 \\
\mid X-38 \\
\mid X-23 \\
\mid X-22 \\
I I I-5 \\
V-10 \\
\mid X-30 \\
\mid X-3 \\
\mid I-2 \\
V|I|-10 \\
\text { VIII-2 } \\
\mid X-11 \\
\text { VIII-38 } \\
|I|-7 \\
\mid X-34 \\
\mid X-48\end{array}$ & $\begin{array}{l}310 \\
310 \\
310 \\
309 \\
311 \\
310 \\
309 \\
311 \\
310 \\
310 \\
310 \\
310 \\
310 \\
306 \\
310 \\
310 \\
310 \\
310\end{array}$ & $\begin{array}{l}30 \\
31 \\
30 \\
31 \\
30 \\
30 \\
30 \\
30 \\
31 \\
30 \\
30 \\
31 \\
30 \\
31 \\
31 \\
31 \\
30 \\
30\end{array}$ & $\begin{array}{l}28 \\
29 \\
28 \\
29 \\
28 \\
28 \\
28 \\
28 \\
29 \\
28 \\
28 \\
29 \\
28 \\
29 \\
29 \\
29 \\
28 \\
28\end{array}$ & DDE & SN-19 \\
\hline & \multicolumn{2}{|c|}{ Shipment totals: } & 18 & dements & & 5576 & 547 & 511 & & . \\
\hline LAE-JWA-26 & $9 / 1868$ & 14 & $\begin{array}{l}E-474 \\
E-378 \\
E-293 \\
E-476 \\
E-486 \\
E-309 \\
E-332 \\
E-206 \\
E-188 \\
E-525 \\
E-111 \\
E-342 \\
E-519 \\
E-398 \\
E-232 \\
E-432\end{array}$ & $\begin{array}{l}572 A-3 \\
549 B-1 \\
531 C-4 \\
572 B-2 \\
582 C-2 \\
559 C-3 \\
565 C-2 \\
572 C-4 \\
532 D-3 \\
550 A-1 \\
531 C-1 \\
549 B-2 \\
564 B-4 \\
559 B-1 \\
565 C-5 \\
567 B-2\end{array}$ & $\begin{array}{c}I 1-4 \\
\mid X-28 \\
I X-29 \\
\text { VII-19 } \\
I I-3 \\
V-5 \\
\text { VIII-25 } \\
\text { X-15 } \\
\text { VIII-6 } \\
\text { VII-28 } \\
\mid X-42 \\
I-1 \\
I V-1 \\
I V-13 \\
\text { VI-24 } \\
\text { VIII-29 }\end{array}$ & $\begin{array}{l}140 \\
228 \\
176 \\
74 \\
276 \\
162 \\
129 \\
239 \\
121 \\
140 \\
111 \\
250 \\
173 \\
57 \\
112 \\
167\end{array}$ & $\begin{array}{l}14 \\
22 \\
17 \\
7 \\
27 \\
16 \\
13 \\
24 \\
12 \\
14 \\
11 \\
25 \\
17 \\
6 \\
11 \\
16\end{array}$ & $\begin{array}{l}13 \\
20 \\
16 \\
7 \\
25 \\
15 \\
12 \\
22 \\
11 \\
13 \\
10 \\
23 \\
16 \\
6 \\
10 \\
15\end{array}$ & $\begin{array}{l}\text { DDE } \\
\text { DDE } \\
\text { DDE } \\
\text { DDE } \\
\text { DDE } \\
\text { DDE } \\
\text { DDE } \\
\text { DDE } \\
\text { DDE } \\
\text { DDE } \\
\text { DDE, IS } \\
\\
\text { DDE }\end{array}$ & . \\
\hline \multirow[t]{2}{*}{$\cdot$} & \multicolumn{2}{|l|}{$\begin{array}{l}\text { irrad. cpsl } \\
\text { irrad. cpsl } \\
\text { imad. cpsl } \\
\text { irrad. cpsl } \\
\text { irrad. cpsl }\end{array}$} & $\begin{array}{l}117-1 \\
117-1 \\
115-2 \\
115-2 \\
82-1\end{array}$ & \multicolumn{2}{|c|}{$\begin{array}{l}\text { (NAA in-pile expt). } \\
\text { (NAA in-pile expt) } \\
\text { (NAA in-pile expt) } \\
\text { (NAA in-pile expt) } \\
\text { (NAA in-pile expt) }\end{array}$} & $\begin{array}{l}515 \\
86 \\
117 \\
155 \\
1149\end{array}$ & $\begin{array}{c}51 \\
9 \\
12 \\
15 \\
118\end{array}$ & $\begin{array}{c}48 \\
8 \\
11 \\
14 \\
110\end{array}$ & $\begin{array}{c}\text { pieces } \\
\text { pieces } \\
\text { pieces } 3-6 \\
\text { pieces } 1,2\end{array}$ & $\begin{array}{l}\text { SN-2O } \\
\text { SN-2O } \\
\text { SN-2O } \\
\text { SN-2O } \\
\text { SN-2O }\end{array}$ \\
\hline & \multicolumn{2}{|c|}{ Shipment fotals: } & $\begin{array}{c}16 \\
5\end{array}$ & \multicolumn{2}{|c|}{$\begin{array}{l}\text { elements } \\
\text { in-pile capsules }\end{array}$} & $\begin{array}{l}4577 \\
2022\end{array}$ & $\begin{array}{l}457 \\
205\end{array}$ & $\begin{array}{l}425 \\
191\end{array}$ & & \\
\hline \multirow[t]{2}{*}{ LAE-JWA-30 } & $2 / 26 / 69$ & 12 & $\begin{array}{l}E-351 \\
E-491 \\
E-340 \\
E-335 \\
E-316 \\
E-341 \\
E-302 \\
E-388 \\
E-492 \\
E-181\end{array}$ & $\begin{array}{l}582 A-1 \\
567 A-1 \\
565 D-3 \\
559 A-1 \\
571 C-1 \\
565 C-4 \\
572 B-3 \\
565 D-4 \\
558 D-1 \\
558 E-4\end{array}$ & $\begin{array}{l}\text { IV-12 } \\
\text { VII-29 } \\
\mid X-7 \\
\text { II-5 } \\
\text { VIII-36 } \\
\mid X-10 \\
I X-5 \\
\text { VI-25 } \\
\| I I-2 \\
\| 1-6\end{array}$ & $\begin{array}{l}275 \\
288 \\
288 \\
313 \\
289 \\
266 \\
299 \\
299 \\
265 \\
282\end{array}$ & $\begin{array}{l}27 \\
28 \\
28 \\
31 \\
29 \\
26 \\
29 \\
29 \\
26 \\
28\end{array}$ & $\begin{array}{l}25 \\
26 \\
26 \\
29 \\
27 \\
24 \\
27 \\
27 \\
24 \\
26\end{array}$ & $\begin{array}{l}\text { IS } \\
\pi T \\
T T \\
T T \\
\text { DDE } \\
\text { IS } \\
\text { IS } \\
T \pi\end{array}$ & SN-19 \\
\hline & \multicolumn{2}{|c|}{ ShIpment totals: } & 10 & elements & & 2864 & 281 & 261 & & \\
\hline
\end{tabular}




\begin{tabular}{|c|c|c|c|c|c|c|c|c|c|c|}
\hline \multirow{2}{*}{$\begin{array}{l}\text { Shipping } \\
\text { Document }\end{array}$} & \multirow{2}{*}{$\begin{array}{c}\text { Shipment } \\
\text { Date. }\end{array}$} & \multirow{2}{*}{$\begin{array}{c}\text { Al } \\
\text { Can No.: }\end{array}$} & \multicolumn{3}{|c|}{ Fuel Identification } & \multicolumn{3}{|c|}{ Fual Masses (grams) } & \multirow[b]{2}{*}{ Notes } & \multirow{2}{*}{$\begin{array}{l}\text { INEL } \\
\text { Can No. }\end{array}$} \\
\hline & & & Element & $\operatorname{Rod}$ & Location & Unclad & totu & U-235 & & \\
\hline \multirow[t]{2}{*}{ LุAE-JSB-02 } & $\begin{array}{l}6 / 20 / 73 \\
\text { packaged } \\
\text { with S8DR } \\
\text { can \#10 }\end{array}$ & 10 (S8DR) & $\begin{array}{l}E-339 \\
E-410 \\
E-515 \\
E-528 \\
E-171\end{array}$ & $\begin{array}{l}562 A-3 \\
561 D-2 \\
560 A-2 \\
531 A-1 \\
549 C-4\end{array}$ & $\begin{array}{l}\text { VIL-36 } \\
\text { Vil-27 } \\
\text { VII-18 } \\
I I I-9 \\
\mid X-6\end{array}$ & $\begin{array}{l}310.00 \\
299.00 \\
312.00 \\
128.00 \\
100.00\end{array}$ & $\begin{array}{c}30.50 \\
29.60 \\
30.48 \\
12.68 \\
9.88\end{array}$ & $\begin{array}{c}28.41 \\
27.57 \\
28.39 \\
11.82 \\
9.20\end{array}$ & IS & Al-10 \\
\hline & \multicolumn{2}{|c|}{ Partlal shipment totals: } & 5 & tements & & 1149.00 & 113.14 & 105.39 & & \\
\hline
\end{tabular}

S8ER reactor totals:

211 elements

$64301.00 \quad 6345.14 \quad 5925.39$

Reforences:

Data transcribed from archived copies of original shipping records

Fuel olement and fuel rod serial numbers cross-checked with QA document Hu64 (NAA-SR-8589, 03/01/64)

Notes: $\quad$ DDE $=$ detailed destructive examination, $\pi=$ tensile tests, is $=$ interface studies

Fuel element identifications from shipping records compared with, and in a few cases corrected to, tabulation in QA document Hu64

No SBER Fuel Data sheet available for mass sum comparisons 


\section{SNAP-8 DEVELOPMENTAL REACTOR (S8DR)}

Date went critical:

Date of shutdown:

Thermal power:

Thermal energy:

Time at power and temperature:

Operating location:

\author{
June 1968 \\ December 1969 (Li70, Li71) \\ 600-1000 kWt \\ $4.3 \times 10^{6} \mathrm{kWt}-\mathrm{h}$ \\ $6688 \mathrm{~h}$ at $600 \mathrm{kWt}\left(5575 \mathrm{~h}\right.$ at $1200^{\circ} \mathrm{F}, 1670 \mathrm{~h}$ at $\left.1300^{\circ} \mathrm{F}\right)$, \\ $429 \mathrm{~h}$ at $1000 \mathrm{kWt}\left(1150^{\circ} \mathrm{F}\right)$ \\ SSFL Building 059
}

\subsection{S8DR GENERAL DESCRIPTION}

The SNAP-8 developmental reactor assembly included the fuel elements, the core vessel assembly, and the reflector and control components assembly. The S8DR core contained 211 fuel elements cooled by eutectic NaK flowing axially between them. Each fuel element consisted of a cylindrical rod of fuel moderator; clad in Hastelloy. $\mathrm{N}$ tubing.

The fuel-moderator material was composed of a hydrided alloy of zirconium and fully enriched $(93.15 \pm$ $0.15 \%{ }^{235} \mathrm{U}$ ). The uranium content constituted $10.5 \pm 0.3 \mathrm{wt}$. \% of the unhydrided alloy. This material also contained $0.15 \pm 0.05 \mathrm{wt}$. \% carbon, added in the form of zirconium carbide $(\mathrm{ZrC})$ prior to the initial arc melting of the zirconium-uranium alloy. This carbon additive resulted in a refinement of the alloy grain structure and a consequent improvement in the production yield during the hydriding process. .

The fuel rods were hydrided to hydrogen atom densities between 5.97 and $6.15 \times 10^{22}$ atoms $/ \mathrm{cm}^{3}$, with an average for all 211 rods of $6.05 \times 10^{22}$. At the operating temperatures characteristic of S8DR, hydrogen pressures in the range to 0.1 or $0.2 \mathrm{MPa}$ were produced in the annulus between the fuel rod and the cladding. To minimize hydrogen loss from the fuel element, the interior surface of the cladding was coated with a ceramic material. This coating reduced the leak rate of hydrogen through the cladding wall by a factor of about 1000 . The ends of each cladding tube were enclosed by Hastelloy $N$ end caps. These end closures were welded to the tubing. The ceramic coating on the final end closure was fused to that on the tubing to form a continuous hydrogen seal.

The active length of the S8DR fiel.element (i.e., the length of the fuel rod) was $0.427 \mathrm{~m}$ (16.825 in.). An axial gap of $6.1 \mathrm{~mm}(0.24 \mathrm{in})$ between the top surface of the fuel rod and the ceramic layer on the end cap was designed to accommodate axial fuel swelling and to minimize the heat transfer effect due to fission gas accumulation. The 13.4-mm- (0.529-in.-) diameter fuel rod was separated from the 0.05-Inm(0.002-in.-) thick ceramic layer on the cladding by a nominal hot diametral gap of $0.19 \mathrm{~mm}(0.007 \mathrm{in}$.) that served to accommodate fuel swelling. The Hastelloy $\mathrm{N}$ tubing had an ID of $13.7 \mathrm{~mm}(0.540 \mathrm{in}$.) and . a nominal thickness of $0.287 \mathrm{~mm}$ (0.011 in.).

Changes in the fuel rod design from S8ER, including increased radial and axial clearances between fuel rods and cladding to accommodate fuel growth, and redesigned fuel element end caps, to alleviate stress cracking, were based on the post-irradiation observations of cladding cracks in the S8ER fuel elements. The S8ER post-irradiation evaluation also resulted in a change in the fuel element hydrogen permeation barrier to a ceramic coating more resistant to thermal cycling. One of the major differences between the S8ER and S8DR fuel elements was the closure end plug. For S8ER this was a two-piece assembly, while for S8DR it was a single piece. 
Post-irradiation examination of S8DR showed 72 of the 211 fuel elements had small cladding cracks typical of stress-rupture. These were attributed to excessive cladding strain due to excessive fuel swelling, resulting from fuel temperatures an estimated $100^{\circ} \mathrm{F}$ higher than the design values in localized core regions. The higher temperatures were attributed to the agglomeration of entrained gas bubbles in the coolant and fuel element clustering. There was no damage in regions of nominal coolant flow.

General descriptions of the S8DR are given in AN76 and An83, with a schematic drawing and a summary table of reactor characteristics in An83.

\subsection{S8DR REACTOR AND FUEL IDENTIFICATION}

Reactor: $\quad$ SNAP-8 Developmental Reactor (S8DR)

Also identified as: S8DS (earlier designation, as noted in Sw67)

Core fuel Identification: S8DR (same as reactor name)

Reactor designer, builder, operator: Atomics Intemational

Reactor owner: Atomic Energy Commission (now DOE)

Fuel designer, builder: Atomics Intemational

Fuel owner: Atomic Energy Commission (now DOE)

\subsection{S8DR DESIGN REACTOR PHYSICS AND CORE DESCRITTION}

Sw67 Reanalysis of the S8DR reactor to redesign core (after fuel:manufacture. but before cladding and core assembly) to incorporate information gained from S8ER test and new fuel irradiation test data

Fuel elements/assemblies: 211 fuel elements

Design neutron flux:

Design neutron energy: Mean neutron fission energy about $0.26 \mathrm{eV}$ (Sw69)

Core map and element locator:

Li71 Core map (Fig. 26)

Li70 Core map showing locations of cracked fuel elements

\subsection{S8DR FUEL FABRICATION INFORMATION}

Fuel specifications and drawings:

Do68 Complete list of engineering drawings, specifications, test procedures, and manufacturing instructions for the S8DR fuel fabrication (Table 1, 46 documents)

Mo69 Fuel element drawings (provided as reference for post-irradiation analyses)

(Most are available from the Rocketdyne Advanced Power Systems Technical Data Center; they should be ordered by revision number)

Drawing S8DR-18001

Drawing S8DR-18008
"Fuel Element Assembly" (01/67)

"Fuel Rod-Fuel Element" (01/67)

Drawing S8DR-18011, Rev. A Engineering release drawing - fuel element configuration 
Fuel fabrication and quality control:

Ma64 Fabrication sequence and processes for vacuum arc melting and extruding the $\mathrm{Zr}-\mathrm{U}$ alloy.

La67 Fabrication sequence and procedures for fabricating the hydrogen barrier ceramic powder

De67 Specification for chemically etching the S8DR fuel to reduce its diameter

Mc67 Process flow sheets - S8DR final fuel element assembly (manufacturing planning sheets and procedures to be used)

Do68 List of dimensional discrepancies in accepted fuel rods (Table 2)

Do68 Appendix IX Fuel element assembly closure weld and element proof tests (Part 1), final acceptance tests and inspections (Part 2), and fuel rod inspection and traceability record (Part 3)

Appendix X Fuel element hydrogen leak rates

Appendix XI . Completed fuel element release notices

Appendix XII Fuel element closure weld process and operator qualifications

Sw70 Film radiographic method for determining $\mathrm{H} / \mathrm{Zr}$ in S8DR-type fuel (not sensitive enough for required application)

Fuel cladding, inner coatings, and other non-fuel materials:

Mc67a Process flow sheets - S8DR cladding tube fabrication (manufacturing planning sheets and procedures to be used)

Ma67 Process flow sheets - closure (cup) plug fabrication (manufacturing planning sheets and procedures to be used)

Do68 Appendix I Hastelloy'N supplier.end cap bar stock chemistry, mechanical properties, and internal soundness

-Appendix II: Hastelloy $\mathrm{N}$ supplier clad tubing chemistry, mechanical properties, and intermal soundness

Appendix III Tube-to-first end cap inspection and raw material traceability data.

Appendix IV Chromized cladding tube assembly inspection and traceability

Appendix V Ceramic-coated tube assembly test and inspection data

Appendix VI Ceramic coating and as-machined closure end plug test, inspection, and traceability records (incl. $\mathrm{Sm}_{2} \mathrm{O}_{3}$ and boron contents - other information was omitted due to classification)

Appendix VII Chromized closure end plug test, inspection, and traceability records Appendix VIII. Coated closure end plug test, inspection, and traceability records

Mc69 Fuel rod fabrication sequence and procedures from raw material through finish-machined and hydrided fuel alloy

Mc69a Summarizes the overall fuel element fabrication (information in the manufacturing process flow sheets, with yields, after fuel element fabrication)

Da70 $\mathrm{Cr}_{2} \mathrm{C}$ embrittlement of Hastelloy- $\mathrm{N}$ cladding during chromizing operation (identifies certain elements having this problem, shown in core map)

Potential fuel chemical reactions:

Potential RCRA-regulated materials:

Quantities of materials:

See shipping spreadsheets (fuel rods, $U,{ }^{235} \mathrm{U}$ )

Mi70b, Sc71 Some fuel losses occurred during hot-laboratory cutting for post-irradiation examination, with the calculated waste assigned to scrap cans; calculated values given in Mi70b 
Fuel assembly identification methods:

Ar77 Specification for marking parts and assemblies (dated 1977 but replaces a specification that may have been used for the fuel element components of several of the SNAP cores)

Drawing S8DR-18008 Calls out fuel rod identification by electric etching on the end of the small-diameter portion of the rod

\subsection{S8DR OPERATIONAL HISTORY}

Core Operating History:

La68, La68a, La68b S8DR Operations Manual (little relevant information)

Ha69 Selected operating parameters for 1-19-69 to 4-28-69, including reactor power and reactivity data

Li71 Summary. of operating history (Fig. 6); power operating history (Fig. A-1); hydrogen loss history (Fig. A-2); inlet and outlet temperature history (Fig. A-3)

Core neutron flux profile:

Operation abnormalities:

Li71 Scrams included in operating history (Fig. 6)

Core shut-down date:

Li70 Shut down around the middle of December 1969, to investigate an observed reactivity loss rate and a fission product inventory in the NaK coolant

Core discharge date:

Li70 Allowed to cool for a few months after shut-down and delivered to the AI Hot Laboratory - (AIHL).on March 22, 1970

\subsection{S8DR POST-IRRADIATION PROPERTIES AND EXAMINATION}

Available source data include extensive individual element-by-element fuel rod and fuel element dimensional data (length, diameter, ovality, length, bow), visual examination information, gamma scan data (strip charts), and crack data from pre- and post-irradiation examinations. These data are contained in individual file folders rather than in report format.

Tr69 Computerized selected pre-irradiation quality data from Do68 for use by post-irradiation analysts

Mi69 Preliminary planning and cost estimates for S8DR hot cell examination

Mi69a S8DR examination planning document for Al Hot Laboratory

. Sc70 S8DR fuel element sample numbering system (for sectioned samples)

Li70 S8DR screening examination

Li70a S8DR screening examination weekly status reports (No. 1-16)

Mi70 Selection of S8DR fuel elements for detailed post-irradiation examination, with core map locations

Mi70a S8DR detailed examination progress reports (No. 1-10), including graphs, photos, scans .

Li71 Fuel-growth data table with extensive pre- and post-test fuel properties

Visual observations:

Li70 Screening examination cell-window and in-cell photographs of fuel elements with tabulations of results 


\section{Dimensions:}

M069 Pre-irradiation dimensional and density data for selected fuel elements

Li70 Screening examination measurements of length, diameter, and longitudinal bow of fuel elements

Mi70c Screening examination fuel rod dimensional data from neutron radiography

Li71 Fuel growth, density, dimensions

Metallurgical states of materials:

Li71 Summary of metallurgical phase information

Cladding defects:

Li70 Screening examination of clad cracking, including core map showing locations of cracked fuel elements

Li71 Summary of cladding condition

Bu70 Statistical evaluation of fuel-clad gap and crack length from S8DR fuel elements

Corrosion or chemical contamination:

Li71 Summary of locations where coating contacted fuel material

Va70 Initial report on metallic coating that developed on outside of the fuel cladding

Ei70 More detailed discussion of coating that developed on outside of the fuel cladding

C071 Electron microprobe $x$-ray analysis of three irradiated S8DR fuel specimens, providing chemical analysis of glass-fuel interface

Hydrogen effects:

Li71 Fuel element hydrogen leak rates

Burnup:

Ro70. Fuel burnup calculations, core average for ${ }^{235} U$ and ${ }^{238} U$

Fission products:

Li70 Screening examination gamma scans of fuel elements

Transuranics:

Ro70 Fuel bumup calculations, including estimates of ${ }^{236} \mathrm{U}$ and ${ }^{239} \mathrm{Pu}$

(can be calculated from available reactor information)

Activation products:

Decay heat generation:

Radiation level decay curves:

Alpha contamination:

(not relevant for the declad fuels)

\subsection{S8DR ON-SITE STORAGE HISTORY}

The S8DR fuel elements were delivered from the reactor facility to the Atomics International Hot Laboratory (AIHL) on March 22, 1970 (Li70), about three months after shut-down. The only fuel disassembly that took place was for hot cell examination, which is covered in the post-irradiation examination section. The disassembled components were then stored at the AI's Radioactive Materials Disposal Facility (RMDF) in dry storage vaults following post-irradiation examination prior to shipment 
to INEL. They were stored in air at both facilities; there were no wet-storage facilities available at AI. No detailed storage history documentation is available.

Ke70 Criticality study for fuel element transfer from core to AlHL for post-irradiation analysis

Ke71 Criticality study for dry storage of S8DR fuel elements in RMDF vault no. 2

Mc71, Mc71a, Sc73:

Information on the batching, canning, and shipping of S8DR fuel from the AIHL to the RMDF, including a listing of all elements by core position and whether each was disassembled for examination

\subsection{S8DR SHIPPING RECORDS}

The shipping records for the S8DR fuel shipments to INEL were reviewed in detail. The original records are difficult to read, and were transcribed onto the S8DR spreadsheet that is reproduced at the end of this section. The spreadsheet lists the core location, fuel rod identification, unclad fuel rod mass,.total uranium mass, and ${ }^{235} U$ mass for each fuel element, plus the shipping document number, shipment date, Atomics International can number, and probable INEL aluminum can number. The latter is base on document copies received from INEL as part of the current review activity. A total of 211 irradiated and 2 archived (unirradiated) S8DR fuel elements were shipped to INEL.

- The fuel element and fuel rod identifications were compared with QA traceability document Do68. Three transcription errors were found on the shipping documents and are noted in the spreadsheet (Notes 1,4,6).

The mass totals shown on the spreadsheet were calculated from the individual recorded fuel element data. They were compared with the transfer document mass summaries that were filed with the shipping documents. The transfer document mass summary was found to have two typographical errors (spreadsheet Notes 5,7) and two offsetting 2-g mass errors (spreadsheet Note 8). One remaining discrepancy is a 0.06-g difference in the AI Can No. 7 total fuel mass, where the sum of the individual fuel rod masses is $0.06 \mathrm{~g}$ lower than the transfer document summary value (spreadsheet Note 2). This difference is also reflected in the total S8DR fuel mass sum. This is likely to be due to an addition or transcription error in the transfer document sum, but we cannot rule out a $0.06-\mathrm{g}$ recording error in an individual element mass.

\subsection{S8DR REFERENCES}

AN76 Anonymous, "Zirconium Hydride (SNAP) Reactor Space Power Programs. Summary of Major Activities and Accomplishments," Rockwell Intemational Energy Systems Group (June 1976)

An83 R. V. Anderson, et al., "Space Reactor Electric Systems. Subsystem Technology Assessment," Rockwell International Energy Systems Group Report ESG-DOE-13398 (March 1983)

Ar77 D. V. Amold, C. C. Woolsey, and W. H. Friske, "Specification for Marking," Atomics International Specification N001A0104001 (June 1977) (7 pages)

Bu70 D. S. Burgess, "Statistical Evaluation of the Fuel-Clad Gap and Crack Length from S8DR Fuel Elements," Atomics Intemational Technical Information Document TI-568-24-058 (June 1970) (14 pages) 
Co71 L. Cooper, "Results from Abbreviated EMP Examination of Three S8DR Irradiated Fuel Specimens," Atomics International Technical Information Document TI-653-240-003 (July 1971) (7 pages)

Da70 N. F. Davies, "S8DR Examination," Atomics Intemational Technical Information Document TI568-24-049 (April 1970) (3 pages)

De67 W. F. Dennison and P. J. Fessia, "Fuel Element Assembly, S8DR," Atomics International Specification ST0622NA0041 (May 1967) (14 pages)

Do68* C. Donnelly and W. Nagel, "S8DR Fuel Element Quality Assurance Record," Atomics Intemational Technical Data Record AI-AEC-TDR-12702 (March 1968) (137 pages)

Ei70 R. L. Eichelberger, "Coating on S8DR Fuel Cladding," North American Rockwell Corporation Aerospace and Systems Group Intemal Letter dated 3 August 1970 (6 pages)

Ha69 F. J. Halfen, "Summary of Selected S8DR Operating Data from 1-19-69 to 4-28-69," Atomics Intemational Technical Information Document TI-696-13-033 (May 1969) (19 pages)

Ke70 N. Ketzlach, "Criticality Study - S8DR Core Disassembly," Atomics International Technical Information Document TI-568-24-041 (January 1970) (15 pages)

Ke71 N. Ketzlach, "Storage of S8DR'Fuel at RMDF," Atomics International Technical Information Document TI-568-240-083 (May 1971) (4 pages)

La67 K. Langrod, "Process Flow Sheets - S8DR Hydrogen Barrier Material Fabrication," Atomics Intemational Technical Data Record NAA-SR-MEMO-12469 (May 1967) (27 pages)

La68 E. M. Larson, "Radiological Safety and Hazardous Materials Handbook for Building 059," Atomics Intemational Technical Data Record AI-AEC-12682 (April 1968) (part of S8DR Operations Manual)

La68a E. M. Larson, "S8DR Operations Manual," Atomics Intemational Technical Data Record AI-AEC12683 (May 1968) (part of S8DR Operations Manual)

La68b E. M. Larson, "SNAP Ground Prototype Test Facility (Building 059)," Atomics International Technical Data Record AI-AEC-12684 (April 1968) (part of S8DR Operations Manual)

Li70 A. F. Lillie, "The S8DR Screening Examination," Atomics International Technical Information Document TI-568-240-068 (October 1970) (112 pages)

Li70a A. F. Lillie and K. J. Miller, "S8DR Screening Examination Weekly Status Reports," Atomics Intemational Technical Information Documents: \#1 (TI-568-24-046, 20 March 1970, 5 pages), \#2 (TI-568-24-048, 27 March 1970, 8 pages), \#3 (TI-568-24-050, 3 April 1970, 8 pages), \#4 (TI568-24-051, 10 April 1970, 13 pages), \#5 (TI-568-24-052, 17 April 1970, 27 pages), \#6 (TI-56824-053, 24 April 1970, 22 pages), \#7 (PSR-568-24-001, 1 May 1970, 17 pages), \#8 (PSR-568-24002, 8 May 1970, 13 pages), \#9 (PSR-568-24-003, 15 May 1970, 15 pages), \#10 (PSR-568-24004, 22 May 1970, 31 pages), \#11 (PSR-568-24-005, 29 May 1970; 19 pages), \#12 (PSR-568-24006, 5 June 1970, 31 pages), \#13 (PSR-568-24-007, 12 June 1970, 38 pages), \#14 (PSR-568-24 
$-008,19$ June 1970, 29 pages), \#15 (PSR-568-24-009, 26 June 1970, 26 pages), and \#16 (PSR568-24-010, 3 July 1970, 22 pages)

Li71* A. H. Lillie and V. L. Rooney, Jr., "The SNAP 8 Developmental Reactor (S8DR) Post-Test Examination," Atomics International Report AI-AEC-13003 (June 1971) (93 pages)

Ma64 C. A. Martin and W. H. Timmerman, "Process Flow Sheet for SNAP 8DS Melting and Extruding," Atomics International Technical Data Record NAA-SR-MEMO-9630 (March 1964) (17 pages)

Ma67 C. A. Martin, "Process Flow Sheets - S8DR Cup Plugs," Atomics International Technical Data Record NAA-SR-MEMO-12470 (May 1967) (18 pages)

Mc67 D. T. McClelland, "Process Flow Sheets - S8DR Fuel Element Fabrication," Atomics International Technical Data Record NAA-SR-MEMO-12473 (May 1967) (19 pages)

Mc67a D. T. McClelland, K. Langrod, and C. A. Martin, "Process Flow Sheets - S8DR Cladding Tube Fabrication," Atomics Intemational Technical Data Record NAA-SR-MEMO-12475 (May 1967) (67 pages)

Mc69 D. T. McClelland, "S8DR Fuel Rod Fabrication," Atomics International Technical Data Record AI-AEC-TDR-12775 (January 1969) (43 pages)

Mc69a D. T. McClelland, "SNAP 8 Development Reactor Fuel Element Fabrication," Atomics International Report AI-AEC-12806 (June 1969) (55 pages)

Mc71 W. R. McCurnin, "S8DR Fuel Canning and Storage," North American Rockwell Intemal Letter dated 22 June 1971 (5 pages)

Mc71a W. R. McCumin, "FINAL S8DR Fuel Canning and Storage," North American Rockwell Intemal Letter dated 30 June 1971 (5 pages)

Mi69 K. J. Miller, "S8DR Examination Planning Document for AIHL," Atomics International Test Plan TP-568-24-004 (November 1969) (51 pages)

Mi69a K. J. Miller, "S8DR Examination Planning Document for AIHL," Atomics International Technical Information Document TI-568-24-037 (December 1969) (42 pages)

Mi70 K. J. Miller, "Selection of S8DR Fuel Elements for the Detailed Postirradiation Examination," Atomics International Technical Information Document TI-568-24-061 (June 1970) (11 pages)

Mi70a K. J. Miller, et al., "S8DR Detailed Examination Progress Report," Atomics International Program Status Reports: Number 1 (PSR-568-240-011, September 1970, 36 pages), Number 2 (PSR-568240-012, October 1970, 62 pages), Number 3 (PSR-568-240-013, November 1970, 54 pages), Number 4 (PSR-568-240-014, December 1970, 11 pages), Number 5 (PSR-568-240-015, January 1971, 15 pages), Number 6 (PSR-568-240-016, February 1971, 44 pages), Number 7 (PSR-568240-017, March 1971, 26 pages), Number 8 (PSR-568-240-018, May 1971, 23 pages), Number 9 (PSR-653-240-001, July 1971, 92 pages), and Number 10 (PSR-653-240-002, July 1971, 29 pages) 
Mi70b K. J. Miller, "S8DR Fuel Accountability Losses at AIHL," North American Rockwell Corporation Aerospace and Systems Group Internal Letter dated 21 December 1970 (2 pages)

Mi70c M. Mike, "Fuel Rod Dimensional Data/Plots From N-Ray Results - S8DR Screening Examination," Atomics International Technical Information Document TI-568-24-066 (July 1970) (213 pages)

Mo68 L. Morrison and E. L. Babbe, "S8ER Fuel Rod and Fuel Element Pre-Irradiation Measurements," Atomics Intemational Technical Information Document TI-S8DR-28-012 (May 1968) (16 pages)

Ro70 H. Rood, "S8DR Fuel Burnup and Transmutation Data," Atomics Intemational Technical . Information Document TI-568-24-063 (July 1970) (5 pages)

Sc70 F. G. Schmidt, "S8DR Fuel Element Sample Numbering System," North American Rockwell Corporation Aerospace and Systems Group Intemal Letter dated 13 July 1970 (2 pages)

Sc71 F. G. Schmidt, "S8DR Fuel Cutting Losses Assigned to Scrap at AIHL," North American Rockwell Corporation Aerospace and Systems Group Internal Letter dated 1 July 1971 (1 page)

Sc73 F. G. Schmidt, "Shipment of SNAP Fuel to RMDF," North American Rockwell Internal Letter dated 16 March 1973 (2 pages)

Sw67 L. D. Swenson, "S8DR Core Performance Evaluation," Atomics International Report NAA-SR12482 (August 1967) (75 pages)

Sw69* L. D. Swenson; "SNAP 8 Development Reactor Nuclear Analysis," Atomics International Report AI-AEC-12864 (October 1969) . (75 pages)

Sw70 V. A. Swanson, "Neutron Radiography as a Means for Determining $H / Z r$ in SNAP-Type Fuel Elements," Atomics International Technical Infọmation Document TI-568-24-056 (May 1970) (16 pages)

Tr69 J. Tribfelner, "S8DR Pre-Irradiation Data File and Corresponding Computer Printout," Atomics Intemational Technical Information Document TI-568-24-035.(November 1969) (46 pages)

Va70 R. Van Houten, "First Status Report (to 5:00 p.m., April 3, 1970) on the Coatings on S8DR Fuel Elements," North American Rockwell Corporation Aerospace and Systems Group Internal Letter. dated 7 April 1970 (3 pages) 


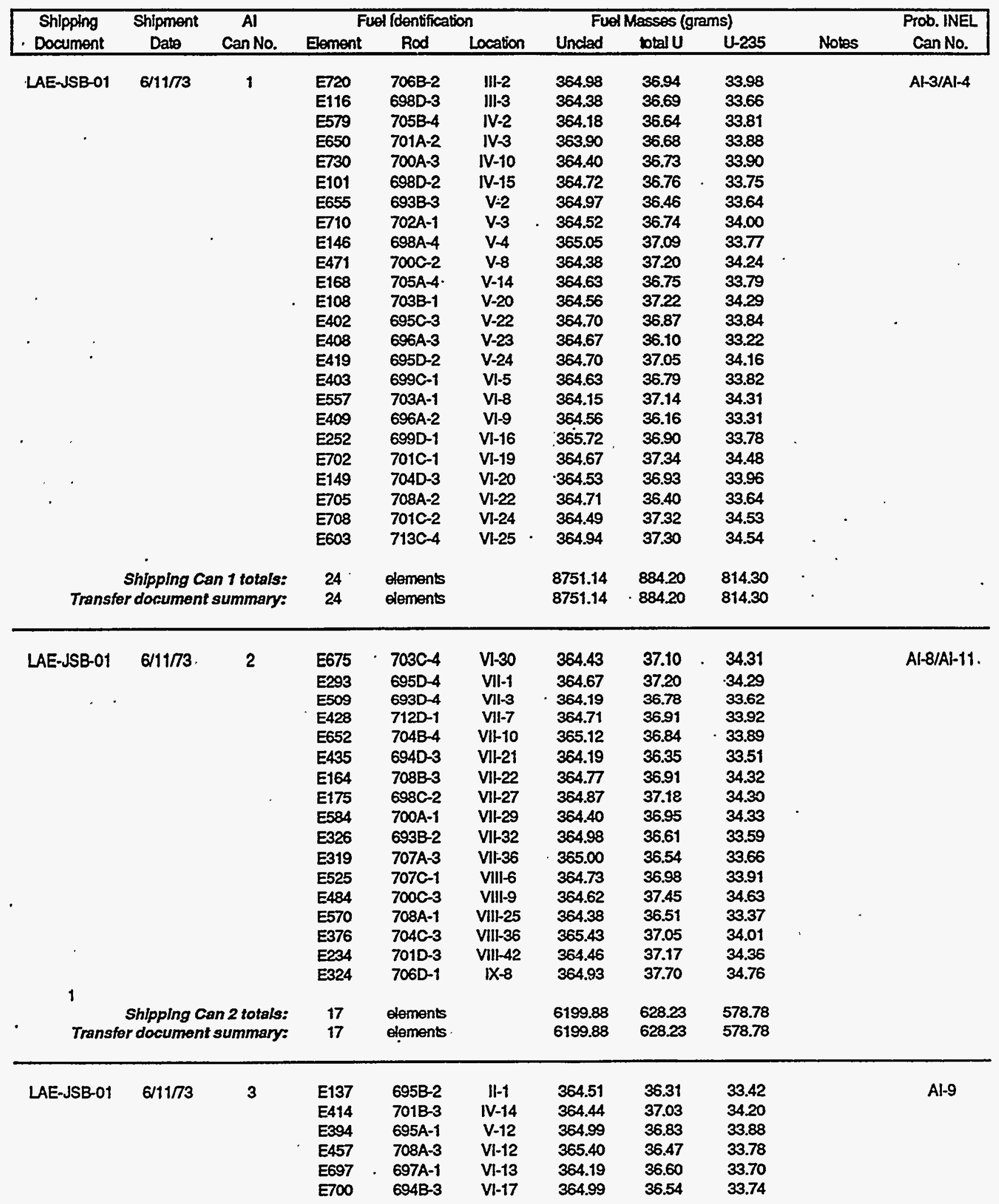




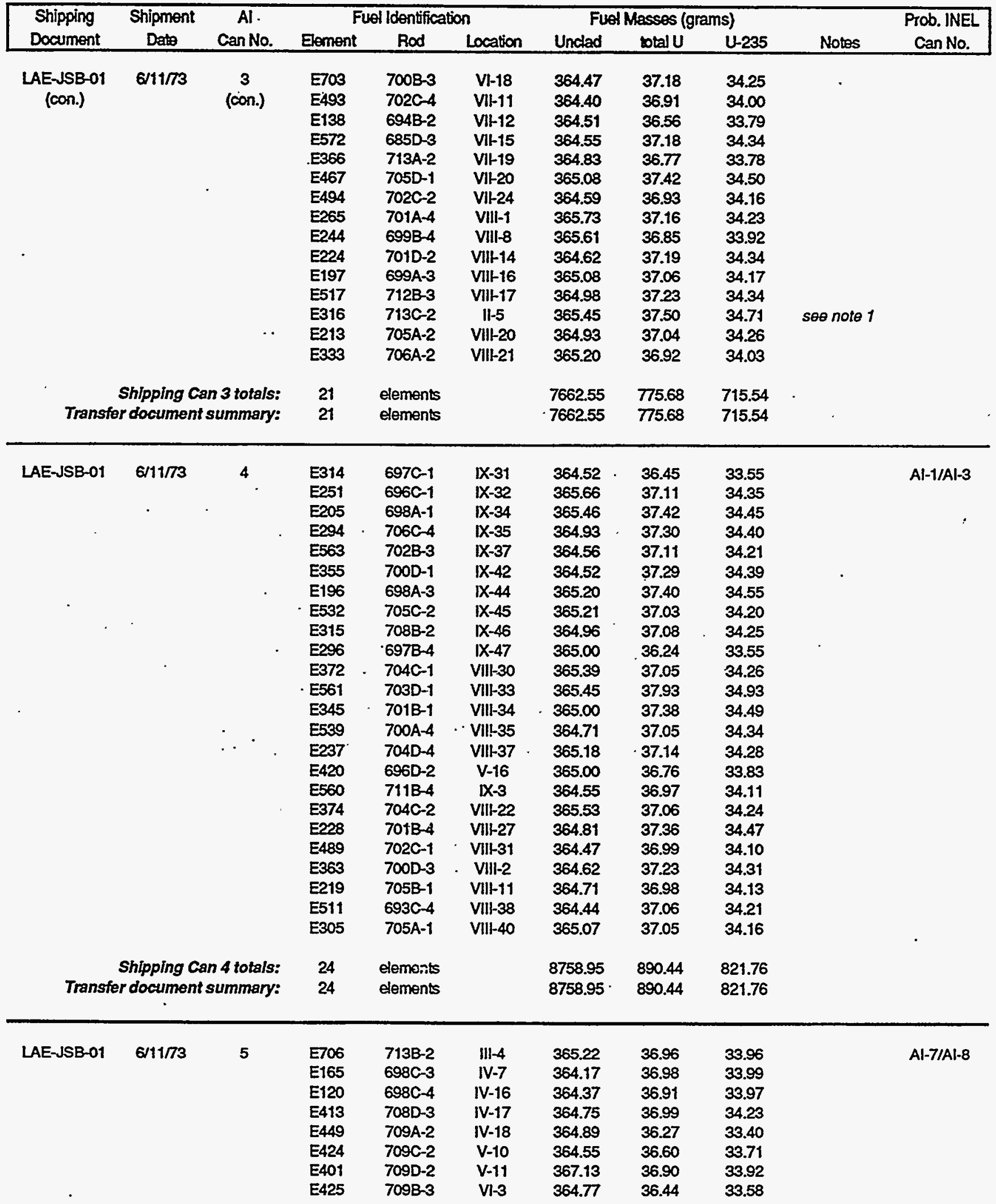




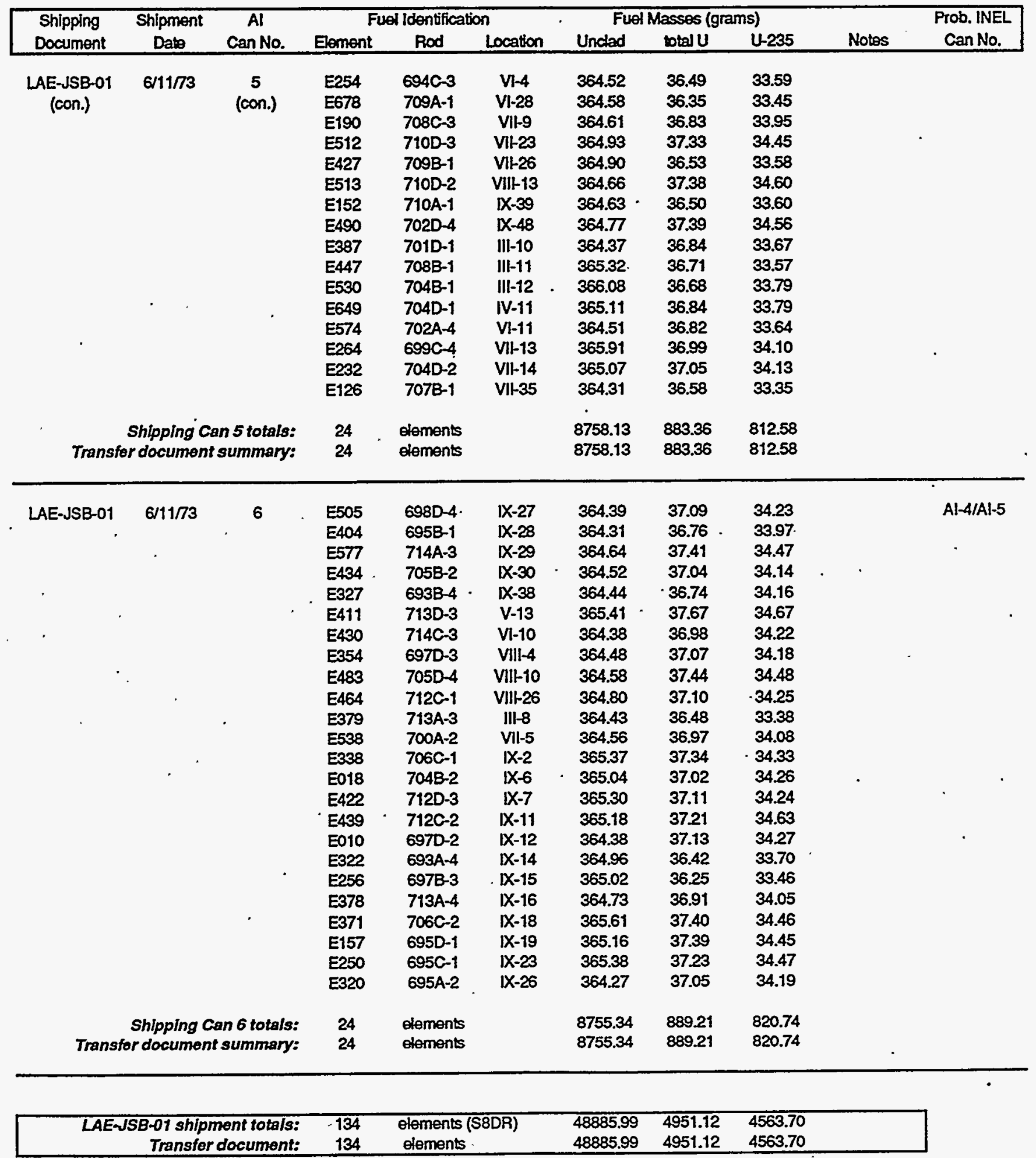




\begin{tabular}{|c|c|c|c|c|c|c|c|c|c|c|}
\hline \multirow{2}{*}{$\begin{array}{l}\text { Shipping } \\
\text { Document }\end{array}$} & \multirow{2}{*}{$\begin{array}{l}\text { Shipment } \\
\text { Dade }\end{array}$} & \multirow{2}{*}{$\begin{array}{c}\text { Al } \\
\text { Can No. }\end{array}$} & \multicolumn{3}{|c|}{ Fuel Identification } & \multicolumn{3}{|c|}{ Fued Masses (grams) } & \multirow{2}{*}{ Notes } & \multirow{2}{*}{$\begin{array}{l}\text { Prob. INEL } \\
\text { Can No. }\end{array}$} \\
\hline & & & Element & Rod & Location & Unclad & otal U & U-235 & & \\
\hline \multirow[t]{19}{*}{ LAE-JSB-02 } & $6 r 2073$ & 7 & E133 & $712 D-4$ & $V 1-26$ & 297.50 & 30.05 & 27.69 & 14 pos & Al-6/Al-7 \\
\hline & & & E128 & 6930-1 & V1-29 & 364.48 & 36.74 & 33.84 & 3 pes & \\
\hline & & & E1to & $696 \mathrm{~B}-1$ & IV-4 & 363.37 & 36.45 & 33.41 & 5 pos & \\
\hline & & . & E631 & $703 \mathrm{C}-2$ & $v-7$ & 362.63 & 36.81 & 33.90 & 6 pas & \\
\hline & & & E302 & $699 A-2$ & $V-17$ & 362.34 & 36.56 & 33.62 & $1 p c$ & \\
\hline & & & E391 & $695 A-4$ & $V-18$ & 363.02 & 36.63 & 33.40 & 4 pas & \\
\hline & & & E383 & $713 B-3$ & $V-21$ & 363.33 & 36.88 & 34.04 & 3 pos & \\
\hline & . & & E463 & $7030-3$ & VI-14 & 363.27 & 37.53 & 34.95 & 3 pas & \\
\hline & & & E267 & $699 \mathrm{C}-3$ & VII-6 & 364.36 & 36.84 & 33.97 & 3 pas & \\
\hline & & & E711 & $7128-4$ & VII-17 & 362.86 & 36.94 & 34.04 & 2 pas & \\
\hline & & & E199 & $699 A-1$ & VI-18 & 363.55 & 36.83 & 34.00 & $1 \mathrm{pc}$ & \\
\hline & & & E230 & $701 c-4$ & VII-15 & 363.16 & 37.33 & 34.24 & $1 \mathrm{pc}$ & \\
\hline & & & E526 & $701 A-1$ & VHI-19 & 363.70 & 36.95 & 34.03 & $1 p c$ & \\
\hline & & & E365 & $7000-4$ & VIII-23 & 363.17 & 37.08 & 34.10 & 3 pos & \\
\hline & & . & E308 & $707 B-3$ & VIIt-29 & 362.85 & 36.50 & 33.84 & $1 p c$ & \\
\hline & & & E571. & $706 A-1$ & VIII-32 & 362.76 & 36.68 & 34.02 & 5 pas & \\
\hline & & & E233 & $7010-4$ & VIII-28 & 364.56 & 37.19 & 34.30 & 2 pas & . \\
\hline & & & E321 & $706 c-3$ & IX-24 & 365.06 & 37.31 & 34.37 & & \\
\hline & & & E274 & $699 B-1$ & VIII-41 & 364.34 & 36.73 & 33.92 & $2 p a s$ & \\
\hline - & & & E454 & $712 A-1$ & IV-12 & 360.05 & 36.55 & 33.79 . & $17 \mathrm{pcs}$ & \\
\hline Transfo & $\begin{array}{l}\text { Shlpping C } \\
\text { r documen }\end{array}$ & $\begin{array}{l}\text { n7totals: } \\
\text { summary: }\end{array}$ & $\begin{array}{l}20 \\
20\end{array}$ & $\begin{array}{l}\text { elements } \\
\text { elements. }\end{array}$ & - & $\begin{array}{l}7200.36 \\
7200.42\end{array}$ & $\begin{array}{l}730.58 \\
730.58\end{array}$ & $\begin{array}{l}673.47 \\
673.47\end{array}$ & $\begin{array}{c}\text { see note } 2 \\
19 \text { sectioned }\end{array}$ & \\
\hline \multirow[t]{20}{*}{ LAE-JSB-02 } & $6 / 20 / 73$ & 8 & E386 & 701B-2 & VI-1 & 223.91 & 22.84 & 21.12 & 19 pcs & Al-2 \\
\hline & & & E131 & 693D-3 & IV-13 & 325.84 & 32.71 & 30.40 & 14 pos & \\
\hline & . & . & E657 & $697 c-4$ & VI-23. & 267.77 & 26.59 & 24.46 & 16 pas & \\
\hline & & & E396 & $7128-2$ & $\| I \mid-1$ & 356.90 & 36.08 & 33.15 & $5 \mathrm{pos}$ & - \\
\hline & . & - & E412 & 6930-2. & IV-5 & 359.46 & 36.09 & 33.47 & 5 pos & \\
\hline & & & $E 673$ & $705 \mathrm{C}-3$ & $V-6$ & 359.86 & 36.09 & 33.14 & 8 pas & \\
\hline & & & E472 & $706 A-4$ & $v-19$ & 362.44 & 36.57 & 33.54 & 10 pas. & \\
\hline & & & E531 & $703 D-4$ & V1-6 & 363.91 & 37.59 & 34.63 & 9 pcs & 3 \\
\hline & & & E699 & $694 A-4$ & . VI-15 & 361.70 & 36.03 & 33.26 & $2 p a s$ & \\
\hline & & & E140 & $706 D-3$ & VII-2 & 301.27 & 31.00 & 28.65 & 19 pas & \\
\hline & & & E061 & $698 B-4$ & VIII-5 & 326.67 & 33.16 & 30.48 & see note 3 & \\
\hline & & & E738 & $702 A-3$ & VIII-39 & 361.73 & 36.68 & 33.92 & 2 pos & \\
\hline & & & E151 & 696D-1. & $. X-10$ & 362.20 & 36.80 & 33.92 & 2 pas & \\
\hline & * & & E334 & $695 C-2$ & $1 x-43$ & 362.45 & 36.93 & 34.26 & 2 pes & . \\
\hline & & & E545 & $704 A-2$ & $\mid X-20$ & 304.21 & 30.94 & 28.49 & $18 p c s$ & \\
\hline & & & E328 & $6968-3$ & $1 X-40$ & 301.95 & 30.59 & 28.22 & 18 pas & \\
\hline & & & E723 & $690 B-4$ & VIII-3 & 253.27 & 25.61 & 23.65 & 14 pes & \\
\hline & & & E271 & $699 A-4$ & VII-8 & 364.22 & 36.90 & 33.96 & 11 pos & \\
\hline & & & E111 & $698 D-1$ & VI-2 & 327.46 & 33.14 & 30.57 & 14 pas & \\
\hline & & & E127 & $6958-3$ & $:-1$ & 362.98 & 36.15 & 33.30 & $2 p a s$ & \\
\hline \multirow[b]{2}{*}{ 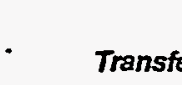 } & Shlpping C & In 8 totals: & 20 & elements & & 6610.20 & 668.49 & 616.59 & & \\
\hline & rocumen & summary: & 20 & elements & & 6610.20 & 668.49 & 616.59 & 20 sectioned & \\
\hline \multirow[t]{7}{*}{ LAE-JSB-02 } & $620 / 73$ & 9 & E132 & $695 \mathrm{C}-4$ & VII-25 & 363.31 & 36.88 & 33.87 & 2 pieces & Al-10/Al-12 \\
\hline & & & $E 426$ & $709 B-2$ & VII-33 & 362.93 & 36.33 & 33.50 & $1 p c$ & \\
\hline & & & E185 & $714 \mathrm{~B}-1$ & VII-34 & 325.78 & 33.07 & 30.46 & $7 p o s$ & \\
\hline & & & E335 & $693 \mathrm{~B}-1$ & arctive & 236.39 & 24.82 & 23.12 & 8 pas & \\
\hline & & & E564 & $703 A-3$ & archive & 265.05 & 28.25 & 26.32 & 10 pos & \\
\hline & & & E144 & $7100-1$ & $V-5$ & 254.79 & 25.96 & 23.88 & $20 \mathrm{pcs}+6 \mathrm{wa}$ & fers \\
\hline & & & E416 & $7080-4$ & IV-8 & 291.17 & 29.52 & 27.29 & $23 p a s+3 w$ & fers \\
\hline
\end{tabular}




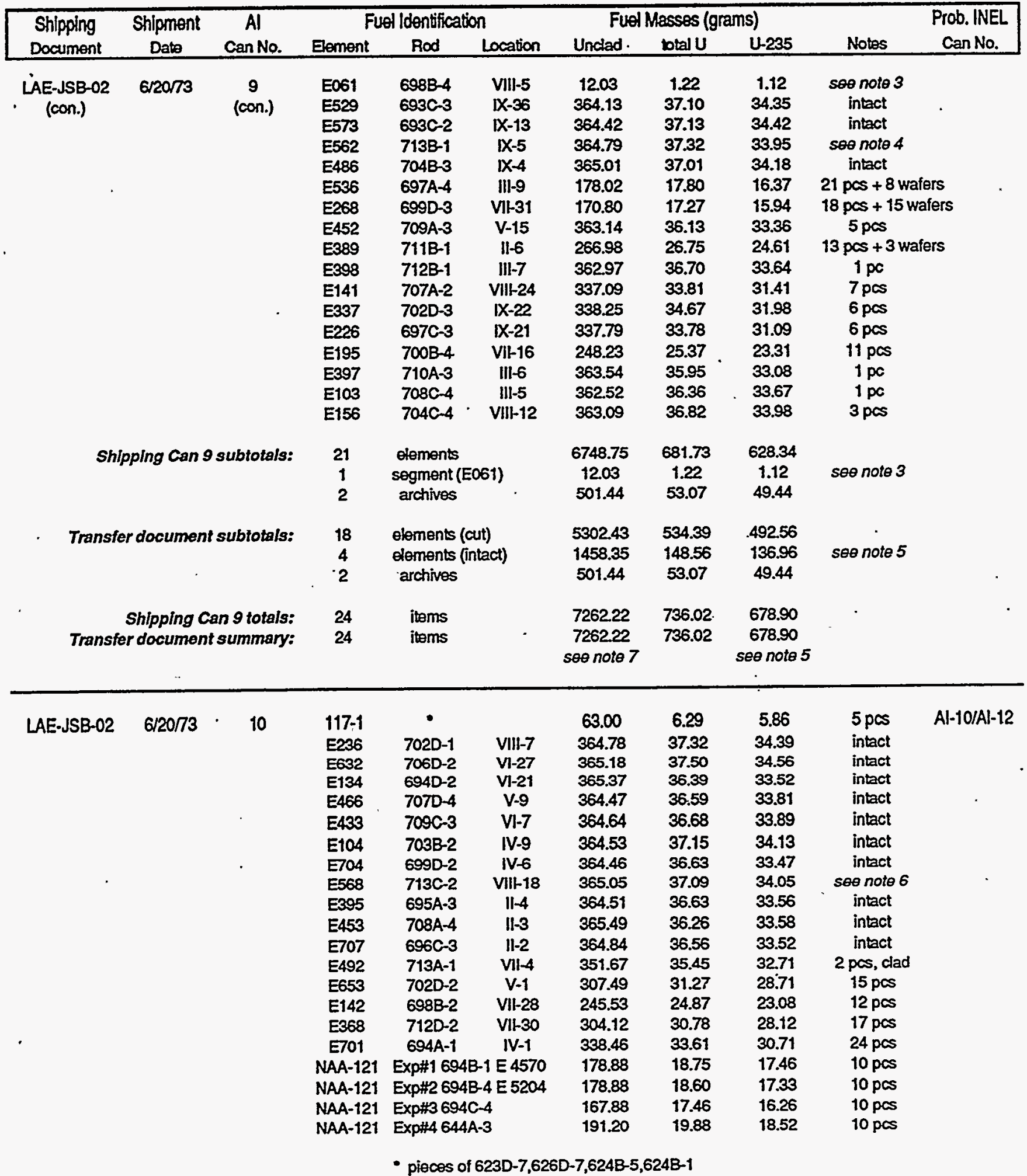




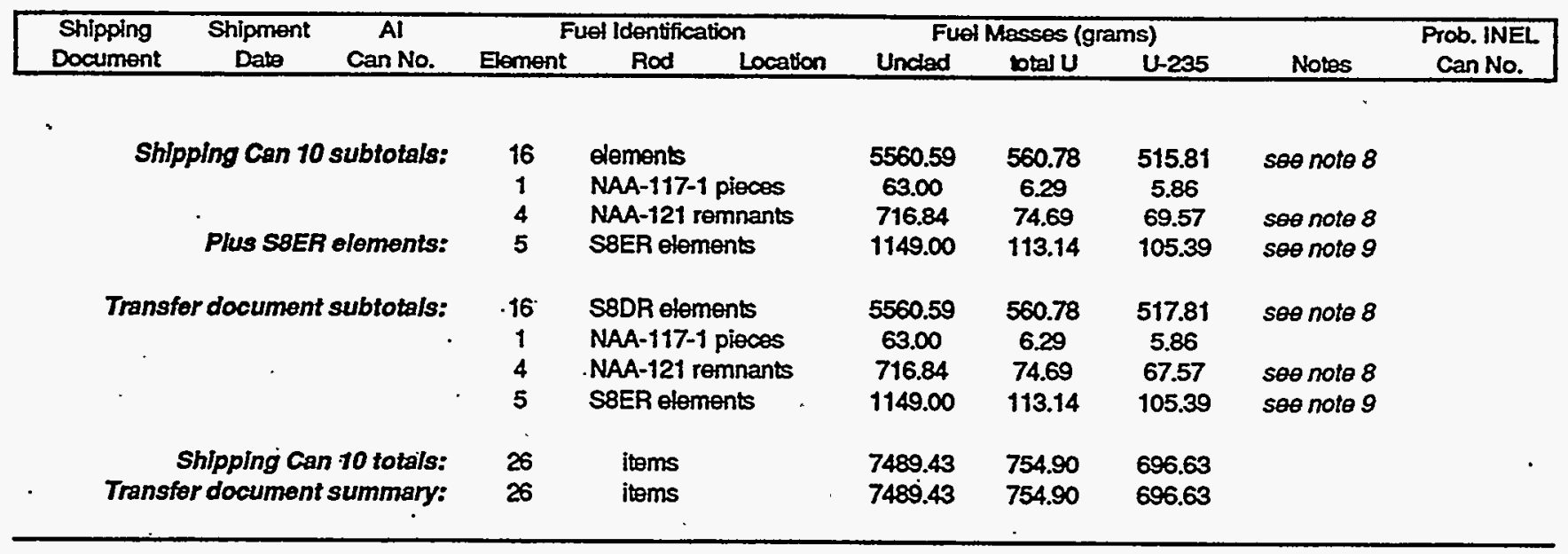

\section{LAEJSB-02 Shipment Totals:}

$\begin{array}{rclccc}\text { S8DR-irradiated: } & 77 & \text { elements, segments } & .26119 .9 & 2641.58 & 2435.33 \\ \text { S8DR archives: } & 2 & \text { archives } & 501.44 & 53.07 & 49.44 \\ \text { Irradlated In-plle specimens: } & 6 & \text { in-pile segments } & 791.87 & 82.2 & 75.43 \\ \text { S8ER elements: } & 5 & \text {. elements } & 1149.00 & 113.14 & 105.39\end{array}$

\begin{tabular}{|c|c|c|c|c|c|}
\hline $\begin{array}{r}\text { LAE-JSB-02 shipment totals: } \\
\text { Transfer document: }\end{array}$ & $\begin{array}{l}90 \\
90\end{array}$ & $\begin{array}{l}\text { items } \\
\text { items }\end{array}$ & $\begin{array}{l}.28562 .21 \\
28562.27\end{array}$ & $\begin{array}{l}2889.99 \\
2889.99\end{array}$ & $\begin{array}{l}2665.59 \\
2665.59\end{array}$ \\
\hline
\end{tabular}

\begin{tabular}{lcccccc}
\hline & & & & & \\
\hline & & & & & & \\
S8DR reactor totals:. &. & 211 & irradiated elements & 75005.89 & 7592.7 & 6999.03 \\
& 2 & archived elements & 501.44 & 53.07 & 49.44
\end{tabular}

References: - Data transcribed from archived copies of original shipping records

.. Mass sums compared with S8DR transfer document summary shets for the two shipments Fuel element and fiel rod identifications compared with QA traceability document Do68 (AL-AEC-TDR-12702, 3/21/68) Disassembly status of elements in Cans 7-10 from North American Rockwell Internal Letters Mc71a, Sc73

Notes: $\quad \therefore$. Element E316 in Al Can No. 3 was in core location II-5; location VIII-18 listed in shipping document is incorrect.

2. Unciad fuel total mass for Al Can No. 7 is $0.06 \mathrm{~g}$ lower for the spreadsheet sum than the transfer document sum. This could be an addition error in the transfer document, a transcription error in a transfer document sum (recording $5385.36 \mathrm{~g}$ for class 38 instead of $5385.30 \mathrm{~g}$ ), or an element mass error. This difference is also the 0.06-g difference in the spreadsheet vs. transfer document total masses for shipment LAE-JSB-02.

3. One small segment of E061 was shipped in Al Car: No. 9; most (in 2 pos) was in Al Can No. 8.

4. Shipping records for Al Can No. 9 incorrecty list E562 core location as IV-5; IX-5 is correct. Element shipped intact.

5. Transfer document summary for Al Can No. $9 \mathrm{Ux}$ total for 4 intact elements has a typo: should be $136.90 \mathrm{~g}$ instead of $136.96 \mathrm{~g}$. Transfer document sum $(678.90 \mathrm{~g})$ is correct.

6. Element E568 in Al Can No. 10 was in core location VIII-18; location II-5 listed in shipping document and Hot Cell records is incorrect. Element shippod intact.

7. Transfer document summary for Al Can No. 10 lists Not UZrH2 as $1262.22 \mathrm{~g}$ instead of $7262.22 \mathrm{~g}$, a typo.

8. Transfer document summary has two offsetting 2-g errors: total for 16 S8DR elements should be $517.81 \mathrm{~g}$, and total for NAA-121 remnants should be $69.57 \mathrm{~g}$.

9. S8ER fuel elements are documented in S8ER Shipping Record Summary spreadsheet. 


\section{SHIELD TEST FACILITY (STF)}

Initial criticality

. Date of shutdown:

Thermal power:

Operating location:
October 9, 1962 (To62)

July 1964 (then rebuilt as STIR with MTR-type fuel elements) $50 \mathrm{kWt}$

SSFL Building 028

\subsection{STF GENERAL DESCRIPTION}

The Shield Test Facility (STF) was a pool-type reactor used primarily to generate radiation fields for shielding tests of SNAP reactor components. It initially had a 50-kWt core fueled with SNAP reactor fuel elements, and was operated at this power level between 1961 and 1964. In 1964 the reactor was modified to raise the power rating to $1000 \mathrm{kWt}$, by installing a new core type fueled with Materials Test Reactor (MTR) type fuel elements. This rebuilt configuration was renamed the Shield Test and Irradiation Reactor (STIR), which operated between 1964 and 1972. The fuel elements of interest for the present investigation are those from the original STF 50-kWt SNAP-type core, which had hydrided zirconiumuranium fuel rods. The uranium was $7 \mathrm{wt} . \%$, with a nominal ${ }^{235} \mathrm{U}$ content of $93^{+}$wt.\%.

There were two core loadings using SNAP fuel (To62). The initial loading consisted of 60 fuel rods. It was-not effective for driving the facility's fission plate, the purpose for which the reactor was constructed, and thus the reactor core loading was reconfigured. The second loading consisted of 56 fuel rods and several BeO reflector elements. This is the INEL-stored SNAP-reactor fuel for which the least information was obtained. However, since the facility was fueled with reject SER fuel rods, a description of the fuel rods may be taken from the SER documentation.

An overview description of the facility is given in 0191, and a pre-operation.description in Jo61.

\subsection{STF REACTOR AND FUEL DENTIFICATION}

Reactor: $\quad$ Shield Test Facility (STF)

Also identified as: $\quad$ Shield Test Reactor (STR)

SNAP Shield Test Experiment (STE)

Core fuel Identification: STF (same as reactor name)

Reactor designer, builder, operator: Atomics International

Reactor owner: Atomic Energy Commission (now DOE)

Fuel designer, builder: Atomics Intemational

Fuel owner: Atomic Energy Commission (now DOE)

\subsection{STF DESIGN REACTOR PHYSICS AND CORE. DESCRIPTION}

To62 There were two SNAP-type core loadings. The first core used 61 reject SER fuel rods, clad in Type 6061 aluminum alloy. No hydrogen barrier was used. The second core loading used 56 of the reject SER fuel rods, and included several $\mathrm{BeO}$ reflector elements. 
Jo61 Pre-operation reactor physics parameters (Table III), for 45-element core

To61 Pre-operation reactor physics parameters (Table VI), for 45-element core

Fuel elements/assemblies:

To62 61 in first core loading, 56 in second

Design neutron flux:

Design neutron energy:

Core map and element locator:

To62 Initial core map (Fig. 1, 60 fuel rods) and second core map (Fig. 2, 56 fuel rods)

(Note: we have not correlated the two core maps to verify that the same fuel elements were used in both core loadings.)

\subsection{STF FUEL FABRICATION INFORMATION}

Fuel specifications and drawings:

J061 Fuel element drawing and some composition information (B.1.a)

To61 Brief description of fuel element chemistry and design

Fuel fabrication and quality control:

Fuel cladding, inner coatings, and other non-fuel materials:

Cladding was Type 6061 aluminum alloy; with no inner coating

Potential fuel chemical reactions:

Potential RCRA-regulated materials:

Quantities of materials:

See shipping spreadsheets (fuel rods, $U,{ }^{235} \mathrm{U}$ )

Fuel assembly identification methods:

\subsection{STF OPERATIONAL HISTORY}

Core Operating History:

Core neutron flux profile:

Operation abnormalities:

Core shut-down date:

Core discharge date:

\subsection{STF POST-IRRADIATION PROPERTIES AND EXAMINATION}

(There was no post-irradiation examination of these fuel elements.)

Visual observations:

Dimensions:

Metallurgical states of materials:

Cladding defects:

Corrosion or chemical contamination: 


\section{Hydrogen effects:}

Burnup:

Fission products:

Transuranics:

Activation products:

Decay heat generation:

Radiation level decay curves:

Alpha contamination:

(not relevant for the declad fuels)

\subsection{STF ON-SITE STORAGE HISTORY}

SNAP fuel elements were stored in air at the RMDF in dry storage vaults in preparation for shipment to INEL. There were no wet-storage facilities available at Atomics Intemational. No detailed storage history documentation is available.

\subsection{STF SHIPPING RECORDS}

The STF fuel shipping records for shipments to INEL were reviewed in detail. The original records are difficult to read, and were transcribed onto the STF spreadsheet that is reproduced at the end of this section. The spreadsheet lists the fuel rod (unclad), total uranium, and ${ }^{235} U$ masses for each fuel element, 'plus the shipping document number, shipment date, Atomics International can number, and probable INEL. aluminum can number. The latter is base on document copies received from INEL as part of the current review activity. 61 STF fuel elements were shipped to INEL.

. The mass totals shown on the spreadsheet were calculated from the individual recorded fuel element data: They were compared with a Shield Test Fuel Data mass sheet dated 7/27/64 and filed with the shipping records. This comparison shows a slight discrepancy for AI Can No. 3, where the data sheet-lists the total uranium mass as $275 \mathrm{~g}$, instead of $269 \mathrm{~g}$ as obtained from the shipping records (with a corresponding total : uranium for STF of $2883 \mathrm{~g}$ instead of $2877 \mathrm{~g}$ ). The fuel data sheet is probably in error, but we cannot verify.

\subsection{STF REFERENCES}

Jo61* R. P. Johnson, "SNAP Shield Test Experiment Operations Manual," Atomics International Report NAA-SR-5897 (June 1961) (196 pages)

0191 R. D. Oldenkamp and J.. C. Mills, "Nuclear Operations at Rockwell's Santa Susana Field Laboratory - A Factual Perspective," Rockwell International, Rocketdyne Division Supporting Document N001ER000017 (September 1991) (95 pages)

To61* R. L. Tomlinson, "SNAP Shield Test Experiment Final Hazards Summary," Atomics International Report NAA-SR-5896 (March 1961) (173 pages)

To62* R. L. Tomlinson, R. P. Johnson, and S. G. Wogulis, "SNAP Shield Test Experiment Reactor Physics Tests," Atomics International Report NAA-SR-7368 (July 1962) 


\begin{tabular}{|c|c|c|c|c|c|c|c|c|c|c|}
\hline \multirow{2}{*}{$\begin{array}{l}\text { Shipping } \\
\text { Document }\end{array}$} & \multirow{2}{*}{$\begin{array}{c}\text { Shipment } \\
\text { Date }\end{array}$} & \multirow{2}{*}{$\begin{array}{c}\text { Al } \\
\text { Can No. }\end{array}$} & \multicolumn{3}{|c|}{ Fuel Identification } & \multicolumn{3}{|c|}{ Fuel Masses (grams) } & \multicolumn{2}{|r|}{ Prob. INEL } \\
\hline & & & Element & Rod & Location & Unclad & total U & U-235 & Notes & Can No. \\
\hline \multirow[t]{7}{*}{ CAE-JZA-21 } & $5 / 20 / 66$ & 3 & $A-51$ & & & 648 & 45 & 42 & & 7 \\
\hline & & & A-31 & & & 644 & 45 & 42 & & \\
\hline & & & $A-19$ & & & 641 & 45 & 42 & & \\
\hline & & & A-52 & & & 644 . & 44 & 41 & & \\
\hline & & & $A-45$ & & . & 649 & 45 & 42 & & \\
\hline & & & A-37 & & & 647 & 45 & 42 & & \\
\hline & \multicolumn{2}{|c|}{ Shipment totals: } & 6 & elements & & 3873 & 269 & 251 & & \\
\hline \multirow[t]{7}{*}{ CAE-JZA-22 } & $5 / 27 / 66$ & 1 & A-1T & & & 644 & 44 & 41 & & 7 \\
\hline & & & $A-16$ & & & 672 & 47 & 44 & & \\
\hline & & & A-2T & & & 644 & 44 & 41 & & \\
\hline & & & $A-7$ & & & 647 & 45 & 42 & & \\
\hline & & & A-13 & 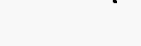 & & 651 & 46 & 43 & & \\
\hline & & & A-18 & & & 615 & 43 & 40 & & \\
\hline & \multicolumn{2}{|c|}{ Shipment totals: } & 6 & elements & & 3873 & 269 & 251 & & \\
\hline \multirow[t]{7}{*}{ CAE-JZA-23 } & $6 / 4 / 66$ & 5 & A.50 & & & 651 & 45 & 42 & & 8 \\
\hline & & & A-24 & & & 644 & 45 & 42 & & \\
\hline & & & A-23 & & & 644 & 45 & 42 & & \\
\hline & & & A-30 & & & 646 & 45 & 42 & & \\
\hline & & & $\cdot A-8$ & & & 615 & 43 & 40 & & \\
\hline & & & $A-17$ & & & 648 & 45 & 42 & & \\
\hline & \multicolumn{2}{|c|}{ Shipment totals: } & 6 . & elements & & 3848 & 268 & 250 & . & \\
\hline \multirow[t]{7}{*}{ CAE-JZA-24C } & $6 / 766$ & 4 & $c-1$ & $\cdot$ & & 699 & 69 & 64 & & 8 \\
\hline & & & B-3 & & & 629. & 43 & 40 & & \\
\hline & & & A-38 & & & 649 & 45 & 42 & & \\
\hline & & & A-9 & & & 644 & 45 & 42 & & \\
\hline & & & A-21 & & & 647 & 45 & 42 & & \\
\hline & & & $A-10$ & - & & 648 & 45 & 42 & & \\
\hline & \multicolumn{2}{|c|}{ Shipment totals: } & 6 & elements & & 3916 & 292 & 272 & & \\
\hline \multirow[t]{7}{*}{ CAE-JZA-25 } & $6 / 10 / 66$ & 6 & A-3T. & & & 639 & 44 & 41 & & 8 \\
\hline & & & B-5 & & & 618 & 42 & 39 & & \\
\hline & & & $A-36$ & & & 678 & 47 & 44 & & \\
\hline & & & A-5 & & & 643 & 45 & 42 & & \\
\hline & & & $A-41$ & & & 640 & 45 & 42 & & \\
\hline & & & $c-5$ & & & 704 & 70 & 65 & & \\
\hline & \multicolumn{2}{|c|}{ Shipment totals: } & 6 & elements & & 3922 & 293 & 273 & & \\
\hline \multirow[t]{7}{*}{ CAE-JZA-26 } & $6 / 14 / 66$ & 2 & A-20 & & & 650 & 46 & 43 & & 7 \\
\hline & & & A-33 & & & 645 & 45 & 42 & & \\
\hline & & & A-34 & & & 651 & 46 & 43 & & \\
\hline & & & A-35 & & & 652 & 46 & 43 & & \\
\hline & & & A-39 & & & 649 & 45 & 42 & & \\
\hline & & & $A-44$ & & & 648 & 45 & 42 & & \\
\hline & Shipt & nent totals: & 6 & elements & & $3895^{\circ}$ & 273 & 255 & & \\
\hline
\end{tabular}




\begin{tabular}{|c|c|c|c|c|c|c|c|c|c|c|}
\hline \multirow{2}{*}{$\begin{array}{l}\text { Shipping } \\
\text { Document }\end{array}$} & \multirow{2}{*}{$\begin{array}{c}\text { Shipment } \\
\text { Date }\end{array}$} & \multirow{2}{*}{$\begin{array}{c}\text { Al } \\
\text { Can No. }\end{array}$} & \multicolumn{3}{|c|}{ Fuel Identification } & \multicolumn{3}{|c|}{ Fud Masses (grams) } & & \multirow{2}{*}{$\begin{array}{l}\text { Prob. INEL } \\
\text { Can No. }\end{array}$} \\
\hline & & & Eement & Rod & Location & Unclad & btal U & U-235 & Notes & \\
\hline CุAE-JZA-27 & $6 / 16 / 66$ & 8 & $A-15$ & & & 648 & 45 & 42 & & 9 \\
\hline \multirow[t]{6}{*}{ 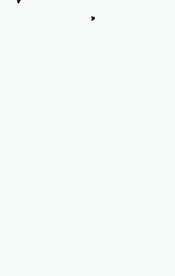 } & & & B-4 & & & 635 & 43 & 40 & & \\
\hline & & & $A-48$ & & & 669 & 47 & 44 & & \\
\hline & & & A-26 & & & $640^{\circ}$ & 45 & 42 & & \\
\hline & & & $A-11$ & & & 648 & 45 & 42 & & \\
\hline & & & $c-4$ & & & 762 & 75 & 70 & & \\
\hline & \multicolumn{2}{|c|}{ Shipment totals: } & 6 & elements & & 4002 & 300 & 280 & & \\
\hline \multirow[t]{7}{*}{ CAE-JZA-28 } & $6 / 20 / 66$ & 7 & $c-2$ & & & 702 & 70 & 65 & & 9 \\
\hline & & & A-32 & & & 648 & 45 & 42 & & \\
\hline & & & A-27 & & & 652 & 46 & 43 & & \\
\hline & & & $A-47$ & & c & 644 & 45 & 42 & & \\
\hline & & & $A-40$ & & & 641 & 45 & 42 & & \\
\hline & & & A-12 & & & 649 & 45 & 42 & & \\
\hline & \multicolumn{2}{|c|}{ Shipment totals: } & 6 & elements & & 3936 & 296 & 276 & & \\
\hline \multirow[t]{7}{*}{ CAE-JZA-29 } & $6 / 22 / 66$ & 9 & $A-46$ & & & 645 & 45 & 42 & & 10 \\
\hline & & & A-25 & & & 646 & 45 & 42 & & \\
\hline & & & $A-4$ & & & 669 & 47 & 44 & & \\
\hline & & & B-2 & & & 643 & 44 & 41 & & \\
\hline & & & $A-42$ & & & 644 & 45 & 42 & & \\
\hline & & & C-3 & & & 708 & 70 & 65 & & \\
\hline & \multicolumn{2}{|c|}{ ShJpment totols: } & 6 & elements & & 3955 & 296 & 276 & & \\
\hline \multirow[t]{5}{*}{ CAE-JZA-30 } & $6 / 24 / 66$ & 10 & A.22 & & & 645 & 45 & 42 & & 10 \\
\hline & & & A-28 & & & 643 & 45 & 42 & & \\
\hline & & & $A-43$ & & & 647 & 45 & $42^{\circ}$ & & \\
\hline & & & A-14 & & & 644 & 45 & 42 & & \\
\hline & & & A.29 & & & 645 & 45 & 42 & & \\
\hline \multirow[t]{2}{*}{$\cdot$} & & & $A-6$ & & & 679 & 48 & 45 & & \\
\hline & \multicolumn{2}{|c|}{ Shipment totals: } & 6 & elements & & 3903 & 273 & 255 & & \\
\hline \multirow[t]{2}{*}{ CAE-JZA-31 } & $6 / 28 / 66$ & 11 & $A-49$ & & & 685 & 48 & 45 & & 10 \\
\hline & \multicolumn{2}{|c|}{ Shipment totals: } & 1 & elements & & 685 & 48 & 45 & & \\
\hline
\end{tabular}

Reference: Data transcribed from archived copies of original shipping records Comparison made with Shield Test Fuel Data sheet dated 7/27/64

Notes: $\quad 61$ fuel elements received by INEL per BUC-41-66A

Five fuel elements $(C-1,2,3,4,5)$ have higher uranium concentrations (10 wt. \% instead of $7 \mathrm{wt} \%)$

For Al Can No. 3, original shield test fuel data sheet lists total $U$ mass as $275 \mathrm{~g}$ (instead of $269 \mathrm{~g}$ ) and total $\mathrm{U}$ for STF as $2883 \mathrm{~g}$ (instead of $2877 \mathrm{~g}$ ). The individual rods total $269 \mathrm{~g}$ (shown on spreadsheot). The fuel data sheet is probably in error, but cannot verify. 
IN-PILE FUEL EXPERIMENTS 


\section{NAA-82-1 IN-PILE FUEL EXPERIMENT}

Placed in reactor:

- Removed from reactor:

Thermal power:

Irradiation location:
April 10, 1964 (Kr66)

August 16, 1965 (Bu67)

Not Available

NRTS (INEL) MTR

\subsection{NAA-82 GENERAL DESCRIPTION}

The objective of the NAA-82-1 experiment was to determine the irradiation behavior of a prototype zirconium-uranium hydride SNAP 2 fuel element at peak temperature and burnup conditions for $125 \mathrm{kWt}$ operation of a SNAP 2 core $(\mathrm{K} r 66)$. The single fuel element was irradiated in the Materials Test Reactor (MTR) for 8760 hours at an estimated peak fuel temperature of $1490^{\circ} \mathrm{F}$ to a burnup of 0.09 metalatom \%.

\subsection{NAA-82 FUEL IDENTIFICATION}

Reactor type: SNAP 2

Fuel identification: NAA-82

Fuel Specimen Identification: Single fuel element E2004 (Kr66)

. Experiment designer, builder: Atomics International

Reactor owner: Atomic Energy Commission (now DOE)

Fuel designer, builder: Atomics Intemational

Fuel owner: Atomic Energy Commission (now DOE)

\subsection{NAA-82 REACTOR EXPERIMENT DESCRIPTION}

Bu67 Irradiation capsule schematic (Fig. 2)

\section{Experiment design parameters:}

Design neutron flux:

Bu67 MTR calculated position-dependent relative thermal and fast fluxes (Fig. 8)

Design neutron energy:

Core element locator:

Bu67 MTR cross section mockup for nuclear analysis with capsule location noted (Fig. 7)

\subsection{NAA-82 FUEL FABRICATION INFORMATION}

Fuel specifications and drawings:

Kr66 Experiment assembly drawing (Fig. 1)

Bu67 Fuel rod and fuel element assembly schematic drawings (Fig. 1) 
Fuel fabrication and quality control:

Sc65 Reference SNAP 2 fuel element

Kr66 Fuel element dimensions (page 5); fuel rod information (page 6), including dimensions, $\mathrm{U}, \mathrm{Zr}, \mathrm{H}, \mathrm{C}$, and total impurity content, density, $\mathrm{N}_{\mathrm{H}}$, weight, ${ }^{235} \mathrm{U}$ weight

Bu67 Fuel rod $\mathrm{Zr}-10 \mathrm{wt} . \% \mathrm{U}$ alloy; fuel element and fuel rod data in Table 1

Fuel cladding, inner coatings, and other non-fuel materials:

Kr66 Hastelloy-N cladding and AI-8763D hydrogen barrier coating (page 5)

Bu67 Chemical composition of Hastelloy-N cladding (Table 2); NaK surrounded fuel element

Potential fuel chemical reactions:

Potential RCRA-regulated materials:

Quantities of materials:

See shipping spreadsheets (fuel rods, $\mathrm{U},{ }^{235} \mathrm{U}$ )

Fuel assembly identification methods:

Kr66 Identification markings on lower end of fuel rod shown in Fig. 6b

Bu67 Identification markings on lower end of fuel rod shown in Fig. 23a

\subsection{NAA-82 IRRADIATION HISTORY}

Experiment Operating History:

Sc65 Irradiated to $125 \mathrm{kWt}$ SNAP 2 conditions

Kr66 Irradiated for 8,760 hours at peak fuel temperature of $1490^{\circ} \mathrm{F}$

Bu67 Irradiated for 23 reactor cycles in the MTR, starting April 9, 1964 (cycle 207) and discharged August 16, 1965 (end of cycle 229); design peak cladding maintained at 1300 $\pm 15^{\circ} \mathrm{F}$ for $93.4 \%(8479 \mathrm{~h})$ of full-power operation

Neutron flux profile:

Operation abnormalities:

\subsection{NAA-82 POST-IRRADIATION PROPERTIES AND EXAMINATION}

Sc65 Diagram of planned sectioning for future post-irradiation examination

Kr66 Fuel rod sectioning diagram for post-irradiation examination (Fig. 9)

Bu67 Fuel rod sampling plan (Fig. 25)

Visual observations:

Sc65 Element exterior appeared to be in excellent condition with no observable defects

Kr66 Photographs of fuel element (after NaK removal; Figs. 4A, 4B), fuel rod (Fig. 5, 6), inside surface of cladding (Fig. 7,8)

Bu67 Photograph of fuel element (Fig. 20, no defects observed), fuel rod (Fig. 22, no damage)

Dimensions:

Kr66 Post-irradiation fuel element diameters (Table I), fuel element length measurements (page 15), fuel rod diameters (Table III), fuel rod length measurements (page 24), density measurements (Table VIII and Appendix III), fuel element dimensions (Appendix I), fuel rod dimensions (Appendix II) 
Bi67 Percent volume change of 3 samples (Table 6); diametrical fuel growth (Fig. 3, 5-11); volumetric fuel growth (Fig. 13, 14)

Bu67 Fuel element diameters (Table 8) and length measurements; fuel rod diameters (Table 10), densities (Table 11), and dimensional changes (Table 13)

"Metallurgical states of materials:

Kr66 Photomicrographs of fuel alloy (Fig. 15), and cladding plus ceramic coating (Fig. 16) and metallography analysis (Appendix IV)

Bu67 Photomicrographs of cladding (Fig. 24) and unirradiated plus irradiated fuel rod material (Fig. 29)

Cladding defects:

Kr66 No cladding defects found

Corrosion or chemical contamination:

Kr66 Photograph of ceramic adhering to fuel rod (Fig. 6b)

Bu67 Some transfer of ceramic coating from inside of end caps to ends of fuel rod

Hydrogen effects:

Kr66 - Hydrogen analysis results (Table IX)

- Bi67 Initial and final hydrogen content for 8 samples (Table 6); H/Zr ratios (Fig. 20)

Bu67 Fuel hydrogen analysis (Table 12) and distribution (Fig. 26), and variation of zirconium hydride density with hydrogen content (Fig. 27)

Burnup:

Sc65 0.08 metal-atom \% bumup at peak fuel temperature in excess of $1500^{\circ} \mathrm{F}$

Kr66 Calculated burnup of 0.08 metal-atom \%; mass spectrographic bumup results (based on analyses at Phillips Petroleum), giving an average of 0.09 metal-atom \%, and compares with calculated value of $0.08 \mathrm{~m}-\mathrm{a} \%$ (Table VII)

Bi67 Bumup for 3 samples (Täble 6); diametric fuel growth vs. burnup (Fig. 3, 6)

Bu67 Gamma scans \& autoradiographs of bumup data (Fig. 30); fuel bumup analysis (Table. 14)

Fission products:

Kr66 Fission gas release data (Table II); Gamma scan data (Tables V, VI and Fig. 10, 1.1)

Bu67 Fission gas release measurements

Transuranics:

Activation products:

Decay heat generation:

Radiation level decay curves:

Alpha contamination:

(not relevant for the declad fuels)

\subsection{NAA-82 ON-SITE STORAGE HISTORY}

The NAA 82-1 experiment was received at the Atomics International Hot Laboratory (AIHL) on September 28, 1965 (Kr66). It was shipped to AI full of NaK, and declad in the AIHL in an inert (nitrogen) atmosphere to prevent NaK fires. The fuel element was stored at the AIHL while post-irradiation examinations were proceeding, and then shipped to AI's Radioactive Materials 
Disposal Facility (RMDF) in a shipping cask for temporary storage before shipment to. INEL. It was always stored in air at both the RMDF and the AIHL.

\section{; 12.8 NAA-82 SHIPPING RECORDS}

The NAA-82-1 fuel rod material (from one irradiation capsule) shipped to INEL is listed in the S8ER Shipping Record Summary, where it is included under shipment LAE-JWA-26. .

\subsection{REFERENCES}

. Bi67* - K. R. Bimey, "An Empirical Study of SNAP Reactor Fuel Irradiation Behavior," Atomics International Report NAA-SR-12284 (August 1967)

Bu67* J. S. Buck, W. E. Krupp, and T. A. Park, "Irradiation Performance of a Full-Scale Prototype SNAP.2 Reactor Fuel Element," Atomics Intemational Report NAA-SR-12030 (August 1967) (82 pages)

Kr66 W.E. Krupp, "Post-Irradiation Examination of the NAA 82-1 Experiment," Atomics International Technical Data Record NAA-SR-MEMO-11891 (March 1966) (51 pages).

Sc65 A. R. Schmitt, "Post-Irradiation Examination of NAA-82-1," Atomics International Internal-Letter dated 27 October 1965 (4 pages) 


\section{NAA-115-2 IN-PILE FUEL EXPERIMENT}

Irradiation start date:

- Irradiation end date:

Thermal power:

Irradiation location:
Not available

Not available

Not available

Hanford K-East Reactor

\subsection{NAA-115 GENERAL DESCRIPTION}

NAA-115-2 was one of three similar irradiation experiments (NAA-115-1, NAA-115-2, and NAA-117-1) that were statistically designed to test and evaluate sub-length SNAP 8 fuel elements. NAA-115-1 and NAA-115-2 were nearly identical in design with the exception that NAA-115-2 contained a newer hydrogen.barrier (SCB-1) which .was to be used for S8DR fuel elements, and the closure cup plug component was changed to the S8DR design (Fo67b). Both NAA-115 experiments contained 12 sublength fuel elements with target burmups ranging from 0.3 to 0.4 metal-atom \%. The NAA-115-2 elements (for which fuel material is in storage at INEL). were formed into six separate experimental capsules which were connected in series to form a 12-foot-long test assembly.

Additional information is available for the separate experiment NAA-115-1, including a report compilation of NAA-115-1 photographs. A summary of several of the in-pile experiments is provided in Bi67.

\subsection{NAA-115 FUEL IDENTIFICATION}

Reactor type: S8DR

Fuel identification: NAA-115

Fuel Specimen Identification:

-Fo67b Sublength fuel elements (Fig. 2); identification of fuel elements in each capsule (Fig. 1); · fuel elements identified as. IS 21 through IS 32

. Fo68 Fuel element identification/fuel rod number identification (with compositions)

Experiment designer, builder: Atomics International

Reactor owner: Atomic Energy Commission (now DOE)

Fuel designer, builder: Atomics Intemational

Fuel owner: Atomic Energy Commission (now DOE)

\subsection{NAA-115 REACTOR EXPERIMENT DESCRIPTION}

Experiment design parameters:

Fo67b 12 test fuel elements, contained in 6 capsules (Fig. 1)

Fo68 Reports intentionally do not disclose information that might disclose Hanford production information

Design neutron flux:

Design neutron energy: 
Core element locator:

Fo67b 12 test fuel elements incorporated-in experiment

\subsection{NAA-115 FUEL FABRICATION INFORMATION}

Fuel specifications and drawings:

Fo68 . Engineering drawing of a four-fuel-element capsule (Fig. 8); engineering drawing of a single-fuel-element capsule (Fig. 9)

Fuel fabrication and quality control:

Fo67b Schematic cross section of a typical fuel element (Fig. 1); schematics of instrumented and uninstrumented fuel elements (Fig. 2); fuel rod composition $\left(\mathrm{U}, \mathrm{ZrC}, \mathrm{H}, \mathrm{N}_{\mathrm{H}}\right.$, density; Table D; fuel rod dimensions (O.D., length; Table II)

Fo68 -S8DR sublength fuel element; schematic comparing fuel element with full length S8DR fuel element design (Fig. 3); 15 were fabricated and 12 irradiated, where the 3 unirradiated elements were used in the hot cell to develop disassembly procedures. (This . suggests that some unirradiated pieces might also have been shipped.) Design materials and dimensions (Table 1); chemical composition of hydrided.Zr-U alloy material (Table 6 ); photographs of pre-irradiation capsule parts, including fuel-elements and fuel rods (Appendix 1)

Fuel cladding, inner coatings, and other non-fuel materials:

Fo67b Cladding was Hastelloy-N.(Fig. 2); coating was SCB-1

Fo68 Chemical composition and mechanical properties of Hastelloy- $\mathrm{N}$ used in the experiment (Tables -2; 3); composition of SCB-1 hydrogen barrier (Table 4); chromizing and hydrogen barrier coating thicknesses (Table 5)

Potential fuel chemical reactions:

Potential RCRA-regulated materials:

Quantities of materials:

See shipping spreadsheets (fuel rods, $U,{ }^{235} \mathrm{U}$ )

Fuel assembly identification methods:

Fo67b · Photograph showing fuel element ID scribed on end (Fig. 7)

\subsection{NAA-115 IRRADIATION HISTORY}

Experiment Operating History:

Fo67b Approximate 10,000-hour irradiation time; cladding temperatures varied from $970^{\circ} \mathrm{F}$ to $1335^{\circ} \mathrm{F}$, with calculated fuel centerline temperatures ranging from $1290^{\circ} \mathrm{F}$ to $1620^{\circ} \mathrm{F}$

Fo68 Detailed cladding thermal history data (Table 16)

Neutron flux profile:

Operation abnormalities:

Fo67b Experiment was discharged from the Hanford K-East reactor after it experienced a full reactor scram at design temperatures. It was cooled from design temperatures $\left(1300^{\circ} \mathrm{F}\right.$ to $1600^{\circ} \mathrm{F}$ fuel centerline) to coolant temperature $\left(-250^{\circ} \mathrm{F}\right)$ in 80 seconds. 


\subsection{NAA-115 POST-IRRADIATION PROPERTIES AND EXAMINATION}

Fo67b Detailed post-irradiation examination report

Fo68 Summary and detailed analysis of information from Fo67b, plus additional design and instrumentation (including dosimetry) details; comparisons with NAA-115-1 and NAA-117-1 experiment results; post-irradiation photographs of each specimen with data summaries, including locations from which samples were taken (Appendix II)

Visual observations:

Fo67a A large volume of post-irradiation photographs

F067b Visual and photographic results of capsules and the fuel elements they contained; visual and photographic results of the fuel rods after disassembly

Fo68 Representative photographs of post-irradiation fuel elements and fuel rods

\section{Dimensions:}

Fo67b Cladding \& fuel rod dimensional measurements, fuel rod densities

Metallurgical states of materials:

Fo67b Photomicrographs of the fuel and cladding (including color photomicrographs, and identification of fuel material phases); fuel and cladding hardness measurements; cladding tensile strengths

Fo68 Photomicrographs and hardness data for fuel and cladding

\section{Cladding defects:}

Fo67b Photographs of cladding cracks in fuel elements IS 22, 29, 30 (Fig. 4)

Corrosion or chemical contamination:

Fo67b .Photograph of coating adhering to fuel (Fig. 13)

Hydrogen effects:

Fo67b Hydrogen analysis

\section{Burnup:}

Fo67b Calculated burnup based on thermal history 0.33 to 0.37 metal-atom \%; burnup analysis provided; fuel rod autoradiograph profiles for burnup analysis

Fission products:

Fo67b Fission gas analysis

Transuranics:

Activation products:

Fo67b Fuel element gamma scan results

Decay heat generation:

Radiation level decay curves:

Alpha contamination:

(not relevant for the declad fuel) 


\subsection{NAA-115 ON-SITE STORAGE HISTORY}

The NAA-115-2 tèst assembly was sectioned at Hanford and the six capsules were shipped to the Atomics International Hot Laboratory (AIHL). They were received at the AIHL in two different cask shipments in December 1966 (Fo67b). The fuel materials were stored at the AIHL while post-irradiation examinations were proceeding, and then shipped to AI's Radioactive Materials.Disposal Facility (RMDF) for temporary storage before shipment to INEL. They were always stored in air at both the RMDF and the AIfIL.

\subsection{NAA-115 SHIPPING RECORDS}

The NAA-115-2 fuel rod material (from two irradiation capsules) shipped to INEL is listed in the S8ER . Shipping Record Summary, where it is included under shipment LAE-JWA-26.

\subsection{REFERENCES}

Bi67* K. R. Bimey, "Ain Empirical Study of SNAP Reactor Fuel Irradiation Behavior," Atomics International Report NAA-SR-12284 (August 1967)

Fo67a.R. E. Forrester, "Post-Irradiation Photographs for the NAA. 115-2 Experiment,". Atomics . Intemational Technical Data Record NAA-SR-MEMO-12430 (April 1967) (366 pages).

-Fo67b R: E. Forrester, "Post-Irradiation Examination of the NAA-115-2 Irradiation Experiment," NAASR-MEMO-12588, Atomics International Technical Data Record (November 1967) (136 pages)

Fo68 R. E.-Forrester and W. J. Roberts, "In-Pile Behavior of SNAP 8 Experimental Reactor Type. Sublength Fuel Elements (NAA-115-2 Experiment)," Atomics International Report NAA-SR12625 (June 1968) (190/pages) 


\section{NAA-117-1 IN-PILE FUEL EXPERIMENT}

Irradiation start date:

Irradiation end date:

Thermal power:

Irradiation location:

\author{
Not available \\ Not available \\ Not available \\ Hanford K-West Reactor
}

\subsection{NAA-117 GENERAL DESCRIPTION}

NAA-117-1 was one of three similar irradiation experiments (NAA-115-1, NAA-115-2, and NAA-1.17-1). that were statistically designed to test and evaluate SNAP 8 fuel elements. NAA-117-1 differed from the NAA-115 experiments in that it contained 16 sub-length fuel elements with target bumups ranging from 0.3 to 0.8 metal-atom \% (Fo67). The measured burnup ( 0.37 to 0.77 metal-atom \%) is the highest of any of the SNAP fuels. The NAA-117 fuel element pieces were shorter rods taken from the S8ER production inventory and irradiated at the Hanford $\mathrm{K}$-West reactor. Fabrication data, compositions, etc. would thus be as described for the S8ER fuel rods. The fuel elements were formed into 6 separate experimental capsules which were connected in series to form a 15 -foot-long test assembly.

A good general description of the experiment, its objectives, and the results is given in Co67, and a summary of several in-pile experiments, is provided in Bi67.

\subsection{NAA-117 FUEL IDENTIFICATION}

Reactor type: S8ER

Fuel identification: NAA-117

Fuel Specimen Identification: M-1 through M-18 (C067)

Experiment designer, builder: Atomics International

Reactor owner: Atomic Energy Commission (now DOE)

Fuel designer, builder: Atomics Intemational

Fuel owner: Atomic Energy Commission (now DOE)

\subsection{NAA-117 REACTOR EXPERIMENT DESCRIPTION}

Experiment design parameters:

Co67 List of parameters (Table 8) and experiment description; specimens enclosed in six capsules, arranged in series.

Fo67 16 fuel specimens in 6 capsules, schematic layout in Fig. 1

Design neutron flux:

Design neutron energy:

Core element locator: 


\subsection{NAA-117 FUEL FABRICATION INFORMATION}

Fuel specifications and drawings:

C067 Design of fuel element specimens (Fig. 2B, 3)

Fo67 Design of fuel element specimens (Fig. 2)

Co67 Dimensional and compositional data (Table 1), compared with S8ER fuel elements

Fo67 Fuel composition (Table 1)

Fuel fabrication and quality control:

Co67 Fabrication description in Section II

C067. Listing of fuel element specimen numbers (Table 5), along with chem analyses for C,U,H

Co67 Dimensional data and hydrogen leak rates (Tables 6,.7)

Fuel cladding, inner coatings, and other non-fuel materials:

Co67 Fabrication description of cladding, end caps, and plugs in Section II: Hastelloy N;

- chemical analyses and mechanical properties in Table 2

Co67 Cladding inner surface chromized and oxidized for adherence of inner coating to the cladding

Co67 Coating $=$ AI-8763D, composition given (Table 3); Coating thicknesses in Table 4

Potential fuel chemical reactions:

Co67 NaK in contact with cladding outside surface

Potential RCRA-regulated materials:

Quantities of materials:

See shipping spreadsheets (fuel rods, $U,{ }^{235} \mathrm{U}$ )

Fuel assembly identification methods:

\subsection{NAA-117 IRRADIATION HISTORY}

Experiment Operating History:

Fo67 Total irradiation time about 10,000 hours. Centerline temperatures varied from $1300^{\circ} \mathrm{F}$ to $1500^{\circ} \mathrm{F}$. Cladding temperatures varied from 895 to $1315^{\circ} \mathrm{F}$.

Co67 Vague irradiation data (originally classified); thermal data in Fig. 50 - 65

Neutron flux profile:

Operation abnormalities:

\subsection{NAA-117 POST-IRRADIATION PROPERTIES AND EXAMINATION}

Fo67 A detailed description of the post-irradiation examination results

Fo66 A two-volume collection of the photographs from the post-irradiation examination

AI66 8 laboratory notebooks covering the post-irradiation hot-cell examination; Book 6 includes color photomicrographs

Co67 Post-irradiation examination analysis, with results excerpted from Fo67. Includes summary figures of post-irradiation data and photographs of each specimen (Fig. 50 - Fig. 65), except for specimens $M-4, M-8$ 


\section{Visual observations:}

Co67 Visual notations; photographs of heavy spall

Fo66 Books of post-irradiation examination photographs (2 volumes, 774 pages) .

F067 Visual and photographic results, from all states of disassembly; a "frosty" surface was observed on the outside of the as-received fuel elements, thought to be due to water residue on the hot surface of the experiments after they were moved (at Hanford) from the reactor core to the water pit

\section{Dimensions:}

Co67 Comparison pre- and post-irradiation lengths, diameters; pre- and post-irradiation density measurements

Fo67 Dimensional measurements

Metallurgical states of materials:

C067 Discussion of fuel material after irradiation, showing spalling of some specimens; extensive fuel metallography (including photomicrographs)

F067. Metallographic analysis, including numerous photographs; hardness measurements

\section{Cladding defects:}

C067 Cladding photomicrographs showing cladding failures and poor adherence of hydrogen barrier coating in some instances. Cladding metallography, hardness testing, and grain size.

\section{Corrosion or chemical contamination:}

Co67 Photographs of contamination of fuel material by cladding; plus visual descriptions of contamination from $\mathrm{NaK}$ and cladding by specimen number (M-1 through $\mathrm{M}-18$ ).

\section{Hydrogen effects:}

Co67 Pre- and post-irradiation hydrogen analysis; tabulation of $\mathrm{H} / \mathrm{Zr}$ effective.

Fo67 Hydrogen analysis

\section{Burnup:}

Fo67 Bumup analysis; calculated bumups were 0.37 to 0.77 metal-atom \%

C067 Burnup analysis from dosimetry and mass spectrometry; ${ }^{95} \mathrm{Zr}$ gamma activity .

Fission products:

Fo67 . Fission gas analysis; autoradiographs; gamma scan profiles

Co67 Fission gas analysis $\left({ }^{85} \mathrm{Kr}\right)$

Transuranics:

Activation products:

Decay heat generation:

Radiation level decay curves:

Alpha contamination:

(not relevant for the declad fuels) 


\subsection{NAA-117 ON-SITE STORAGE HISTORY}

The NAA 117-1 test assembly was sectioned at Hanford between each of the six capsules and shipped to the Atomics International Hot Laboratory (AIHL) for destructive post-irradiation analysis. They were received at the AIHL in two different cask shipments in the early part of July 1966 (Fo67). The fuel materials were stored at the AIHL while post-irradiation examinations were proceeding, and then shipped to AI's Radioactive Materials Disposal Facility (RMDF) for temporary storage before shipment to INEL. They were always stored in air at both the RMDF and the AIHL. Reference Fo67 indicates some underwater storage of the irradiated test assembly at Hanford on removal from the core and prior to shipment to AI.

\subsection{NAA-117 SHIPPING RECORDS}

The NAA-117-1 fuel rod material from two irradiation capsules, shipped to INEL with the S8ER fuel elements under. shipment LAE-JWA-26, is listed in the S8ER. Shipping Record Summary. Five pieces were shipped to INEL with the S8DR fuel elements in AI Can No. 10, shipment LAE-JSB-02, and are included in the S8DR Shipping Record Summary.

\subsection{REFERENCES}

AI66 Atomics International Laboratory Notebooks "M NAA 117-1," covering NAA-117-1 hot cell examinations: Book 1 (B 326601, July 1966), Book 2 ( B 335101, August 1966), Book 3 (B335051, September 1966), Book 4 (B 326801, September 1966), Book 5 (B 335251, October 1966), Book 6 (B 345401, December 1966), Book 7 (B 345601, January 1967, and Book 8 (B345551, January 1967)

Bi67* K. R. Birney, "An Empirical Study of SNAP Reactor Fuel Irradiation Behavior," Atomics International Report NAA-SR-12284 (August 1967) (51 pages)

Co67. R. C. Courtright and R. E. Forrester, "In-Pile Behavior of SNAP 8 Experimental Reactor Type Sublength Fuel Elements (NAA 117 Experiment)," Atomics Intemational Report NAA-SR-12032 (November 1967) (140 pages)

Fo66 R. E. Forrester, "Postirradiation Photographs for the NAA 117-1 - Experiment," Atomics : Intemational Technical Data Record NAA-SR-MEMO-12212, Volumes 1 and 2 (November 1966) (674 pages)

Fo67 R. E. Forrester, "Post Irradiation Examination of the NAA-117-1 Experiment," Atomics International Technical Data Record NAA-SR-MEMO-12365 (March 1967) (144 pages) 


\section{NAA-121 IN-PILE FUEL EXPERIMENT}

Irradiation start date:

- Discharged:

Thermal power.

Irradiation location:
October 15, 1967 (Le70)

July 4, 1969 (Le70)

Not available

Hanford K-East Reactor

\section{1 · NAA-121 GENERAL DESCRIPTION}

The NAA-121 experiment was a reactor fuel element performance test of eight uranium zirconium hydride fuel rods clad with Hastelloy $N$ and coated with an SCB-1 glass hydrogen barrier. Four of the elements . were irradiated in the Hanford K-East reactor (Le71). The primary objective of the in-pile experiment was to evaluate the performance of three full-length S8DR-type fuel elements under approximated S8DR reactor operating conditions. A fourth test element was included in the irradiation for in-pile phase transformation studies (Fo70). . The uranium concentration in the irradiated fuel rods ranged from 10.32 to $10.58 \mathrm{wt} \%$ (Le71). The four out-of-pile fuel elements were the same as the in-pile elements except . that they contained natural uranium.

The NAA-121 in-pile experimental assembly included four individual experiments, denoted $-1,-2,-3$, and -4 , designed to operate at three different power levels. In some reports these experiments are identified

separately, such as NAA-121-1, and were called capsules (instead of experiments) during post-irradiation

- examination. Report Le71 identifies the overall experiment as NAA-121-1, but covers all.four irradiated capsules.

\subsection{NAA-121 FUEL IDENTIFICATION}

Reactor type: S8DR

Fuel identification: S8DR-type, four full-length elements (Le71)

Fuel Specimen Identification: NAA-121-1, $-2,-3,-4$

Experiment designer, builder: Atomics Intemational

Reactor owner: Atomic Energy Commission (now DOE)

Fuel designer, builder: Atomics International

Fuel owner: Atomic Energy Commission (now DOE)

\subsection{NAA-121 REACTOR EXPERIMENT DESCRIPTION}

Experiment design parameters:

Le70 As-built fuel element data and reference heat generation rates

Le71 In-pile neutron irradiation experiment

Design neutron flux:

Design neutron energy:

Core element locator: 


\subsection{NAA-121 FUEL FABRICATION.INFORMATION}

Fuel specifications and drawings:

Le70 Sketches of fuel element (Fig. 1) and capsule (Fig. 2) design

Le71 Schematic drawing of the fuel element (Fig. 1a)

Drawings available from loose files

Fuel fabrication and quality control:

Le71 Fuel element as-built dimensions and uranium content (Table 1); fuel alloy chemical. composition, including $U$ range of 10.32 to $10.58 \cdot w t \%$ (Table 2)

Fuel cladding, inner coatings, and other non-fuel materials:

Le71 Hastelloy-N cladding, SCB-1 coating; see S8DR

Potential fuel chemical reactions:

Potential RCRA-regulated materials:

Quantities of materials:

See shipping spreadsheets (fuel rods, $U,{ }^{235} \mathrm{U}$ )

Fuel assembly identification methods:

\subsection{NAA-121 IRRADIATION.HISTORY}

Experiment Operating History:

Fo70 - Detailed information on the operational history not reported because of its security classification (see Le70)

Le70 Operations summary (Table 2), including 15,000 hours in-pile time and 11,457 hours time at power, charts of time-temperature history for each thermocouple (Appendix 1); power graphs showing complete time power history of the experiment (Appendix 4)

Le71 Experiment ran for 12,000 hours at cladding temperatures up to $1300^{\circ} \mathrm{F}$ and fuel temperatures up to $1450^{\circ} \mathrm{F}$ at the Hanford K-East reactor. In-pile operations summary (Table 4).

Neutron flux profile:

Operation abnormalities:

\subsection{NAA-121 POST-IRRADIATION PROPERTIES AND EXAMINATION}

Le71 Schematic (Fig. 16) of the sectioning of the fuel rods for post-irradiation examination (hydrogen, metallurgical, and burnup), plus the identification system

Visual observations:

Fo70 Post-irradiation photograph of Elements 1-4 (Fig. 5 - 8)

Le71 Fuel element and fuel material sample photographs 


\section{Dimensions:}

Fo70 Fuel element dimensional profile scans (Fig. 11); density measurements of sections from the four fuel rods (Table VI)

Le71 Density summary (Table 6)

\section{Metallurgical states of materials:}

Le69 Discussion of possible fuel phase changes in Element 4 based on early temperature profile information

Fo70 Neutron radiographs showing fuel-rod cracks and distortions within the cladding (Fig. 10); photographs of fuel rods from Elements 1,2,3 after cladding removal (Fig. 12-14); Element 4 cross section photographs (Fig. 15, approx. 19.pieces); photomicrographs of fuel rods $1,2,3,4$ (Fig. 22 - 25)

\section{Cladding defects:}

Fo70 Element 4 cracked and shows evidence of NaK contamination (Fig. 8)

\section{Corrosion or chemical contamination:}

. Fo70 Element 4 cracked and shows evidence of NaK contamination (Fig. 8)

Hydrogen effects:

Le70 Pre- and post-irradiation fuel rod hydrogen content

Fo70 Hydrogen analysis from Elements 1,2,3 (Table VIII)

Mi71 Hydrogen analysis (Table I)

Le71 Hydrogen retention summary (Table 6); barrier performance (hydrogen loss; Table 7) . .

\section{Burnup:}

Fo70 Calculated bumups based on temperature history (Table II)

Mi71 Fuel burnup anälysis (Table II); source analytical chemistry data sheets by mass spectrometry are available

Le71 Peak burnup of 0.32 metal-atom \%; bumup summary (Table 6)

Fission products:

.Sw69a Preliminary fission gas release computation for Elements 1,2,3

Le71 Fission gas release summary (Table 8)

Fo70 Gamma scan profiles of the 4 elements (Fig. 9)

Transuranics:

Activation products:

Decay heat generation:

Radiation level decay curves:

Alpha contamination:

(not relevant for the declad fuels)

\subsection{NAA-121 ON-SITE STORAGE HISTORY}

The NAA-121 test assembly was sectioned at Hanford between each of the four experiments and the shroud tubes were removed. The experiments (capsules) were then shipped to the Atomics International Hot Laboratory (AIHL) for destructive post-irradiation analysis (Fo70). This analysis began in August 1969. The fuel materials were stored at the AIHL while post-irradiation examinations were proceeding, 
and then shipped to AI's Radioactive Materials Disposal Facility (RMDF) for temporary storage before shipment to INEL. They were always stored in air at both the RMDF and the AIHL.

\subsection{NAA-121 SHIPPING RECORDS}

The NAA-121 fuel rod material (from Experiments 1,2,3, and 4) shipped to INEL is listed in the S8DR Shipping Record Summary, where it is included under shipment LAE-JSB-02.

\subsection{REFERENCES .}

Fo70 R. E. Forrester, "Post-Irradiation Examination of the NAA-121 Irradiation Experiment," Atomics International Technical Data Record AI-AEC-MEMO-12940 (March 1970). (53 pages)

Le69 J. G. LeBlanc and J. R. Miller, "NAA 121-1-4 Cladding Temperature Profiles,". Atomics Intemational Technical Information Document TI-696-24-048 (December 1969). (7 pages)

Le70 J. G. LeBlanc and H. J. Tribfelner, "NAA 121-1 Irradiation Experiment Operations Report," Atomics International Technical Data Record AI-AEC-MEMO-12930 (February 1970) (218 pages)

Le71 J. G. LeBlanc, "Prototype S8DR Fuel Element Performance Test (NAA 121-1 Experiment)," . Atomics Intemational Report AI-AEC-13002 (July 1971) (61 pages)

Mi71 K. J. Miller, "NAA-121 Fuel Bumup and Hydrogen Analysis," Atomics Interriational Technical . Information Document TI-696-240-083 (March 1971) (7 pages)

Sw69a L. .D. Swensen, "Preliminary Computed Fission Gas Release Fraction from NAA-121-1 Fuel Elements," Atomics International Technical Information Document TI-568-24-032 (November 1969) (4 pages) 


\section{NAA-67 IN-PILE FUEL EXPERIMENT}

Rebecca Lords of WINCO provided the information during her visit to ETEC on 22-23 September 1994 - that two SNAP NAA-67 fuel pieces were also in storage at INEL. We have not located any documented evidence of this experiment, and have no descriptive information on it at this time. However, based on Ms. Lords' input, we have reviewed our archived shipping records and have identified shipments of NAA67 irradiation capsules both to and from INEL (Phillips Petroleum Company). This indicates that some NAA-67 materials were sent to INEL-for one or more irradiation experiments and subsequently retumed to AI for analysis. These shipments are summarized as follows:

Shipments to INEL:

$\begin{array}{llll}\text { Date } & \text { Sample Identification } & \text { Uranium } & { }^{235} \mathrm{U} \\ & & & \\ 04 / 26 / 62 & \text { NAA-67-1,2 No. 1,2,3,4,7,8,9,10 } & 203 \mathrm{~g} & 190 \mathrm{~g} \\ 05 / 07 / 62 & \text { NAA-67-1,2 } 14 \text { rod pieces } & 457 \mathrm{~g} & 425 \mathrm{~g} \\ \text { Totals: } & 22 \text { samples } & 660 \mathrm{~g} & 615 \mathrm{~g}\end{array}$

Shipments from INEL:

$\begin{array}{llcc}\text { Date } & \text { Sample Identification } & \text { Uranium } & { }^{235} \mathrm{U} \\ 10 / 02 / 62 & \text { NAA-67-1 } & 46.0 \mathrm{~g} & 43.0 \mathrm{~g} \\ 11 / 19 / 62 & \text { NAA-67-3 } & 46.0 \mathrm{~g} & 43.0 \mathrm{~g} \\ 09 / 17 / 62 & \text { NAA-67-4 } & 42.0 \mathrm{~g} & 39.0 \mathrm{~g} \\ 11 / 23 / 62 & \text { NAA-67-5 } & 46.3 \mathrm{~g} & 43.0 \mathrm{~g} \\ 08 / 10 / 62 & \text { NAA-67-6 } & 46.3 \mathrm{~g} & 43.0 \mathrm{~g} \\ 03 / 15 / 63 & \text { NAA-67-7 } & 5.8 \mathrm{~g} & 5.5 \mathrm{~g} \\ 03 / 15 / 63 & \text { NAA-67-8 } & 5.8 \mathrm{~g} & 5.5 \mathrm{~g} \\ 03 / 15 / 63 & \text { NAA-67-9. } & 5.7 \mathrm{~g} & 5.5 \mathrm{~g} \\ 03 / 15 / 63 & \text { NAA-67-10 } & 5.7 \mathrm{~g} & 5.5 \mathrm{~g} \\ 08 / 10 / 62 & \text { NAA-67-11 } & 46.2 \mathrm{~g} & 43.0 \mathrm{~g} \\ 11 / 23 / 62 & \text { NAA-67-12 } & 46.2 \mathrm{~g} & 43.0 \mathrm{~g} \\ 10 / 26 / 62 & \text { NAA-67-13 } & 41.5 \mathrm{~g} & 38.7 \mathrm{~g} \\ 11 / 27 / 62 & \text { NAA-67-14 } & 41.5 \mathrm{~g} & 38.7 \mathrm{~g} \\ 03 / 15 / 63 & \text { NAA-67-15 } & 41.5 \mathrm{~g} & 38.7 \mathrm{~g} \\ 03 / 15 / 63 & \text { NAA-67-16 } & 41.5 \mathrm{~g} & 38.7 \mathrm{~g} \\ 03 / 15 / 63 & \text { NAA-67-17 } & 41.5 \mathrm{~g} & 38.6 \mathrm{~g} \\ 03 / 15 / 63 & \text { NAA-67-18 } & 41.5 \mathrm{~g} & 38.6 \mathrm{~g} \\ 11 / 19 / 62 & \text { NAA-67-19 } & 5.8 \mathrm{~g} & 5.3 \mathrm{~g} \\ 11 / 08 / 62 & \text { NAA-67-21 } & 5.7 \mathrm{~g} & 5.2 \mathrm{~g} \\ 09 / 17 / 62 & \text { NAA-67-22 } & 5.7 \mathrm{~g} & 5.2 \mathrm{~g} \\ \text { Totals: } & \text { 20 samples } & & \\ & & 608.2 \mathrm{~g} & 566.7 \mathrm{~g}\end{array}$

The return shipping documents account for 20 of the 22 samples shipped to INEL. The two samples that were apparently not retumed to AI, based on the numbering sequence of the samples that were returned, 
were samples NAA-67-2 and NAA-67-20. The material mass not returned, based on the differences between the two sets of totals, was $51.8 \mathrm{~g}$ of uranium, of which $48.3 \mathrm{~g}$ was ${ }^{235} \mathrm{U}$ (neglecting differences . in round-off conventions). Based on the masses of samples with neighboring identification numbers, one . would guess that NAA-67-2 weighed $46 \mathrm{~g}\left(43 \mathrm{~g}\right.$ of $\left.{ }^{235} \mathrm{U}\right)$ and NAA-67-20 weighed $5.7 \mathrm{~g}\left(5.2 \mathrm{~g}\right.$ of $\left.{ }^{235} \mathrm{U}\right)$. Their sum accounts for the difference between the AI-shipped and AI-received total NAA-67 uranium . masses, within round-off differences. 


\section{APPENDICES}




\section{APPENDIX 1 COMBINED LISTING OF REFERENCE DOCUMENTS}

- Ad74 T. Adamson (Aerojet Nuclear), in Atomics International Telephone Conversation Record to V.J. Schaubert (AI) dated 28 January 1974

AI65 Atomics International, "S8ER. Screening Examination Dry Weight Data Sheets in Sequence from Ring I to Ring IX," Atomics International binder of source data sheets

AI66 Atomics International Laboratory Notebooks "M NAA 117-1," covering NAA-117-1 hot cell examinations: Book 1 (B 326601, July 1966), Book 2 ( B 335101, August 1966), Book 3 (B335051, September 1966), Book 4 (B 326801, September 1966), Book 5 (B 335251, October . 1966), Book 6 (B 345401, December 1966), Book 7 (B 345601, January 1967, and Book 8 (B345551, January 1967)

AI66a Atomics Intemational Hot Laboratory Staff, "[S8ER] Post Irradiation Screening Examination' Photographs," Atomics International Technical Data Records NAA-SR-MEMO-12011, Volumes I to XIV (1966) (volumes not labeled with NAA number)

AI66b Atomics International Hot Laboratory Staff, "Ș8ER Screening Examination Stereo Data Sheets in Sequence from Ring I to Ring IX," Atomics International source data book (1966)

AI66c Atomics Intemational Hot Laboratory Staff, "S8ER Screening Examination Length Measurement Data Sheet in Sequence from Ring I to Ring IX," Atomics International source data book (1966)

AI66d Atomics Intemational Hot Laboratory Staff, "S8ER Screening Examination Gamma Scanning Data Sheets in Sequence from Ring I to Ring IV, from Ring .V to Ring VII, and from Ring VIII to Ring IX," Atomics International source data books, 3 volumes (1966)

AI66e Atomics International Hot Laboratory Staff, "S8ER Screening Examination Diameter Measurements Data Sheets in Sequence from Ring I to Ring V, and from Ring VI to Ring IX," Atomics International source data books, 2 volumes (1966)

AI66f Atomics Intemational Hot Laboratory Staff, "S8ER Screening Examination Hydrogen Analysis Data Sheets in Sequence from Ring I to Ring IX," Atomics Intemational source data book (1966)

Am68 C. B. Amberson (Idaho Nuclear Corporation), "SNAP Fuels from A.I. in 1967-1968 Fai-9-68," Interoffice Correspondence

AN76 Anonymous, "Zirconium Hydride (SNAP) Reactor Space Power Programs. Summary of Major Activities and Accomplishments," Rockwell International Energy Systems Group (June 1976)

An83 R. V. Anderson, et al., "Space Reactor Electric Systems. Subsystem Technology Assessment," Rockwell International Energy Systems Group Report ESG-DOE-13398 (March 1983)

Ar63 J. R. Armstrong, et al,, "SNAP 10 A FS-3, -4, and -5 Fabrication Process Sheets and Auxiliary Forms," Atomics Intemational Technical Data Record NAA-SR-MEMO-8809 (July 1963) (41 pages) 
Ar74 J. R: Armstrong, "Uranium-Zirconium Fuel Alloy, Hydriding of," Atomics International Specification NA0611-001 (January 1974) (11 pages)

Ar77 D. V. Amold, C. C. Woolsey, and W. H. Friske, "Specification for Marking," Atomics Intemational Specification N001A0104001 (June 1977) (7 pages)

Be62 J. P. Beall and M. W. Hulin, "SNAP-2 Experimental Reactor Operation and Test Program," Atomics International Report NAA-SR-7088 (April 1962) (76 pages)

Be94 C. L. Bendixsen, in Proc. 1994 International High Level Radioactive Waste Management Conference, American Nuclear Society, 22-26 May 1994

Bi67* K. R. Bimey, "An Empirical Study of SNAP Reactor Fuel Irradiation Behavior," Atomics International Report NAA-SR-12284 (August 1967) (51 pages)

B159 M. Bloomfield, "Tentative SER Fuel Element Inspection Specification," Atomics International Memorandum NAA-SR-MEMO-4063 (June 1959) (8 pages)

Bu64 G. F. Burdi, Ed., "SNAP Technology Handbook. Volume II. Hybrid Fuels and Claddings," Atomics International Report NAA-SR-8617, Volume II (November 1964) (129 pages)

Bu67* J. S. Buck, W. E. Krupp, and.T. A. Park, "Irradiation Performance of a Full-Scale Prototype SNAP 2 Reactor Fuel Element," Atomics International Report NAA-SR-12030 (August 1967) (82 pages)

Bu70 D. S. Burgess, "Statistical Evaluation of the Fuel-Clad Gap and Crack Length from S8DR Fuel Elements," Atomics Intemational Technical Information Document TI-568-24-05़8 (June 1970) (14 pages)

Ca63 D. C: Campbell, et al., "SNAP 8ER Fabrication Process Sheets and Auxiliary Forms," 'Atomics Intemational Technical Data Record NAA-SR-MEMO-8273 (February 1963) (41 pages)

Ca63a D. C. Campbell, et al., "SNAP 10A FS-1 Fabrication Process Sheets and Auxiliary Forms," Atomics International Technical Data Record NAA-SR-MEMO-8272 (February 1963) (37 pages)

Ca64 D. C. Campbell, et al., "SNAP 8 Experimental Reactor Fabrication and Engineering," Atomics International Report NAA-SR-8430 (March 1964) (55 pages)

Ce64 W. M. Cegelski, "Fission Product Release from Irradiated Uranium-Zirconium Hydride SNAP Fuel;" Atomics Intemational Report NAA-SR-9673 (July 1964) (37 Dages)

Co67 R. C. Courtright and R. E. Forrester, "In-Pile Behavior of SNAP 8 Experimental Reactor Type Sublength Fuel Elements (NAA 117 Experiment)," Atomics International Report NAA-SR-12032 (November 1967) (140 pages)

Co71 L. Cooper, "Results from Abbreviated EMP Examination of Three S8DR Imadiated Fuel Specimens," Atomics International Technical Information Document TI-653-240-003 (July 1971) (7 pages) 
Cu65 - G. E. Culley, "Analysis of SNAPTRAN-3 Destructive Experiment Debris," Atomics Intemational Report NAA-SR-11584 (December 1965) (37 pages)

Da70 N. F. Davies, "S8DR Examination," Atomics International Technical Information Document TI568-24-049 (April 1970) (3 pages)

Da70a W. H. Dauterman, "Bowing of S8DR Fuel," Atomics International Technical Information Document TI-568-24-042 (March 1970) (20 pages)

De62*.W. F. Dennison and T. S. Jakobowski, "Assembly of S-2 DR Fuel Elements," Atomics Intemational Report NAA-SR-7048 (December 1962) (26 pages)

De65 R. L. Detterman, "Progress Report: SNAP Aerospace Safety Program April-June 1965," -Atomics Intemational Report NAA-SR-11497 (August 1965) (one of a series, 39 pages)

De67 W. F. Dennison and P. J. Fessia, "Fuel Element Assembly, S8DR," Atomics International Specification ST0622NA0041 (May 1967) (14 pages)

Di67 H. M. Dieckamp, "Nuclear Space Power Systems," Atomics Intemational (September 1967) . (unpublished book, 388 pages)

Do67 J. P. Dooley and J. P. Beall, "The Disassembly and Postoperation Component Examination of the SNAP 10A FS-3," Atomics Intemational Report NAA-SR-12504 (September 1967) · (70 pages)

Do68* C. Donnelly and W: Nagel, "S8DR Fuel Element Quality Assurance Record," Atomics Intemational Technical Data Record AI-AEC-TDR-12702 (March 1968) (137 pages)

Dr60 P. S. Drennan, "Melting and Forming of SER Fuel Rods," Atomics International Report NAA-SR4762 (October 1960) (30 pages)

Dr61 P. S. Drennan and W. Sawicky, "Summary of Test Data for S-2-DR Fuel Elements," Atomics International Tèchnical Data Record NAA-SR-MEMO-6745 (September 1961) '(32 pages)

Eg59 R. R. Eggleston and G. L. Schmidt, Ed., "SNAP II Experimental Reactor Hazards Report," Atomics Intemational Report NAA-SR-3465 (April 1959) (156 pages)

Ei70 R. L. Eichelberger, "Coating on S8DR Fuel Cladding," North American Rockwell Corporation Aerospace and Systems Group Intemal Letter dated 3 August 1970 (6 pages)

Fe59 L. D. Felten, "Axial Temperature Distribution of S.E.R. Central Fuel Element," Atomics International Technical Data Record NAA-SR-MEMO-5121 (October 1959) (8 pages)

Fe64 L. D. Felten, et al., "Final Report on the SNAP 2 Development Reactor (S2DR) Test Program," Atomics International Report NAA-SR-8295 (April 1964) (156 pages)

Fi94 D. L. Fillmore, "Categorization of Department of Energy Spent Nuclear Fuel," in Proc. 1994 International High Level Radioactive Waste Management Conference, American Nuclear Society, 22-26 May 1994 
Fo66 R. E. Forrester, "Postirradiation Photographs for the NAA 117-1 Experiment," Atomics International Technical Data Record NAA-SR-MEMO-12212, Volumes 1 and 2 (November 19 66) (674 pages)

F067 R. E. Forrester, "Post Irradiation Examination of the NAA-117-1 Experiment," Atomics International Technical Data Record NAA-SR-MEMO-12365 (March 1967) (144 pages)

F067a R. E. Forrester, "Post-Irradiation Photographs for the NAA 115-2 Experiment," Atomics International Technical Data Record NAA-SR-MEMO-12430 (April 1967) (366 pages)

F067b R. E. Forrester, "Post-Irradiation Examination of the NAA-115-2 Irradiation Experiment," NAASR-MEMO-12588, Atomics International Technical Data Record (November 1967) (136 pages)

Fo68 R. E. Forrester and W. J. Roberts, "In-Pile Behavior of SNAP 8 Experimental Reactor Type Sublength Fuel Elements (NAA-115-2 Experiment)," Atomics Intemational Report NAA-SR12625 (June 1968) (190 pages)

Fo70 R.E. Forrester, "Post-Irradiation Examination of the NAA-121 Imadiation Experiment," Atomics International Technical Data Record AI-AEC-MEMO-12940 (March 1970) (53 pages)

Gi56 P. T. Gilbert, Jr., "Zirconium Hydride: A Compendium on the Systems Zirconium-Hydrogen and Hafnium-Hydrogen and Related Topics,". Atomics Intemational Report NAA-SR-1508 (October 1956) (834 pages)

Go67* T: A. Golding, "Post-Operation Evaluation of Fuel Elements from the SNAP 10 Flight System 3 Reactor," Atomics International Report NAA-SR-12031 (September 1967) (41 pages)

Go67a T. A. Golding, "Post-Irradiation Screening Examination of the S10FS-3 Fuel Elements," Atomics International Technical- Data Record NAA-SR-MEMO-12338 (February 1967) (29 pages)

Go67b T. A. Golding, "Post-Irradiation Examination of Selected S10FS-3 Fuel Elements," Atomics

. Intemational Technical Data Record NAA-SR-MEMO-12341 (June 1967) (28 pages)

Go67c K. G. Golliher, et al., "SNAP Engineering Test Facility Safety Analysis Report: Addendum for Intrinsic Supercriticality Experiments," Atomics International Technical Data Record NAA-SRMEMO-12614 (November_1967) (80 pages)

Gr83 L. F. Grantham, et al., "Process Description and Plant Design for Preparing Ceramic High Level Waste Forms," Rockwell International Energy Systems Group Report ESG-DOE-13397 (February 1983) (71 pages)

Ha65 S. D. Harkness, "The Oxidation Kinetics of SNAP Fuel Alloy: Modified 90-10 ZirconiumUranium," Atomics International Technical Data Record NAA-SR-MEMO-10914 (January 1965) (33 pages)

Ha69 F. J. Halfen, "Summary of Selected S8DR Operating Data from 1-19-69 to 4-28-69," Atomics International Technical Information Document TI-696-13-033 (May 1969) (19 pages)

Hu61 M. W. Hulin and J. Beall, Ed., "Preliminary Results of the SNAP 2 Experimental Reactor," Atomics Intemational Report NAA-SR-5991 (April 1961) (60 pages) 
Hu64 H. J. Hubbell and W. E. Nagel, "SNAP 8 Experimental Reactor Fuel Element Acceptance . Testing," Atomics International Report NAA-SR-8589 (March 1964) (63 pages)

Ja73 A. A. Jarrett, "SNAP 2 Summary Report," Rockwell International, Atomics Intemational Division Report AI-AEC-13068 (July 1973) (190 pages)

Jo61* R. P. Johnson, "SNAP Shield Test Experiment Operations Manual," Atomics Intemational Report NAA-SR-5897 (June 1961) (196 pages)

Jo64 H. E. Johnson, "Hydrogen Dissociation Pressures of Modified SNAP Fuels," Atomics International Report NAA-SR-9295 (March 1964) (47 pages)

Ka59 N. H. Katz, "SER Data Report," Atomics International Memo NAA-SR-MEMO-4722 (December 1959) (25 pages)

Ke70 N. Ketzlach, "Criticality Study - S8DR Core Disassembly," Atomics International Technical Information Document TI-568-24-041 (January 1970) (15 pages)

Ke71 N. Ketzlach, "Storage of S8DR Fuel at RMDF," Atomics Intemational Technical Information Document TI-568-240-083 (May 1971) (4 pages)

Ki63 - T. S. Kirsch, "Specifications for Alloying. and Forming SNAP. 10A and 2 Fuel Materials," Atomics Intemational Technical Data Record NAA-SR-MEMO-6645, Revised (August 1963) (15 pages)

Kr66 W. E. Krupp, "Post-Irradiation Examination of the NAA 82-1 Experiment," Atomics International - Technical Data Record NAA-SR-MEMO-11891 (March 1966) (51 pages)

Kr67 W. E. Krupp, "Post-Irradiation Metallographic Examination. of Selected S10FS-3 Reactor Components," Atomics International Technical Data Record NAA-SR-TDR-12390 (March 1967) (10 pages)

La51 R. A. Laubenstein, "Preliminary Considerations on the Feasibility of an Auxiliary Power Plant to be Operated from Radioactive Fission Products," Atomics Intemational Report NAA-SR-152 (October 1951) (22 pages)

La67 K. Langrod, "Process Flow Sheets - S8DR Hydrogen Barrier Material Fabrication," Atomics International Technical Data Record NAA-SR-MEMO-12469 (May 1967) (27 pages)

La68 E. M. Larson, "Radiological Safety and Hazardous Materials Handbook for Building 059," Atomics International Technical Data Record AI-AEC-12682 (April 1968) (part of S8DR Operations Manual)

La68a E. M. Larson, "S8DR Operations Manual," Atomics Intemational Technical Data Record AI-AEC12683 (May 1968) (part of S8DR Operations Manual)

La68b E. M. Larson, "SNAP Ground Prototype Test Facility (Building 059)," Atomics International Technical Data Record AI-AEC-12684 (April 1968) (part of S8DR Operations Manual)

Le66 S. $\dot{K}$. Lee, "A Study of Dehydriding of S8ER Fuel," Atomics Intemational Technical Data Record NAA-SR-MEMO-12197 (October 1966) (20 pages) 
Le69 J. G. LeBlanc and J. R. Miller, "NAA 121-1-4 Cladding Temperature Profiles," Atomics Intemational Technical Information Document TI-696-24-048 (December 1969) (7 pages)

Le70 J. G. LeBlanc and H. J. Tribfelner, "NAA 121-1 Irradiation Experiment Operations Report," Atomics Intemational Technical Data Record AI-AEC-MEMO-12930 (February 1970) (218 pages)

Le71 J. G. LeBlanc, "Prototype S8DR Fuel Element Performance Test (NAA 121-1 Experiment)," Atomics Intemational Report AI-AEC-13002 (July 1971) (61 pages)

Li70 A. F. Lillie, "The S8DR Screening Examination," Atomics International Technical Information Document TI-568-240-068 (October 1970) (112 pages)

Li70a A. F. Lillie and K. J. Miller, "S8DR Screening Examination Weekly Status Reports," Atomics International Technical Information Documents: \#1 (TI-568-24-046, $20^{\circ}$ March 1970, 5 pages), \#2 (TI-568-24-048, 27 March 1970, 8 pages), \#3 (TI-568-24-050, 3 April 1970, 8 pages), \#4 (TI568-24-051, 10 April 1970, 13 pages); \#5 (TI-568-24-052, 17 April 1970, 27 pages), \#6 (TI-56824-053, 24 April 1970, 22 pages), \#7 (PSR-568-24-001, 1 May 1970, 17 pages), \#8 (PSR-568-24002, 8 May 1970, 13 pages), \#9 (PSR-568-24-003, 15 May 1970, 15 pages), \#10 (PSR-568-24004, 22 May 1970, 31 pages), \#11 (PSR-568-24-005, 29 May 1970, 19 pages), \#12 (PSR-568-24006, 5 June 1970, 31 pages), \#13 (PSR-568-24-007, 12 June 1970, 38 pages), \#14 (PSR-568-24008, 19 June 1970, 29 pages), \#15 (P.SR-568-24-009, 26 June 1970, 26 pages), and \#16 (PSR-56824-010, 3 July 1970, 22 pages)

Li71* A. H. Lillie and V.'L. Rooney, Jr., "The SNAP 8 Developmental Reactor (S8DR)' Post-Test Examination," Atomics International Report AI-AEC-13003 (June 1971) (93 pages)

Li73 A. F. Lillie, D. T. McClelland, W. J. Roberts, and J. H. Walter, "Zirconium Hydride Fuel Element Performance Characteristics," Atomics International Report AI-AEC-13084 (June 1973) (75 pages)

Lu64 L. B. Lundberg, "Parametric Studies on the Short-Term Tensile Mechanical Properties of Zr-10U Alloy Hydrides," Atomics Intemational Report NAA-SR-9875 (July 1964) (42 pages)

Ma64 C. A. Martin and W. H. Timmerman, "Process Flow Sheet for SNAP 8DS Melting and Extruding," Atomics International Technical Data Record NAA-SR-MEMO-9630 (March 1964) (17 pages)

Ma67 C. A. Martin, "Process Flow Sheets - S8DR Cup Plugs," Atomics Intemational Technical Data Record NAA-SR-MEMO-12470 (May 1967) (18 pages)

Mc65 D. D. McAfee, "Hot Laboratory Metallography of SNAP 8 Fuel," Atomics International Technical Data Record NAA-SR-MEMO-11217 (March 1965) (12 pages)

Mc67 D. T. McClelland, "Process Flow Sheets - S8DR Fuel Element Fabrication," Atomics Intemational Technical Data Record NAA-SR-MEMO-12473 (May 1967) (19 pages)

Mc67a D. T. McClelland, K. Langrod, and C. A. Martin, "Process Flow Sheets - S8DR Cladding Tube Fabrication," Atomics Intemational Technical Data Record NAA-SR-MEMO-12475 (May 1967) (67 pages) 
Mc69 D. T. McClelland, "S8DR Fuel Rod Fabrication," Atomics International Technical Data Record AI-AEC-TDR-12775 (January. 1969) (43 pages)

Mc69a D. T. McClelland, "SNAP 8 Development Reactor Fuel Element Fabrication," Atomics Intemational Report AI-AEC-12806 (June 1969) (55 pages)

Mc71 W. R. McCumin, "S8DR Fuel Canning and Storage," North American Rockwell Internal Letter dated 22 June 1971 (5 pages)

Mc71a W. R. McCumin, "FINAL S8DR Fuel Canning and Storage," North American Rockwell Internal Letter dated 30 June 1971 (5 pages)

Mc83 R. L. McKisson, et al., "Commercial High Level Waste Management, Options and Economics: A Comparative Analysis of the Ceramic and Glass Waste Forms, " Rockwell International Energy Systems Group Report ESG-DOE-13391 (February 1983) (145 pages)

Mi63* J. R. Miller, "Postirradiation Evaluation of SER Fuel Elements," Atomics Intemational Report NAA-SR-8090 (May 1963) (29 pages)

Mi64 K. J. Miller, "Postirradiation Examination of the SNAP-2 Developmental Reactor Fuel Elements," Atomics Intemational Technical Data Record NAA-SR-MEMO-9753 (April 1964) (74 pages)

Mi65 S. Minor, L. Bixon, and D. Brinkman; "Preliminary Test Results - SNAP 10A FS-3," Atomics International Report NAA-SR-11206 (September 1965) (44 pages)

Mi66 - K. J. Miller, "Post-Irradiation Screening Examination of the S8ER Fuel Elements," Atomics International Technical Data Record NAA-SR-MEMO-11880 (March 1966) (299 pages)

Mi66a K. J. Miller, "Post-Irradiation Detailed Examination of Selected S8ER Fuel Elements," Atomics International Technical Data Record NAA-SR-MEMO-12165 (1966) (complete color copy) (304 pages)

Mi66b K. J. Miller, "S8ER Screening Examination Photograph Books," Atomics Intemational Internal Letter to G. W. Meyers dated 17 June 1966

Mi67 K. J. Miller, "Electron Microscopy Analysis of Irradiated S8ER and NAA 115-1 Fuel," Atomics Intemational Technical Data Record NAA-SR-MEMO-12368 (March 1967) (51 pages)

Mi67a K. J. Miller, "Electron Microscopy Analysis of Irradiated SNAP 8 Fuel," Atomics International Report NAA-SR-12449 (August 1967) (66 pages)

Mi69 K. J. Miller, "S8DR Examination Planning Document for AIHL," Atomics Intemational Test Plan TP-568-24-004 (November 1969) (51 pages)

Mi69a K. J. Miller, "S8DR Examination Planning Document for AIHL," Atomics International Technical Information Document TI-568-24-037 (December 1969) (42 pages)

Mi70 K. J. Miller, "Selection of S8DR Fuel Elements for the Detailed Postirradiation Examination," Atomics International Technical. Information Document TI-568-24-061 (June 1970) (11 pages) 
Mi70a K. J. Miller, et al., "S8DR Detailed Examination Progress Report," Atomics International Program Status Reports: Number 1 (PSR-568-240-011, September 1970, 36 pages), Number 2 (PSR-568240-012, October 1970, 62 pages), Number 3 (PSR-568-240-013, November 1970, 54 pages), Number 4 (PSR-568-240-014, December 1970, 11 pages), Number 5 (PSR-568-240-015, January 1971, 15 pages), Number 6 (PSR-568-240-016, February 1971, 44 pages), Number 7 (PSR-568240-017, March 1971, 26 pages), Number 8 (PSR-568-240-018, May 1971, 23 pages), Number 9 (PSR-653-240-001, July 1971, 92 pages), and Number 10 (PSR-653-240-002, July 1971, 29 pages)

Mi70b K. J. Miller, "S8DR Fuel Accountability Losses at AIHL," North American Rockwell Corporation Aerospace and Systems Group Intemal Letter dated 21 December 1970 (2 pages)

Mi70c M. Mike, "Fuel Rod Dimensional Data/Plots From N-Ray -Results - S8DR Screening Examination," Atomics International Technical Information Document TI-568-24-066 (July 1970) (213 pages)

Mi71 K. J. Miller, "NAA-121 Fuel Burnup and Hydrogen Analysis," Atomics International Technical Information Document TI-696-240-083 (March 1971) (7 pages)

Mo68 L. Morrison and E. L. Babbe, "S8ER Fuel Rod and Fuel Element Pre-Irradiation Measurements," Atomics International Technical Information Document TI-S8DR-28-012 (May 1968) (16 pages)

Mo68a K. E. Moore, W. A. Young, M. M. Nakata, and C. A. Smith, "Phase Relations at High Hydrogen Contents in the SNAP Fuel System," Atomics International Report NAA-SR-12587 (February 1968) (55 pages)

"Mo68b K. E. Moore and M. M. Nakata, "Phase Relationships in the $(\alpha+\delta)$ Region of the Zr-H System," Atomics Intemational Report AI-AEC-12703 (September 1968) (47 pages)

Mo90 W. G. Moffett, Ed., The Handbook of Binary Phase Diagrams, Vol. V.(Genium Publishing Co., Schenectady, NY, 1990 update)

Na62 W. E. Nagel, "S8ER Fuel Element Data Package," Atomics International Technical Data Record NAA-SR-MEMO-7623 (October 1962) (1078 pages)

Na63 W. E. Nagel, "S8ER Fuel Element Quality Control - Upgrading Point Tests and Inspections," Atomics International Technical Data Record NAA-SR-8283 (February 1963) (44 pages)

Na67 M. M. Nakata, C. J. Ambrose, and R. A. Finch, "Thermophysical Properties of SNAP Fuel Materials," Atomics Intemational Report NAA-SR-I1959 (September 1967) (93 pages)

0163 P. S. Olson, "Hot Cell Examination Requirements of S2DR Fuel Elements," Atomics International Technical Data Record NAA-SR-8716 (July 1963) (8 pages)

0165* P. S. Olson, " Evaluation of Fuel Elements from SNAP 2 Developmental Reactor Core," Atomics International Report NAA-SR-9648 (January 1965) (35 pages).

0167* P. S. Olson, K. J. Miller, and E. J. Donovan, "Postoperation Evaluation of Fuel Elements from the SNAP 8 Experimental Reactor," Atomics International Report NAA-SR-12029 (September 1967) (223 pages) 
0191 R. D. Oldenkamp and J. C. Mills, "Nuclear Operations at Rockwell's Santa Susana Field Laboratory - A Factual Perspective," Rockwell .Intemational, Rocketdyne Division Supporting Document N001ER000017 (September 1991) (95 pages)

Pe66 H. Peariman, et al., "SNAP 8 Experimental Reactor Fuel Element Behavior: Atomics International Task Force Review," Atomics International Report NAA-SR-MEMO-12210 (November 1966) (73 pages)

Ra63 J. W. Raymond, "Development of a High Yield $90 \mathrm{Zr}-10 \mathrm{U}$ Alloy Massive Hydride," Atomics International Report NAA-SR-7305 (January 1963) (22 pages)

Ra65 J. W. Raymond, "Phase Relationships and Microstructures in the Zirconium - 10 wt \% Uranium Alloy Hydride System," Atomics Intemational Report NAA-SR-10965 (November 1965) (36 pages)

Ra65a J. W. Raymond and D. T. Shoop, "The Metallography of Zirconium-Base Alloy Hydrides," Atomics Intemational Technical Data Record NAA-SR-TDR-10927 (February 1965) (9 pages)

Re59 E. L. Reed, "SER Fuel Element Specification," Atomics Intemational Intemal Letter dated 11 June 1959 (4 pages)

R061* C. J. Romero and S. Elchyshyn, "Cladding Development for SER Fuel Elements," Atomics Intemational Report NAA-SR-4831 (Febrary 1961) (42 pages)

Ro70 H. Rood, "S8DR Fuel Burnup and Transmutation Data," Atomics International Technical Information Document TI-568-24-063 (July 1970) (5 pages)

Sa63 W. Sawicky, "Fabrication Process Test and Inspection Sheets for SNAP 10A Flight System Cores 3, 4, and 5 Fuel Elements," Atomics International Technical Data Record NAA-SR-MEMO-9367 (November 1963) (46 pages)

Sa64 W. Sawicky, "SNAP 10A FS-1 Core-Fuel Element Data Packages for First Delivery," Atomics International Technical Data Record NAA-SR-MEMO-9855 (April 1964) (414 pages)

-Sa64a W. Sawicky, "SNAP 10A FS-1 Core-Fuel Element Data Packages for Second Delivery," Atomics International Technical Data Record NAA-SR-MEMO-9926 (May 1964) (192 pages)

Sa64b W. Sawicky, "SNAP 10A FS-3 Core-Fuel Element Data Packages," Atomics International Technical Data Record NAA-SR-MEMO-10033 (June 1964) (171 pages)

Sa64c W. Sawicky, "SNAP 10A FS-4 Core-Fuel Element Data Packages," Atomics International Technical Data Record NAA-SR-MEMO-10208 (July 1964) (171 pages)

Sa64d W. Sawicky, "Addendum to SNAP 10A FS-1, FS-3, and FS-4 Fuel Data Packages for FS-3, FS-4, and FS-5 Systems," Atomics Intemational Technical Data Record NAA-SR-MEMO-10815 (December 1964) (84 pages)

Sa66 W. B. Sayer and R. S. Hart, "The Predicted Fission Product Decay of Snapshot-1," Atomics Intemational Report NAA-SR-11642 (January 1966) (20 pages) 
Sc65 A. R. Schmitt, "Post-Irradiation Examination of NAA-82-1," Atomics International Internal Letter dated 27 October 1965 (4 pages)

Sc70 F. G. Schmidt, "S8DR Fuel Element Sample Numbering System," North American Rockwell Corporation Aerospace and Systems Group Internal Letter dated 13 July 1970 (2 pages).

Sc71 F. G. Schmidt, "S8DR Fuel Cutting Losses Assigned to Scrap at AIHL," North American Rockwell Corporation Aerospace and Systems Group Internal Letter dated 1 July 1971 (1 page)

Sc73 F. G. Schmidt, "Shipment of SNAP Fuel to RMDF," North American Rockwell Internal Letter dated 16 March 1973 (2 pages)

Sh64 D. T. Shoop, "Metallographic Preparation of Zirconium Hydride," Atomics International Technical Data Record NAA-SR-MEMO-10145 (June 1964) (7 pages)

Si61 M. T. Simnad and W. P. Wallace, "The Metallurgy of the TRIGA Fuel Elements," Elecktrotechnik und Maschinenbau 78, 581 (1961)

St63 D. H. Stone, "Corrosion Tests of Candidate SNAP 4 Fuel Element Materials," Atomics Intemational Technical Data Record NAA-SR-TDR-8068 (February 1963) (6 pages)

St67* D. W. Staub, "SNAP 10A Summary Report," Atomics Intemational Report NAA-SR-12073 (March 1967) (237 pages)

Sw67 L. D. Swenson, "S8DR Core Performance Evaluation," Atomics International Report NAA-SR12482 (August 1967) (75 pages)

Sw69* L. D. Swenson, "SNAP 8 Development Reactor Nuclear Analysis," Atomics Intemational Report AI-AEC-12864 (October 1969) (83 pages)

Sw69a L. D. Swensen, "Preliminary Computed Fission Gas Release Fraction from NAA-121-1 Fuel Elements," Atomics International Technical Information Document TI-568-24-032 (November 1969) (4 pages)

Sw70 V. A. Swanson, "Neutron Radiography as a Means for Determining H/Zr in SNAP-Type Fuel Elements," Atomics Intemational Technical Information Document TI-568-24-056 (May 1970) (16 pages)

Ta63 H. Taketani, "Hydriding of SNAP 2 Fuel Rods," Atomics International Report NAA-SR-5037 (June 1963) (37 pages)

Ta65 H. Taketani, L. Silverman, and W. L. Korst, "Identification of the Modifier in SNAP Fuel," Atomics International Report NAA-SR-10174 (February 1965) (21 pages)

To61* R. L. Tomlinson, "SNAP Shield Test Experiment Final Hazards Summary," Atomics International Report NAA-SR-5896 (March 1961) (173 pages)

To62* R. L. Tomlinson, R. P. Johnson, and S. G. Wogulis, "SNAP Shield Test Experiment Reactor Physics Tests," Atomics Intemational Report NAA-SR-7368 (July 1962) (35 pages) 
- Tr69 J. Tribfelner, "S8DR Pre-Irradiation Data File and Corresponding Computer Printout," Atomics International Technical Information Document TI-568-24-035 (November 1969) (46 pages)

Tu58 R. R. Turk, "Feasibility Report for Fabrication of SNAP II Fuel Elements," Atomics International Memo NAA-SR-MEMO-3083, Rev. II (October 1958) (32 pages)

Va70 R. Van Houten, "First Status Report (to 5:00 p.m., April 3, 1970) on the Coatings on S8DR Fuel Elements," North American Rockwell Corporation Aerospace and Systems Group Internal Letter dated 7 April 1970 (3 pages)

We85 R. C. Weast, Ed., CRC Handbook of Chemistry and Physics, 66th Edition (CRC Press Inc., Boca Raton, FL, 1985)

Wi58 L. A. Wilson, "Evaluation of Required Fuel Loading in the SER," Atomics International Technical Data Record NAA-SR-MEMO-3406 (December 1958) (12 pages)

Wi59 L. A. Wilson, "SNAP II Experimental Reactor Physics Analysis," Atomics Intemational Report NAA-SR-3607 (June 1959) (71 pages) 


\section{APPENDIX 2 REPORT CONTRIBUTORS}

\section{W. Kneff}

Dr. Kneff is a senior member of the Rocketdyne (and former Atomics Intemational) technical staff who has been at Rockwell for 19 years. He has a background in nuclear physics and has conducted many nuclear measurement and radiation dosimetry experiments in reactors and particle accelerators. He was a contributor to the investigation of self-radiation effects in proposed crystalline high-level waste forms for repository emplacement. Dr. Kneff is a company expert on space power system survivability, and current activities include lethality analyses for theater. missile defense and technical support to ETEC's decontamination and decommissioning development programs.

W. E. Nagel

Mr. Nagel was hired by Atomics Intemational in July 1961 for the specific purpose of establishing a quality engineering and test function for SNAP fuel fabrication. He was made supervisor of the SNAP Fuel Quality Test Unit in January 1962, which he managed until he was assigned as Quality Engineering Manager for all of Al's fuel fabrication in June 1963. In late.1965 Mr. Nagel was reassigned as a research engineer responsible for developing nondestructive test methods for advanced nuclear fuels and in-core components. He was Fuels Quality Engineering Manager again from mid-1967 until 1970, when the S8DR fuel fabrication was complete and he became manager of quality engineering for reactor systems. Mr. Nagel retired in 1991 and was recalled for the present work.

\section{H. Peariman}

Dr. Peariman was Atomics International's Group Leader of Chemistry during the initial SNAP development work, and was in charge of the early work on zirconium hydride. He became Manager of Component Development and (later) the AI Fuels and Materials Division, where he was responsible for fabrication of the first SNAP fuel elements. He retained close association with the SNAP fuel element development and performance activities throughout the active phase of the reactor operation program. Dr. Pearlman also managed the later AI radiation effects investigations on proposed crystalline high-level waste forms. He was recalled from retirement to contribute to the present work.

\section{J. Schaubert}

Mr. Schaubert was part of Atomics International's Nuclear Materials Management Unit during SNAP development, which had primary responsibility for nuclear material control, including procurement, receiving, shipment, intemal transfers, product storage, and accounting records. $\mathrm{He}$ was Manager of the unit beginning in 1968, which included management of the Radioactive Materials Disposal Facility (RMDF). Mr. Schaubert was responsible for shipping all of the spent SNAP fuel to INEL. He is presently retired, and was recalled for participation in the present work. 